Cornell Law Library

Scholarship@Cornell Law: A Digital Repository

Cornell Law Faculty Publications

$12-9-2008$

\title{
Re-Reading Weber in Law and Development: A Critical Intellectual History of "Good Governance" Reform
}

Chantal Thomas

Cornell Law School, chantal-thomas@lawschool.cornell.edu

Follow this and additional works at: http://scholarship.law.cornell.edu/lsrp_papers

Part of the Public Law and Legal Theory Commons

\section{Recommended Citation}

Thomas, Chantal, "Re-Reading Weber in Law and Development: A Critical Intellectual History of "Good Governance" Reform" (2008). Cornell Law Faculty Publications. Paper 118.

http://scholarship.law.cornell.edu/lsrp_papers/118

This Article is brought to you for free and open access by Scholarship@Cornell Law: A Digital Repository. It has been accepted for inclusion in Cornell Law Faculty Publications by an authorized administrator of Scholarship@Cornell Law: A Digital Repository. For more information, please contact jmp8@cornell.edu. 


\title{
CORNELL LAW SCHOOL
}

\section{LeGal Studies ReseArCh PAPER Series}

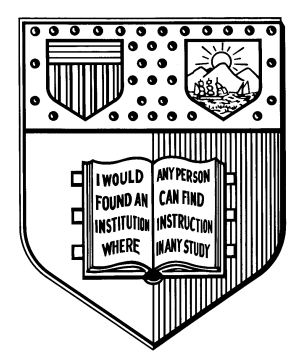

\section{Re-Reading Weber in Law and Development: A Critical Intellectual History of "Good Governance” Reform}

Chantal Thomas

\author{
Cornell Law School \\ Myron Taylor Hall \\ Ithaca, NY 14853-4901
}

Cornell Law School research paper No. 08-034

This paper can be downloaded without charge from:

The Social Science Research Network Electronic Paper Collection:

http://ssrn.com/abstract=1313718 


\title{
RE-READING WEBER IN LAW AND DEVELOPMENT: A CRITICAL INTELLECTUAL History OF “GOOD GOVERNANCE” REFORM
}

\author{
Chantal Thomas*
}

\begin{abstract}
* * *
The "Weberianism" of the modern age derives from the influence of three theoretical concepts in Weber's work. First, Weber described the development of "logically formal rationality" in governance as central to the rise of Western capitalist democracy. Second, Weber posited that Protestant religious ethics had helped to promote certain economic behaviors associated with contemporary capitalism. Third, Weber identified the rise of bureaucratic governance, as the primary means of realizing logically formal rationality, as distinctly modern.
\end{abstract}

This essay examines the influence of these basic insights on discourse on legal reform in developing countries. The prioritization of legal and institutional reforms to achieve "good governance" seems to be part of a larger intellectual shift to the problems and challenges of "governance" in a globalizing world.

Transmitters of Weberian analysis in this milieu, however, have at times elided important nuances in Weber's own thought -- nuances that, if incorporated, might have significant implications within development discourse.

The paper's objectives are: first, to conduct an intellectual history that shows how one of the greatest sociologists influenced an increasingly important area of law reform in the age of globalization; second, to surface critiques arising within that field of law reform; and third, to suggest that there may be some connection between the two. In that sense, the paper seeks to make a contribution to two discourses: to enrich the study of the history of legal thought the reception of an important thinker has shaped contemporary law and policy in a relatively understudied field in the academy; and at the same time to underscore and contextualize policy critiques that have arisen in an increasingly important field of practice.

\footnotetext{
*Professor of Law, Cornell Law School, ct343@cornell.edu. Parts I, II.A. and II.B. were published as Max Weber, Talcott Parsons and the Sociology of Legal Reform: A Reassessment with Implications for Law and Development, 15 MinN. J. INT'L L. 383 (2006). My thanks to Brian Bix, Jim Chen, Daria Roithmayr, Duncan Kennedy and Hani Sayed for their helpful comments, suggestions and encouragements. Errors are of course mine alone.
} 
PART I. Introduction: Weber's Central Insights

Theoretical Insight \#1: “Ideal Types” of Governance .....................................................................10

Theoretical Insight \#2: Protestant Values and the Rise of Capitalism........................................14

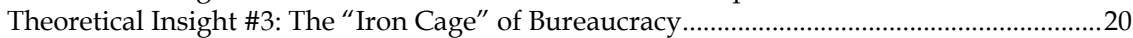

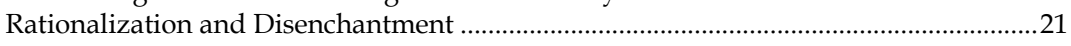

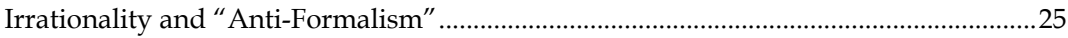

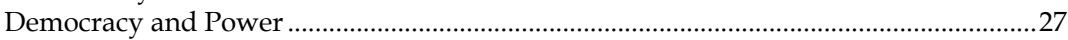

PART II. A Geneaology of Theory, Policy and Praxis: Weber and Development Theorists ......33

A. Talcott Parsons: "Structural Functionalism" as a Precursor to Modernization Theory .......35 A.1. Parsons and Theoretical Shortcut \#1 ("One-Size-Fits-All”):

From "Ideal Types" to "Evolutionary Universals" ..................................................................

A.2. Parsons and Theoretical Shortcut \#2:

The Determinism of "Values" in Modernization.....................................................................45

A.3. Parsons and Theoretical Shortcut \#3:

The Correlation between Modernity and Democracy ........................................................53

A.4. Parsons and U.S. Foreign Policy …………….............................................................6

B. W.W. Rostow: Modernization Theory Meets Economic Development Policy...................65 B.1. Rostow and Theoretical Shortcut \#1 ("One-Size-Fits-All”):

From "Evolutionary Universals" to "Stages of Growth" ....................................................65

B.2. Rostow and Theoretical Shortcut \#2: Modernity and "Values" ...................................69

B.3. Rostow and Theoretical Shortcut \#3: Modernity and Democracy ............................ 70

B.4. Rostovian Modernization Theory and U.S. Foreign Policy ………….........................72

C. Another Path: Moderate Parsonianism in Development Studies..........................................78

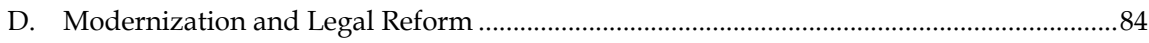

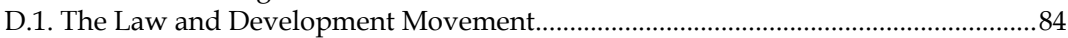

D.2. Another Path: Scholars in Self-Estrangement

from Law and Development's Theoretical Shortcuts..........................................................8

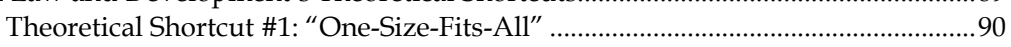

Theoretical Shortcut \#2: The Determinism of Values .................................................93

Theoretical Shortcut \#3: The Correlation between Modernity and Democracy....93

E. The Revival of "Law and Development": The Good Governance Era....................94

The Connection between Weberian Thought and Good Governance Policy ...................97

Theoretical Shortcut \#1: One-Size-Fits-All ..........................................................................98

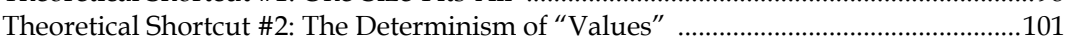

Theoretical Shortcut \#3: The Correlation between Modernity and Democracy............110

PART III. Conclusions and Prospects For Reform. 
The present age and its presentation of itself is dominantly 'Weberian.' ${ }^{1}$

Weber's renowned comparative studies from his Protestant Ethic [The Protestant Ethic and the Spirit of Capitalism] to his Wirtschaft und Gesellschaft [Economy and Society] have yet to be understood in their true light. They are much more than they seem or are generally understood to be, comparative sociological investigations against a background of the history of Western civilization and culture. In a sense which many overlook, they are prophecies and warnings prophecies about the menacing shape of things to come, warnings against the further expansion of the domain of conscienceless reason, even in the name of the most noble ideals... The noblest impulses only too often gave rise to the most baleful consequences. ${ }^{2}$

The "Weberianism" of the modern age derives from the influence of three theoretical concepts in Weber's work. First, Weber described the development of "logically formal rationality" in governance as central to the rise of Western capitalist democracy. Second, Weber posited that Protestant religious ethics had helped to promote certain economic behaviors associated with contemporary capitalism. Third, Weber identified the rise of bureaucratic governance, as the primary means of realizing logically formal rationality, as distinctly modern.

This essay examines the influence of these basic insights on discourse on legal reform in developing countries. Involvement in the politics of his native Germany aside, Weber himself wrote mostly from the perspective of

1 AlASDAir MCINTYRe, AfTER VIRTUE. McIntyre's comment situates Weber within a debate between naturalist and positivist philosophy, which this paper briefly discusses in section A.3. infra.

2 Benjamin Nelson, Discussion on Industrialization and Capitalism, in STAMMER ED., MAX WeBER AND SOCIOLOGY, pp.17-18 (cited in Alan Sica, Rationalization and culture, CAMBRIDGE COMPANION TO WEBER 54, 54 (2000)). 
an historian, seeking to explain the difference between countries rather than to propose reforms for change within them. Though descriptive rather than prescriptive, Weber's analyses have exerted wide-ranging influence on American scholars and administrators who concern themselves with causing developing countries to acquire the affluence of the modern West.

This work originated in the social sciences, and is characterized in particular by the work of Talcott Parsons (with "Structural-Functionalist" sociology) and W.W. Rostow (with "Modernization Theory"), both writing in the mid-twentieth century. Structural-Functionalism and Modernization Theory helped generate a particular set of views, collected under the rubric of "Law and Development Theory" about the kinds of legal reforms necessary to facilitate development, formulated in the 1950s and 1960s. The tenets of Law and Development Theory have in turn helped to shape the basis in the last two decades for a renewed attention within influential development institutions to the importance legal reform referred to as "Good Governance Policy." The prioritization of legal and institutional reforms to achieve "good governance" seems to be part of a larger intellectual shift to the problems and challenges of "governance" in a globalizing world.

Transmitters of Weberian analysis in this milieu, however, have elided important nuances in Weber's own thought -- nuances that, if incorporated, might have significant implications within development discourse. These elisions, which I term the "Three Theoretical Shortcuts," may have contributed to a set of conceptual tendencies that have led to flawed theory and policy on legal reform in developing countries. These tendencies or Theoretical Shortcuts are: an attraction to universalistic, "one-size-fitsall" reform objectives; an emphasis on "values" as a determinant of economic growth and a target of reform 
efforts; and a failure to appreciate the irrationalities that arise endemically out of the bureaucratization of government, as well as the tenuousness of democratic processes therein.

Over the past few decades in the social sciences, a new wave of Weberian scholarship (the "New Weberians") has arisen that seeks to repair some of the distortions in the earlier reception of Weber. $^{3}$ An early and prominent example of this alternative Weberianism arose from the work of three sociologists, Jere Cohen, Lawrence Hazelrigg, and Whitney Pope (hereinafter "Cohen et al."), in a strident 1975 critique of the "Parsonized" understanding of Weber. In "Deparsonizing Weber," Cohen et al. took Parsons to task for downplaying Weber's understanding of power relations in society, as well as Weber's acknowledgment of the importance of material dynamics, in favor of a reading that coincided with classical liberalism's relative neutrality with respect to the role of government, and in favor of an overweening emphasis on "ideals" as a determinant of economic growth. A later strain of alternative Weberian analysis, unlike Cohen et al., accepts the methodological focus on ideals, but seeks to situate the idealist analysis within an appreciation of power relations. This second strain of analysis, reflected for example in the work of Kieran Allen, Sven Eliasson, Nicholas Gane and Peter Lansmann, inherits a sensibility from the line of critical theorists beginning with the Frankfurt school.

At the same time, in the field of development policy, "good governance" policies have come under increasing

3 See, e.g., Peter Lansmann, Power, Politics and Legitimation, in CAMBRIDGE COMPANION TO WeBER 83, 86 (2000): “One obstacle to understanding is the peculiar reception history of Weber's work. Much of post-Second WorldWar social science has worked with a rather simplified and misleading account of Weber's intentions, and often, until very recently, as a result of the incomplete character of translation, with a fragmentary knowledge of his work.

Consequently, Weber's central concepts have frequently been assimilated to the language of the modern social sciences in an uncritical manner." 
scrutiny and criticism by scholars (the "Good Governance Scholars"). In recent years, good governance policy has come under scrutiny from a variety of commentators, whom I dub the Good Governance Scholars: I use this term to include groundbreaking critical thinkers such as James Gathii, Kerry Rittich, and Alvaro Santos, as well as the sophisticated empirical and economic analysis of scholars such as Kevin Davis, Katarina Pistor, and Michael Trebilcock. These Good Governance Scholars have raised a variety of concerns about the efficacy of the prevailing agenda of international "best practices" in legal reform for developing countries.

Though the New Weberians and the Good Governance Scholars appear to be largely mutually unknown, in fact their conclusions often appear to mirror each other. Many of the current policy flaws in good governance reforms as described by the Good Governance Scholars seem to reflect the flaws in the mid-twentieth century reception of Weberian social science as revealed by the New Weberians.

The objective is to define an interface between two bodies of critical reappraisal: that concerning Weber (but not addressing law and development), and that concerning law and development (but not addressing Weber). The sociologists, political scientists and philosophers who have called for a new understanding of Weber have not have considered the impact of their critiques on the field of law and development. At the same time, critics of law and development and governance reforms have perceived shortcomings that track and reflect some of the kinds of conclusions reached by the re-readers of Weber.

This "mirror image" between the respective critiques of the New Weberians and the Good Governance Scholars suggests that there may be a relationship between the flawed transmission of Weberian theory, on the one hand, and some of the programmatic limitations of good governance legal 
reform directives, on the other.

In defining this interface between Good Governance Scholars and New Weberians, this article follows and seeks to merge two trails established by two prior works of legal scholarship: David Trubek's "Max Weber on Law and Capitalism," and Duncan Kennedy's "The Disenchantment of Logically Formal Rationality, or Max Weber's Sociology in the Genealogy of the Contemporary Mode of Western Legal Thought." Trubek's article, written in 1972, explains Weber as an intellectual precursor of contemporary law and development theory; written ahead of the bulk of New Weberian scholarship, it anticipates and briefly engages a critical re-reading of Weber. ${ }^{4}$ Kennedy's article, written in 2004, delves more squarely into the New Weberian project in the humanities and social sciences of critically reassessing the reception of Weberian theory; written as a general exposition of Weber's role in contemporary legal thought, however, it does not apply itself to the problematique of law and development. Inspired by both works, the objective of this paper is to understand how a critical re-reading of Weber might impact on the particular field of law and development.

The point of the paper is not to argue that contemporary law and development policy should seek fidelity to Weberian thought. Rather, the paper's objectives are: first, to conduct an intellectual history that shows how one of the greatest sociologists influenced an increasingly important area of law reform in the age of globalization; second, to surface critiques arising within that field of law

4 See David Trubek, Max Weber on Law and the Rise of Capitalism, 1972 WisCONSIN L. REv. 720, 737 n.31, also discussed below. In Trubek's other canonical law and development essay, David Trubek \& Marc Galanter, Scholars in Self-Estrangement, 1974 Wisconsin L. Rev. 1062, Trubek and his co-author Galanter articulate many of the criticisms whose intellectual history it is the objective of this paper to delineate. See infra, Part II.D., for an explication of the relationship between the criticisms of Trubek \& Galanter and the Theoretical Shortcuts posited by this essay. 
reform; and third, to suggest that there may be some connection between the two. In that sense, the paper seeks to make a contribution to two discourses: to enrich the study of the history of legal thought the reception of an important thinker has shaped contemporary law and policy in a relatively understudied field in the academy; and at the same time to underscore and contextualize policy critiques that have arisen in an increasingly important field of practice.

Part I of the paper provides an Introduction of Weber's best-known analyses - the ideal typology of systems of governance; the association of Calvinist religious values with capitalistic economic growth; and the centrality of bureaucracy. Following the Introduction, this paper will pursue in Part II its project of re-reading Weber against law and development discourse. Part II will describe the trajectory of Weberian analysis from mid-century U.S. social science scholarship to U.S. foreign policies of the same era. In United States scholarship of the twentieth century, Talcott Parsons was arguably the most significant of Weber's interlocutors. Parsons's analysis emerged in a particular moment in mid-century social science in the United States.

Though Parsons embedded his theory in an elaborate methodological framework in an extensive body of scholarship, he also consciously fashioned a theory that sought to influence not only scholarly debates but also the policy and practice of an ascendant foreign-affairs focus in the newly potent United States government. Parsons' theory featured core analytical points which channeled Weber's analysis into a discourse and debate that was distinctly Cold War. Parsons' analysis influenced subsequent writers such as W.W. Rostow, whose own application of the Weber- 
Parsons approach further simplified it for deployment in the foreign-affairs goal of the U.S. to limit the influence of socialist and nationalist politics in developing states. Rostow's analysis in turn shaped the later generation of "good governance" policy, much more separated from scholarship and again much more streamlined in its ideological and practical sources and intended effects. Part II will consider this particular strain of Weberian discourse in the light of other, competing accounts of Weber's work within U.S. social science scholarship.

Finally, Part II will reflect on the significance of the second set of Weberian accounts on the first. In particular, the paper will try to extend these alternative accounts that have arisen within the academy to the law and policy framework of good governance that is the successor of the Parsonized account. In this section, the paper will observe that, for a variety of reasons, this alternative strain of scholarship disconnected from U.S. foreign policy, leaving the field open for the Parsons-Rostow account that ultimately helped to generate, or at least legitimate, contemporary good governance policy. Good governance is highly influential in contemporary law and policy in the international economic order, particularly in the development context. As such, a critical engagement with the intellectual antecedents of the framework takes on not only scholarly significance but also practical and programmatic significance. In Part III, the paper briefly offers some conclusions and suggestions for reform.

Although it begins by recounting the influence of Weberian thought in good governance analysis, this paper's ambitions extend beyond intellectual history. Rather, the paper aims to mount a "legitimation critique" from the platform of this revisionist account. The argument is that good governance analysis, and the law and policy reforms 
that result from it, gain an important source of legitimation in this most influential of modern social theorists. In this sense, critical engagement with the intellectual origins of contemporary good governance analysis generates important implications not only for the concrete programmatic dimensions of good governance law reforms and for the possibility of alternative kinds of approaches to reform, but for their analytical legitimacy.

\section{PART I. Introduction: Weber's Central Insights}

Weber's most influential analyses relating to the role of governance and growth are: (1) the analysis, in Part I of his Economy and Society, of three "ideal types" of rule traditional, charismatic, and "rationalen," with "rationalen" being the type of rule characteristic of modern Western society; (2) the analysis, in The Protestant Ethic and the Spirit of Capitalism, of the way in which religious values supported the development of capitalistic practices in Western Europe, through the association of religious virtue with capitalistic practices such as saving, investment and profit, and having been missing in certain other societies, such as China and India, that attained significant levels of technology but did not undergo industrialization; and (3) the rise of bureaucracy as the expression of both the "disenchantment" modern society inherent in its drive towards rationalization, and its "reenchantment" through the establishment and inculcation of relationships between groups vying for power.

\section{Theoretical Insight \#1: "Ideal Types" of Governance}

Weber in fact was trained as an economist, and so his work which was ultimately deemed a cornerstone of sociology often investigated the social dimensions of 
economic activity. ${ }^{5}$

Weber employed a methodology of "ideal types" in his sociological history, seeking to identify and categorize societies on the basis of an heuristic framework. Though elements of each category were present in every society, Weber believed that such a framework would aid in understanding the distinctive qualities of particular societies as well as their relationship to each other. Particularly influential was Weber's framework of systems of governance $^{6}$ - what Weber called Herrschaft.

In his historical and comparative sociology, Weber sought to explain why "the modern system of industrial (or 'bourgeois') capitalism emerged in Europe, but not other parts of the world... European law had unique features which made it more conductive to capitalism than were the legal systems of other civilizations." 7

5 Richard Swedberg, Max Weber as an Economist and as a Sociologist: Towards a Fuller Understanding of Weber's View of Economics, AMERICAN JOURNAL OF ECONOMICS AND SOCIOLOGY (1999).

6 In employing the term "governance" here, the objective is to use a term that in contemporary English that can describe modes of socially authoritative decisionmaking without necessarily interjecting an explicitly normative sense of whether they are politically valid or desirable. Thus the emerging literature on governance approaches the topic from a range of perspectives: the attempt to categorize and describe neutrally existing systems of governance; the critique of current systems; and the proposal of new systems of governance or improvements in current systems. Weber's own sense of Herrschaft has changed over time, and is one of the foci of recent re-readers, as the section infra indicates.) .

7 David Trubek, Max Weber on Law and the Rise of Capitalism, 1972 WisCONSIN L. REV. 720, 722. Trubek's discussion of Weber remains the authoritative treatment in the American legal academy of the Weberian understanding of the role of law in development. I discovered Trubek's work as a law student, and am indebted to him for showing me that such topics had been and could be successfully incorporated into one's career as a lawyer and legal scholar. Most of the citations that follow in this section refer to Trubek's essay, but Trubek in turn relied primarily on three sources: Max Rheinstein, Introduction, MAX WEBER ON LAW IN ECONOMY AND SOCIETY (M. Rheinstein ed. 1954); REINHARD BENDIX, MAX WEBER, AN INTELLECTUAL PORTRAIT 385-457 (1962); and Weber's essay, “Sociology of Law," which appears in MAX WEBER, ECONOMY AND SOCIETY (G. Roth \& R. Wittich ed. 1968). The advantage of Trubek's treatment is not only that it 
The starting point for this typology was the sense that modern Western governance was characterized by a commitment within its legal systems to the goal of "logically formal rationality." 8 Per David Trubek's fine summary: "Legal thought is rational to the extent that it relies on some justification that transcends the particular case, and is based on existing, unambiguous rules; formal to the extent that the criteria of decision are intrinsic to the legal system; and logical to the extent that rules or principles are consciously constructed by specialized modes of legal thought which rely on ... systematization, and to the extent that decisions of specific cases are reached by processes of specialized deductive logic proceeding from previously established rules or principles." 9

Logically formal rationality in the law aided the tendencies in European society towards capitalistic economic growth in two primary ways. First, it weakened the hold traditional ruling classes on the levers of power, and as such allowed relatively autonomous groups critically, capitalists and workers - to emerge. ${ }^{10}$ Second, it channeled the exercise of legal power into predictable processes and results, thus enabling market actors to rely on contract and property rights to structure their interactions and to achieve greater efficiency therein. ${ }^{11}$

These concepts in Weber's account, written in the early twentieth century, of logically formal rationality and

synthesizes these disparate sources on Weber's sociology of law, but also that it re-orients them in a way readily accessible to a legal, as opposed to a sociological, disciplinary perspective.

9 David Trubek, Max Weber on Law and the Rise of Capitalism, 1972 WisCONSIN L. REV. 720, 730. As Trubek pointed out in that essay, the English common law system constituted an important counterfactual example for Weber's hypothesis. See id.

10 David Trubek, Max Weber on Law and the Rise of Capitalism, 1972 WISCONSIN L. REV. 720, 744.

11 David Trubek, Max Weber on Law and the Rise of Capitalism, 1972 WISCONSIN L. REV. 720, 742-743. 
the rise of capitalism will seem eminently familiar to legal scholars today: they have become touchstones in the field of law and economics. Freedom from interference in legal outcomes by "irrational" sources, whether they be such status-based pressure (what some might describe as a variant of "corruption"), or equitable considerations, has been argued to be central to the ability of market actors to operate efficiently. Predictability, flowing in part from this freedom from interference but also from the commitment to formal rationality, has also been argued to be crucial to efficient market activity.

Thus, according to Weber, " $[\mathrm{T}]$ he rationalization and systematization of the law in general and ... the increasing calculability of the functioning of the legal process in particular, constituted one of the most important conditions for the existence of ... capitalistic enterprise, which cannot do without legal security."12

Logically formal rationality, as a central characteristic of modern Western governance, could be contrasted against modes of governance visible in other societies. The "traditional" mode based its authority on claims to customary or familial status: an "established belief in the sanctity of immemorial traditions and the legitimacy of those exercising authority under them."13 The "charismatic" mode, which based its authority on the claims of a particular ruler to a special authority based on that ruler's extraordinary qualities, ${ }^{14}$ bears a family resemblance to the

12 MAX Weber, ECONOMY AND SOCIETY 883 (G. Roth \& R. Wittich ed. 1968). For a more detailed working out of the relationship see David Trubek, Towards a Social Theory of Law: An Essay on the Study of Law and Politics in Economic Development, YALE L.J.]

13 Max Weber, Economy And Society 215 (G. Roth \& C. Wittich eds. 1968).

14 Weber defined charisma as "the quality of a personality, held to be out of the ordinary (and originally thought to have magical sources, both in the case of the prophets and men who are wise in healing or in law, the leaders of the hunt or heroes in war), on account of which the person is evaluated as being gifted with supernatural or superhuman or at least specifically out of the ordinary powers 
"cult of personality." While every society had elements of all three of these, one could nevertheless categorize societies according to the primacy of one of these modes of governance.

\section{Theoretical Insight \#2: Protestant Values and the Rise of Capitalism}

Weber's essay The Protestant Ethic and the Spirit of Capitalism undoubtedly constitutes his most widely influential concept, reaching beyond the academy to everyday conventional wisdom. Written contemporaneously with a voyage to the United States, ${ }^{15}$ Weber sought to explain why, notwithstanding the general characteristic of "rationalism" in the law amongst European societies, capitalistic behavior had taken root more strongly in some as opposed to others within this group. In particular, Weber sought to explain the reasons why those "districts of highest economic development" were at the same time most amenable to Protestantism and "revolution in the Church."16

Weber rejected the explanation that "the greater participation of Protestants in the positions of ownership and management in modern economic life may... be understood ... simply as a result of the greater material wealth they have inherited." $17 \mathrm{He}$ also rejected as simplistic

not accessible to everybody, and hence as a 'leader.'" MAX WEBER, ECONOMY AND SOCIETY 241 (G. Roth \& C. Wittich eds. 1968).

15 Part One, setting out "The Problem" of greater economic development in Protestant societies and Luther's idea of the calling, was published in 1904 just before Weber's trip to the United States. Part Two, elaborating on the "Practical Ethics of the Ascetic Branches of Protestantism," was published shortly after his return. See John PATRICK Diggins, MAX WEbER: POlitics AND THE SPIRIT OF TRAGEDY 93 (1996); and Diggins more generally for an examination of Weber's views on America.

16 Max Weber, The Protestant Ethic AND the SpIRIT OF CAPITAlism 36 (Talcott Parsons trans., 1930) [hereinafter WEBER, PROTESTANT ETHIC].

17 WeBer, PROTESTANT ETHIC, at p.37. 
the notion that success in capitalism flowed from a "secularization of all ideals through Protestantism."18

Rather, Weber argued that the particular intensity of capitalistic behavior among some - especially Calvinist denominations arose from an alliance of religious virtue, on the one hand, with economic gain, on the other. Within this worldview, economic gain was expressive of religious virtue. As such, the pious individual was obligated by his religious calling to maximize his material gain.

This conceptual shift constituted what Weber called a "reversal" of the "natural relationship":19 "A man does not 'by nature' wish to earn more and more money, but simply to live as he is accustomed to live and to earn as much as is necessary for that purpose." 20 The Protestant ethic of which Weber wrote, however, contradicted this "traditional manner of life" and "traditional rate of profit." 21 In holding that "[e]conomic acquisition is no longer subordinated to man as the means for the satisfaction of his material needs," 22 this shift laid the foundation for instead a "new spirit, the spirit of modern capitalism." 23

The Protestant ethic arose from a foundation of "rationalism" which characterized more generally the trend within European societies. ${ }^{24}$ This rationalism was filtered through Martin Luther's conception of the calling, in which "the valuation of the fulfillment of duty in worldly affairs [w] as the highest form which the moral activity of the individual could assume:" 25 that is, one's religiousity manifested itself in engagement with, rather than "monastic" disassociation from, worldly activity.

18 Weber, Protestant ETHIC, at p.40.

19 Weber, Protestant ETHIC, at p.53.

20 Weber, PROTESTANT ETHIC, at p.60.

21 Weber, Protestant ETHIC, at p.59.

22 Weber, Protestant Ethic, at p.53.

23 Weber, Protestant ETHIC, at p.60.

24 WeBer, Protestant ETHIC, at p.79.

25 Weber, Protestant ETHIC, at p.80. 
According to Weber, Luther's conception of the calling remained "traditionalistic" 26: "The individual should remain ... in the station ... in which God had placed him, and should restrain his worldly activity within the limits imposed by his established station in life." 27 The later Calvinist, Baptist and Methodist denominations within Protestantism would, however, press into new service the notion of worldly activity as indicative of grace: worldly activity now not only manifested one' salvation, but actually proved one's worthiness of being saved. ${ }^{28}$ These perspectives required the individual "methodically to supervise his own state of grace in his own conduct, and thus to penetrate it with asceticism." 29 The notion of asceticism as a prerequisite to salvation required an intense unification and "rationalization of conduct within this

26 WeBER, PROTESTANT ETHIC, at p.85.

27 WeBER, PROTESTANT ETHIC, at p.85.

28 WeBER, PROTESTANT ETHIC, at p.121, discussing the contribution by Calvinism of the "idea of the necessity of proving one's faith in worldly activity." Primary in the development of this approach, according to Weber, was the Calvinist idea of predestination: although at first blush the idea that "some men and angels are predestinated unto everlasting life, and others foreordained to everlasting death," WEBER, PROTESTANT ETHIC, at 100 (quoting the Westminster Confession of 1647), would appear to render moot any possible contributions through one's conduct to salvation or damnation, in fact the doctrine developed into two tenets which would place worldly conduct at the center of salvation: "On the one hand, it is held to be an absolute duty to consider oneself chosen, and to combat all doubts as temptations of the devil, since lack of self-confidence is the result of insufficient faith, hence of imperfect grace... On the other hand, in order to attain that self-confidence intense worldly activity is recommended as the most suitable means." WeBER, Protestant ETHIC, at 111-112. Although Baptism and Methodism rejected the doctrine of predestination, Weber argued that they reached the same endpoint by alternative means: in the case of Methodism, the "aspiration to the higher life... served [] as a sort of makeshift for the doctrine of predestination" WEBER, PROTESTANT ETHIC, at 142-143; in the case of Baptist doctrine, the "immense importance ... attributed by the ... doctrine of salvation to the role of the conscience as the revelation of God to the individual gave... conduct in worldly callings ... the greatest significance for the development of the spirit of capitalism." WeBER, PROTESTANT ETHIC, pp.150-151.

29 Weber, PROTESTANT ETHIC, at 153. 
world... for the sake of the world beyond." 30

This drive to rationalize and unify one's conduct according to ascetic principles lent itself to, and meshed with, the rationalistic emphases of capitalism on the measurement of production for the maximization of gain. Thus, "[t]hat powerful tendency toward uniformity of life, which to-day so immensely aids the ${ }^{31}$ capitalistic interest of the standardization of production, had its ideal foundations in the repudiation of all idolatry of the flesh." 32

The "accumulation of capital" was aided not only by this emphasis on uniform and disciplined conduct, but also at least as importantly by the "ascetic compulsion to save" as a form of abnegation of worldly enjoyment and therefore an indication of grace. ${ }^{33}$ "Waste" was the "deadliest of sins." By contrast, "wealth" was harmful "only ... as a temptation to idleness and sinful enjoyment of life": hence saving and investment indicated both that virtuous industriousness had generated profit, and that virtuous piety had led to the refusal to enjoy that profit in the form of personal consumption. Saving and investment became principal indicatives of virtue, at the same time that they furthered capitalistic ends.

Finally, "Protestant Asceticism" gave a particular moralized underpinning to the emergence of waged workforces employed capitalist entrepreneurs. To begin with, according to Weber ascetic literature generally condoned the "idea that faithful labour, even at low wages, on the part of those whom life offers no other opportunities, is highly pleasing to God" and ultimately "the only means of

\footnotetext{
30 WeBer, Protestant ETHIC, at 155.

31 Weber, Protestant ETHIC, at 157.

32 WeBER, PROTESTANT ETHIC, at 169.

33 WEBER, PROTESTANT ETHIC, at p.172 ("The restraints which were imposed upon the consumption of wealth naturally served to increase it by making possible the productive investment of capital.")
} 
attaining certainty of grace." 34 In addition, Protestantism "legalized the exploitation of this specific willingness to work, in that it also interpreted the employer's business activity as a calling." 35 The pressure imposed by employers upon workers to achieve increasing profits not only failed to offend, but actually furthered, this particular conception of virtue.

Thus, both with respect to the capitalistic labor force and with respect to the capitalistic employer, Protestant Asceticism provided a special motivation: "The emphasis on the ascetic importance of a fixed calling provided an ethical justification of the modern specialized division of labour. In a similar way the providential interpretation of profitmaking justified the activities of the business man." 36

Surrounding the content of this analysis, Weber established several caveats. First, the integration of Protestant Ascetism into capitalistic life was not anything intended by its authors: "the cultural consequences of the Reformation were to a great extent ... unforeseen and even unwished for results of the labours of the reformers. They were often far removed from or even in contradiction to all that they themselves thought to attain." 37

In a second caveat, Weber specifically discouraged an interpretation of his work that privileged religious or cultural values above other causal dynamics of societal change: on the contrary, in view of the "interdependent influences" of "material basis," "forms of social and political organization," and "ideas," it would be "foolish and doctrinaire" to assert that "capitalism... could only have arisen as a result of certain effects of the [Protestant] Reformation." 38 Weber emphasized that is was "not [his]

\footnotetext{
34 Weber, PROTESTANT ETHIC, at 178.

35 Weber, PROTESTANT ETHic at p.178.

36 Weber, PROTESTANT ETHiC at p.163.

37 Weber, PROTESTANT ETHIC at p.90.

38 Weber, PROTESTANT ETHIC at p.91.
} 
aim" to substitute for a one-sided materialistic an equally one-sided spiritualistic causal interpretation of... history." 39 The goal of The Protestant Ethic and the Spirit of Capitalism was, rather, much more modestly to "as far as possible" clarify "what concrete aspects of our capitalistic culture can be traced to" religious movements, keeping in mind the interdependence of material, social, political and ideational "relationships." 40

As a final caveat, Weber argued that, although religious asceticism had helped to give rise to the "spirit of modern capitalism" through its emphasis on "rational conduct on the basis of the calling," 41 the capitalistic system "no longer need[ed] the support of any religious forces." 42 To the contrary, "[s]ince ascetism undertook to remodel the world and work out its ideals in the world, material goods have gained an increasing and finally an inexorable power over the lives of men as at no previous period in history." 43 Weber's view of societal end-point of this trajectory was indeed somewhat gloomy: religious asceticism ultimately gave rise to a dynamic that undermined its own importance in the production of wealth, so that all that remained was the latter. It was in the United States, which had inspired Weber to write The Protestant Ethic, that he saw this dynamic most clearly: "In the field of its highest development, in the United States, the pursuit of wealth, stripped of its religious and ethical meaning, tends to become associated with purely mundane passions, which often actually give it the character of sport." 44

This last point is perhaps most surprising from the point of view of the popular reception of Weberian thought. The

\footnotetext{
39 Weber, PROtestant ETHic at p.183.

40 Weber, Protestant ETHIC at p.91.

41 WEBER, PROTESTANT ETHIC at p.181.

42 Weber, PROTESTANT ETHIC at p.72.

43 Weber, PROTESTANT ETHIC at p.181.

44 Weber, PRotestant ETHic at p.182.
} 
Protestant Ethic and the Spirit of Capitalism did not set out to celebrate either modernism or capitalism. Indeed, Weber ended his study on a decisively somber note:

No one knows ... whether at the end of this tremendous development... there will be a great rebirth of old ideas and ideals, or... mechanized petrification embellished with a sort of convulsive self-importance. For of the last stage of this cultural development, it might well be truly said: 'Specialists without spirit, sensualists without heart; this nullity imagines that it has attained a level of civilization never before achieved.' 45

\section{Theoretical Insight \#3: The "Iron Cage" of Bureaucracy}

The "tragic vision of history" 46 suggested by Weber's gloomy assessment of modern capitalism at the end of The Protestant Ethic is perhaps most expressly elaborated in Weber's writings on the bureaucratization of modern government. Perhaps because Weber's writings on bureaucracy remain somewhat less familiar than his "ideal types" and "protestant ethic" insights, they appear to form his most intricate of observations (this set of insights also seems to prefigure many of the arguments of critical theorists writing later in the twentieth century). ${ }^{47}$ This

45 WEBER, PROTESTANT ETHIC at p.182.

46 John PAtrick Diggins, Max Weber: Politics AND the SPIRIT OF Tragedy 10 (1996) (attributing to Weber a "vision of history, religion, society and politics" that "contains several dimensions of tragedy.") Diggins links this tragic sensibility with Weber's appreciation for the writings of Nietzsche and Simmel, within German philosophy, and also in Weber's knowledge of the "themes of Attic tragedy." See JoHn PAtrick Diggins, MAx Weber: POlitics AND THE SPIRIT OF TRAGEDY 10 (1996). Weber's description also resembles in some ways Durkheim's rendition of anomie in modern life. See Durkheim. 47 See, e.g., Nils GILMAN, MANDARINS OF THE FUTURE 55 (2004) (alluding to how the Frankfurt School employed "Weber's (and Freud's and Nietzsche's) cultural pessimism about an administered world to criticize American mass culture."); Nicholas GANE, MAX WebER AND POSTMODERN THEORY: RATIONALIZATION VERSUS 
theoretical intricacy and relative unfamiliarity means that somewhat more attention will be given here to describing this particular theoretical insight.

\section{Bureaucracy, Rationalization and Disenchantment}

In Economy and Society, Weber identified bureaucratic government - "general rules, hierarchy, full-time training, and so on" 48 - as a central feature of the process of societal rationalization: 49

From a purely technical point of view, a bureaucracy is capable of attaining the highest degree of efficiency, and is in this sense formally the most rational known means of exercising authority over human beings. It is superior to any other form in precision, in stability, in the stringency of its discipline, and in its reliability. It thus makes possible a particularly high degree of calculability of results for the heads of the organization and for those acting in relation to it. It is finally superior both in intensive efficiency and in the scope of its

RE-ENCHANTMENT 81-150 (2002) (demonstrating, inter alia, analytical similarities between Weber's writings on rationalization and re-enchantment, and those of Foucault, Baudrillard and Lyotard); Duncan Kennedy, The Disenchantement of Logically Formal Rationality, or Max Weber's Sociology of Law in the Geneaology of the Contemporary Mode of Western Legal Thought, 55 HASTINGS L.J. 1031, 1076 (2004)

("To a degree that has continually surprised me,... Weber's sociology of law, in conjunction with his general sociology of disenchantment, seems to lead to the conclusion that much critical legal studies work, in the skeptical vein, has been reinvention, or adaptation to view non-Weberian purposes, of Weberian wheels.")

48 Jon Elster, Rationality, Economy and Society, in CAMBRIDGE COMPANION TO WEBER 21, 22 (2000).

49 "This whole process of rationalization in the factory and elsewhere, and especially in the bureaucratic state machine, parallels the centralization of the material implements of organization in the hands of the master. Thus, discipline inexorably takes over ever larger areas as the satisfaction of political and economic needs is increasingly rationalized." Max Rheinstein ed., MAX WEBER ON LAW IN ECONOMY AND SOCIETY 156 (1968) (Edward Shils \& Max Rheinstein trans., 1968). 
operations and is formally capable of application to all kinds of administrative tasks. ${ }^{50}$

Bureaucratization not only grew out of the rationalization process, but constituted the only realistic way of administering the complex societal forms that accompany it. 51 Because "logically formal rationality" in society also accompanies the emergence of capitalism, it follows that bureaucratic administration is ultimately necessary for the preservation of the formally-rational legal system that allows capitalism to thrive. ${ }^{52}$ Indeed, bureaucratization in governance was none other than an application of the same principles of rationality and technological progress that produced industrialization. ${ }^{53}$ Bureaucratic rationality also represents the triumph of "instrumental rationality" 54 over

50 Max Rheinstein ed., MAx WEBER ON LAW IN ECONOMY AND SOCIETY 223 (1968) (Edward Shils \& Max Rheinstein trans., 1968).

51 "The needs of mass administration make it today completely indispensable. The choice is only between bureaucracy and dilettantism in the field of administration." Max Rheinstein ed., MAX WEBER ON LAW IN ECONOMY AND SOCIETY 224 (1968) (Edward Shils \& Max Rheinstein trans., 1968).

$52 \mathrm{Cf}$. "To this extent increasing bureaucratization is a function of the increasing possession of goods used for consumption, and of an increasingly sophisticated technique for fashioning external life--a technique which corresponds to the opportunities provided by such wealth" p.212, Weber, Max. 1946/1958. From Max Weber. Translated and edited by H. H. Gerth and C. Wright Mills.

53 "The decisive reason for the advance of bureaucratic organization has always been its purely technical superiortiy over any other kind of organization. The fully developed bureaucratic mechanism compares with other organizations exactly as does the machine with the nonmechanical modes of organization" p.214, Weber, Max. 1946/1958. From Max Weber. Translated and edited by H. H. Gerth and C. Wright Mills.

54 Jon Elster, Rationality, Economy and Society, in CAMBRIDGE COMPANION TO WEBER, at 21, 23 (2000) ("the substantive rationality of legal and bureaucratic institutions [in Weber's thought' is a form of instrumental adaptation. Whereas individual value-rational action is oriented towards a specific behavior without regard for its consequences..., substantively rational action is guided by its consequences.") 
"value rationality," the latter being Weber's term for

"“conscious belief as a value for its own sake." 55

Bureaucratic governance, "guided by instrumental reason," therefore "lies in stark contrast to non-modern forms" of governance - traditional and charismatic - which confer validity on value-rational grounds. ${ }^{56}$ As a triumph of instrumental rationality, bureaucratization represented modern capitalism's vanquishing of the Protestant Ethic. Whereas Protestant Asceticism at one time provided a justification of certain kinds of rationalistic, maximizing behaviors as ends in themselves, modern capitalism supplanted these justifications with those that valued such behaviors for the maximizations they produced. 57

55 Max Rheinstein ed., MAx WeBER On LAW IN ECONOMY AND SOCIETY 24-25 (1968) (Edward Shils \& Max Rheinstein trans., 1968). As Weber explained in Economy and Society, social behavior could be explained in four possible ways: (1) "instrumentally rational," or consequentialist, grounds; (2) "value-rational" grounds; (3) "effectual" grounds, or "specific affects and feeling states"; or (4) "traditional" grounds, that is, "ingrained habituation." Id. 56 Nicholas GANE, MAx Weber AND POSTMODERN THEORY 25 (2002) (discussing "rationalization and disenchantment" in Weberian theory). "Both of these types of domination are personal rather than impersonal forms of rule, and neither is grounded upon a system of rational law. On the one hand, traditional authority... proceeds 'by virtue of age-old rules and powers' .... On the other, charismatic authority, while based on personal devotion to the leader or hero (prophet), is foreign to rules and proceeds through the repudiation of past authority.... [Both] traditional and charismatic authority .. are orders of authority which demand unlimited personal obligation... [With rationalization] both tend to be replaced by the impersonal rule of the modern (capitalist) bureaucratic state." Gane, at pp.25-26. See also "The appartus (bureaucracy), with its peculiar impersonal character. . . is easily made to work for anybody who knows how to gain control over it. A rationally ordered system of officials continues to function smoothly after the enemy has occupied the area: he merely needs to change the top officials" p.229, Weber, Max. 1946/1958. From Max Weber. Translated and edited by H. H. Gerth and C. Wright Mills. New York: Galaxy. 57 See, e.g., JOHn PATrick Diggins, Max Weber: POlitics AND THE SPIRIT OF TRAGEDY 26 (1996) (describing Weber's theory of capitalism as a "sociological phenomenon springing up originally from religious convictions, which would eventually give way to secularization as the entrepreneur continued to demonstrate his qualifications as a Christian by his business integrity."). 
This was one of the paradoxes that Weber underscored: the way in which the very religious values that helped to propel modern activity in the form of industry in the economic sphere, scientific inquiry, and even the rule of law ultimately created institutions that would destabilize the values that birthed them. In "depicting this movement from God ... to the disenchantment of religious forms," Weber "adheres to a Nietzschean thesis: the highest values devalue themselves." 58

This devaluation of values was what Weber called the "disenchantment" of modern society. In his discussion of "Modernization as Societal Rationalization," Jurgen Habermas quotes a passage of Weber's from a littletranslated essay entitled "Zwischenbetrachtung" or "Religious Rejections of the World and Their Directions":

The rational knowledge to which ethical religiosity had itself appealed followed its own autonomous and innerworldly norms. It fashioned a cosmos of truths which no longer had anything to do with the systematic postulates of a rational religious ethic... On the contrary, rational knowledge had to reject this claim in principle...although the science that created this cosmos seemed unable to answer with certainty the question of its own ultimate presuppositions. ${ }^{59}$

Much as with his analysis of the Protestant Ethic, Weber's theorizing of bureaucracy hardly celebrated

\footnotetext{
58 Nicholas Gane, Max Weber and POSTMOdern TheOry: Rationalization VERSUS Re-ENCHANTMENT 21 (2002) (quoting p.9, Nietzsche, The Will to Power, W. Kaufman trans. (1978)).

59 P.229, Habermas, Theory of Communicative Action, vol.1: Reason and the Rationalization of Society (1984) (Thomas MacCarthy trans.) Thus, Weber showed how disenchantment was hydraulically related to modern processes of analysis with more dynamic methodology than Durkheim's anomie, which identified a similar malaise in modernity, but attributed it to the preeminence of individualism over group identity, rather than to the very means of reasoning within modernity.
} 
modernity. Rather, Weber literally despaired the rise of bureaucratization. In his remarks to a 1901 academic conference in Vienna, Weber exclaimed, "The passion for bureaucracy...is enough to drive one to despair... but what can we oppose to this machinery in order to keep a portion of mankind free from this parceling-out of the soul, from this supreme mastery of the bureaucratic way of life... I only wish to challenge the unquestioning idolization of bureaucracy." 60 Disenchantment resulting from bureaucratization thus constituted one of the "baleful consequences" arising from the "noblest impulses" of modernity. ${ }^{61}$

\section{Bureaucracy, Irrationality and "Anti-Formalism"}

The "baleful consequences" of rationalization and bureaucratization extended beyond the disenchantment of modern life. Indeed, in a turn of analysis reflected by later critical theory, Weber showed how the terrain of a rationalized governance ultimately became susceptible to a peculiarly modern form of irrationality.

This irrationality flows from the very dynamic that generated rationalization, namely the "devaluation of ultimate values." 62 In addition to producing the rationalized world of "stable calculations," rationalization allows for the "emergence of a polytheistic and disordered world of competing values and ideals. For with the rise of modern

60 Remarks, Vienna 1901, Verein für Sozialpolitik, cited in Alan Sica, Rationalization and Culture, in CAMBRIDGE COMPANION TO WEBER 42, 53 (2000). 61 Benjamin Nelson, Discussion on Industrialization and Capitalism, in Stammer ed., Max Weber and Sociology, pp.17-168; cited in Alan Sica, Rationalization and Culture, in CAMBRIDGE COMPANION TO WEBER 42, 54 (quoted above note 2). 62 Nicholas Gane, Max Weber and Postmodern THEORY: Rationalization VERSUS RE-ENCHANTMENT 29 (2002). 
scientific (or 'rational') knowledge, religion is, for the first time, challenged by the disparate claims of other life-orders (Lebensordnungen), the economic, political, aesthetic, erotic and intellectual, which, with the onset of modernity, separate out into relatively autonomous realms." 63 Scientific rationality has both displaced prior ultimate means of assessing values, and failed by its own terms to provide a replacement: the result is that competing non-scientific value systems persist at the same time that they are unable to establish supremacy according to the overarching scientific logic. "The transition to modernity is thus a paradoxical one, for it brings new 'rational' means for controlling and systematizing life while at the same time inaugurating an endless struggle between (and within) opposing valuespheres." 64

This paradoxical tendency towards irrationality surfaces even within the modern legal system, premised on "logically formal rationality." Within the legal system, the proliferation of values resurfaces as the "rise of policy analysis." 65 The devaluation of values destroys the "immanent" quality of law - that is, natural law becomes replaced by positive law. 66 Habermas summarizes the turn to policy: "From the perspective of a formal ethic based on

63 Nicholas Gane, MAX Weber AND POSTMODERN THEORY: RATIONALIZATION VERSUS RE-ENCHANTMENT 29 (2002).

64 Nicholas Gane, Max Weber AND POSTMODERN THEORY: RATIONALIZATION VERSUS RE-ENCHANTMENT 35 (2002).

65 Duncan Kennedy, The Disenchantement of Logically Formal Rationality, or Max Weber's Sociology of Law in the Geneaology of the Contemporary Mode of Western Legal Thought, 55 HASTINGS L.J. 1031, 1071 (2004).

66 "The disappearance of the old natural law conceptions has destroyed all possibility of providing the law with a metaphysical dignity by virtue of its immanent qualities." MAX WEBER, ECONOMY AND SOCIETY 874-875 (G. Roth \& R. Wittich ed. 1968); see also Duncan Kennedy, The Disenchantement of Logically Formal Rationality, or Max Weber's Sociology of Law in the Geneaology of the Contemporary Mode of Western Legal Thought, 55 HASTINGs L.J. 1031, 1066 (2004) ("Positivism becomes the theory of lawmaking because natural law is implausible in theory.") 
general principles, legal norms ... now count as mere conventions that can be considered hypothetically and enacted positively." 67

On the one hand, the demise of "immanent" constraints on lawmaking increased the authority of lawmakers to act as arbiters between "mere" norms. On the other, the modern system expressly turned to lawmakers as the positivist authority for resolving such conflicts. Hence lawmakers, in Weber's understanding of "politics as a vocation," are torn between the "ethics of conviction," in which action was justified on "value-rational" grounds or "immanent norms," and the "ethics of responsibility," in which lawmakers consider the outcomes of their decisions on an instrumentally rational basis that must take into account political "responsibility for the predictable consequences of the action...." 68 This tension is exacerbated, Kennedy writes, by the "dynamism of the capitalist economy [which] generate[s], constantly, increasingly, legal gaps or conflicts involving large economic and political stakes." 69

The result is that the peculiar tendency of irrationality in modern society is reflected in the "anti-formal tendencies of modern law."70 Of modern law, Weber concludes: "In the great majority of its most important provisions, it has been

${ }^{67}$ pp.162-163, Habermas, Theory of Communicative Action vol.1 (1984).

68 P.16, Max Weber, The Methodology of the Social Sciences, ed. \& trans. E.A.

Shils \& H.A. Finch (1949); see also Nicholas GANE, MAx WEBER AND POSTMODERN THEORY: RATIONALIZATION VERSUS RE-ENCHANTMENT 64-69 (2002).

${ }^{69}$ Duncan Kennedy, The Disenchantement of Logically Formal Rationality, or Max Weber's Sociology of Law in the Geneaology of the Contemporary Mode of Western Legal Thought, 55 Hastings L.J. 1031, 1067 (2004).

70 Duncan Kennedy, The Disenchantement of Logically Formal Rationality, or Max Weber's Sociology of Law in the Geneaology of the Contemporary Mode of Western Legal Thought, 55 HASTINGS L.J. 1031, 1064 (2004). 
unmasked all too visibly, as the product of the technical means of a compromise between conflicting interests." 71

\section{Bureaucracy, Democracy and Power}

Weber's conceptualization of conflicting interests in modern life understood politics as a struggle for power. ${ }^{72}$ In opposition to the Marxian view of modern power politics as essentially class-based, Weber argued that power could be measured and distributed according to class, status or party. ${ }^{73}$ Although such struggle could take multiple shapes, Weber nevertheless insisted on an analytical lens that acknowledged the "violence of this struggle and the violence of political power."74 Indeed, Weber defined the state as "that human community which (successfully) lays claim to the monopoly of legitimate physical violence." 75

This perspective demonstrates the influence on Weber's theory of Nietzsche's writings, not only in the analysis of disenchantment as the "devaluation of values"76

71 Max Weber, EcONOMY AND SOCIETY 875 (G. Roth \& R. Wittich ed. 1968); see also Gane at pp.40-41; Duncan Kennedy, The Disenchantement of Logically Formal Rationality, or Max Weber's Sociology of Law in the Geneaology of the Contemporary Mode of Western Legal Thought, 55 Hastings L.J. 1031, 1066 (2004).

72 "The essence of politics is struggle." MAX WEBER, ECONOMY AND SOCIETY 1415, 1450 (G. Roth \& R. Wittich ed. 1968).

${ }^{73}$ From Max Weber: Essays in Sociology, trans. \& ed. H.H. Gerth and C. Wright Mills.

74 Nicholas Gane, Max Weber AND POSTMODERn THEORY: RATIONALIZATION VERSUS RE-ENCHANTMENT 74 (2002).

75 Peter Lansmann, Power, Politics and Legitimation, in CAMBridGe COMPANION TO WEBER 83, 90 (2000).

${ }^{76}$ p.101, Lawrence A. Scaff, Weber on the cultural situation of the modern age, p.99: The coda in Weber on 'specialists without spirit' is Weber's version of those 'last men who invented happiness' pilloried in Nietzsche's prologue to Zarathustra. See Nietzche, at p.10: ("I will speak of the mot contemptible thing; that... is the last man!... 'What is love? What is creation? What is a star?' So asketh the last man and blinketh. The earth hath then become small, and on it there hoppeth the last man who maketh everything small... 'We have discovered happiness,' say the last men and blink...." Thus Spake Zarathustra, Friedrich 
but also in the analysis of governance as power struggle. ${ }^{77}$ Thus, Weber stated in Economy and Society that "without exception every sphere of social action is profoundly influenced by structures of dominancy." 78

Weber declared: "there can ... be no real work in political economy on the basis of optimistic dreams of happiness. Abandon all hope ye who enter here: these words are inscribed above the portals of the unknown future history of mankind."79

The political struggle that Weber analyzed in modern society was subject to two competing dynamics:

bureaucratization, on the one hand, and democratization, on the other.

Bureaucratization reproduced a form of social oligarchy. Due to the large scale of organizational complexity required to govern in modern bureaucracies, power tended to consolidate in hierarchical form favoring technocratic elites. ${ }^{80}$ At the same time, the "leveling of distinctions" based on traditional status in modern society produced a dynamic of democratization. ${ }^{81}$

These two dynamics could produce tendencies in two possible directions: "either 'administering' the mass of

Nietzsche, trans. Thomas Common, 1997.

77 KieRAN AlLEN, Max Weber 7-8 (1998).

78 MAX WeBER, ECONOMY AND SOCIETY 941 (G. Roth \& R. Wittich ed. 1968).

79 Weber, "The National State and Economic Policy" (Inaugural Lecture, Freiburg, May 1895), trans. B. Fowkes, in Reading Weber, ed. K. Tribe (1989) (quoted in Nicholas GANE, MAX WeBER AND POSTMODERN THEORY: RATIONALIZATION VERSUS RE-ENCHANTMENT 166 n.13 (2002)).

80 This observation of Weber's was subsequently developed by his fellow sociologist Robert Michels as an "iron law of oligarchy" in modern societies. Michels, Robert. 1915. Political Parties: A Sociological Study of the Oligarchical Tendencies of Modern Democracy. Translated by Eden Paul and Cedar Paul. ${ }^{81}$ Lawrence A. Scaff, Weber on the Cultural Situation of the Modern Age, in CAMBRIDGE COMPANION TO WeBER 101, 106 (2000). 
citizens deprived of rights and freedoms like a herd of cattle in a bureaucratic 'authoritarian state' with pseudoparliamentarianim, or else including the citizens as participants in the state." 82

Both types of governance - "pseudo-democracy" and "participatory democracy" - were entirely possible outcomes of the modern rationalization process. Indeed, between the two, Weber appeared to believe the former to be the more likely outcome. The threat to democratic governance from modern rationalization stemmed not only from its tendency towards bureaucratic hierarchy, but also from the cultural acclimation of citizens to their role as "little cogs, little men clinging to little jobs and striving toward bigger ones" within the "machinery" of modern bureaucratic capitalism: 83

That the world should know no men but these: it is in such an evolution that we are already caught up, and the great question is, therefore, not how we can promote and hasten it, but what can we oppose to this machinery in order to keep a portion of mankind free from this parceling-out of the soul, from this supreme mastery of the bureaucratic way of life. ${ }^{84}$

In other words, concerted effort was required to maintain even the viability of democratic government in the modern state. Weber clearly viewed modern bureaucratization as both inevitable and in many ways distasteful. Weber also saw democracy as under threat from the modernity's more central feature, bureaucratic rationalization in government.

82 Lawrence A. Scaff, Weber on the Cultural Situation of the Modern Age, in CAMBRIDGE COMPANION TO WeBER 101, 106 (2000). [quoting Weber's Zur Politik im Weltkrieg: Schriften und Redden 1914-1918, or “On Policy during the World War: Writings and Speeches 1914-1918]

83 Weber quoted by J.P. Mayer in Max Weber and German Politics, 2nd. edition. London, Faber and Faber, 1956, pp. 126-127.

84 Weber quoted by J.P. Mayer in Max Weber and German Politics, 2nd. edition. London, Faber and Faber, 1956, pp. 126-127. 
Weber saw this dynamic most clearly in his own country, where the post-Bismarckian state appeared to have choked off real democratic participation. 85

From the foregoing characterizations, one might infer Weber's allegiance to a contractarian set of ideals regarding the normative foundation for democratic governance and the rule of law, and a commitment to the normative egalitarianism found in social contract theorists of the modern state such as John Locke and Jean-Jacques Rousseau. Such an inference would be mistaken, however. Weber does not appear to have shared the focus of these Enlightenment theorists on the normative necessity of universal political liberalism. Sven Eliasson has written that

[Weber] was a liberal in the sense of being deeply concerned about the individual as an autonomous cultural being .... But he did not defend this as an ordinary principle... [and] [i]ndeed he did not think that this was feasible for ordinary people, governed by the necessity of making a living... This was an aristocratic notion of autonomy rather than a principled universalistic one. ${ }^{86}$

This indifference of Weber's to Enlightenment ideals, ${ }^{87}$ and their foundations in the political philosophies of classical

\footnotetext{
85 Sven Eliaeson, Constitutional Ceasarism: Weber's Politics in their German Context, in CAMBRIDGE COMPANION TO WEBER 131, 136 (2000): Weber very much was responding to the political context of German: the danger of domination by the feudalistic Junker class, who were "anti-modernist and backward-looking" and dependent on economic protectionism by the state; the weakness of the bourgeoisie, coupled with their "antipolitical" tendencies ("in part to a long tradition of Romantic skepticism about the Enlightenment, and in part to a sense of impotence resulting from the failure of the liberals to unify Germany in 1848") so that Weber expressed worry about whether "the German bourgeoisie has the maturity ... to be the leading political class"; and dislike of the working class and its journalist leaders who were "poseurs."

86 Eliasson, supra, at 137.

87 Peter Lansmann, Power, Politics and Legitimation, in CAMBridge Companion TO WEBER 83, 88 (2000) (describing the lack of influence of Locke and Rousseau on Weber).
} 
antiquity, ${ }^{88}$ manifested itself, secondly, in a sharply circumscribed understanding even of "real," participatory democracy.

Weber asserted that "[t]rue democracy means... submission to a leader whom the people have elected themselves." 89 Thus, the choice between "participatory democracy" and "pseudo-parliamentary democracy" appeared to boil down to the difference between "a leadership democracy with a "machine" and "a democracy without a leader, which means rule by the "professional politicians.'"90 Thus, Weber played an important role in ensuring that the Weimar constitution allowed the president to be elected directly by the people rather than parliament, ${ }^{91}$ but at the same time held a very limited view of the people's ability to hold the president accountable at any but the most general level. ${ }^{92}$

88 Lansmann, supra, at 91 (describing Weber's rejection of Aristotelian classifications of government in favor of his own "command"-based typology).

89 Kieran Allen, Max Weber 171 (1998) (quoting Beetham, Max Weber and the Theory of Modern Politics, p.236).

90 P.142:, citing Landesmann \& Ronald Spiers ed., Political Writings (1994), at 351. This quote resembles that from Eliasson p.106 cited above.

91 Article 41 of the Weimar Constitution.

92 Hence the following recorded exchange between the reactionary General Ludendorff and Weber: "Ludendorff: What is your idea of a democracy, then? Weber: In a democracy the people choose a leader whom they trust. Then the chosen man says, "Now shut your mouths and obey me. The people and the parties are no longer free to interfere in the leader's business." The exchange between Weber and Lufendorff, according to Eliasson, came at the end of the World War I when Weber was trying to convince Lufendorff to "give himself up to the Allies." Id. At 146. After the quoted passage above, "Weber added that thereafter the people can rule and say "to the gallows with the leader.'" Id. At 147. Nevertheless, Weber's endorsement of "leadership democracy" generated strong criticism after World War II, particularly in Wolfgang Mommsen's charge that Weber's theory served "to make the German people inwardly willing to acclaim Adolf Hitler's leadership position." Id. At 144 (quoting Mommsen, Max Weber and German Politics (1959) at 410). Although Weber died in 1920, his express opposition during his lifetime to anti-Semitism and to racism, as well as his defense of academic freedom, suggests that he would have opposed Nazism. See John PATrick Diggins, MAx Weber: Politics AND THE SPIRIT OF TRAGEDY 271 (1996). Nevertheless, Weber undoubtedly left some ambiguity as to the 
Thus, Weber's understanding of democracy stemmed from a pragmatic, rather than a normative, orientation. Weber saw democracy - at the aforementioned "plebiscitary" level as necessary to break the chokehold of the landholding interests who were stalling Germany's capitalist economic growth. Democracy, Weber, believed, could help to mobilize Germany's relatively weak bourgeoisie. ${ }^{93}$ In this sense, democracy in Germany's particular context could help to propel capitalism. The converse relationship - that capitalism would automatically give rise to democracy - was not a Weberian hypothesis. Moreover, the relationship between democracy and economic growth that Weber desired would not naturally arise but rather had to be pursued through concerted reform.

relationship between popular accountability and "leadership democracy."

For example, in addition to Article 41 enabling direct presidential elections, Weber also supported Article 48 of the Weimar constitution, which "granted the president extraordinary powers in times of crisis," although Weber's role in relation to Article 48 is a matter of dispute while his role in promoting Article 41 is accepted knowledge." Sven Eliasson, Constitutional Caesarism, at p.142. Though Weber himself did not expressly resolve the ambiguous relationship between popular election and extraordinary presidential power, one "author who devoted much of his thought to resolving the constitutional ambiguities that Weber bequeathed to German posterity was Carl Schmitt." Id. At. 147. Schmitt foresaw that "Weimar parliamentarianism could not withstand" the a "totalizing party" such as the National Socialists. "The presidential leader, Hindenburg, came to a parallel conclusion, and used Article 48 to install Hitler in power. Schmitt, in short, filled the lacunae in Weber's constitutional thinking. How Weber himself might have filled it will," according to Eliasson, "forever remain unclear." Id. At 147. For a thorough exposition and critique of Schmitt's constitutional thought, see Oren Gross, The Normless and Exceptionless Exception: Carl Schmitt's Theory of Emergency Powers and the "NormException" Dichotomy, 21 CARDOZO L. REv. 1824 (1999-2000).

One final clue perhaps lies in Weber's somewhat surprising support for a "strong parliament" as a corrective "to balance the power of the bureaucracy." Id. At p.142. Weber appears, therefore and contrary to his own dichotomous phrasing, to have supported both "parliamentarian democracy and plebiscitary rule." Id. At 143. The best explanation for this, according to Eliasson, is that Weber "envisioned balance, much like in a monarchical system." Id. At 143. ${ }^{93}$ See Chapter 2 in Kieran AlLEN, Max Weber (1998). 


\section{PART II. A Geneaology of Theory, Policy and Praxis: Weber and Development Theorists}

There are three key moves that get made in the transition from Weber's own insights to the truths of development policy. The first two, relatively explicit, moves are: (1) the move from an inductively based set of ideal types of society to an a priori belief in a single evolutionary path for all societies, ending in Western-style capitalist democracy; (2) the move from identifying the importance of the normative dimension of economic practices to a belief in the primacy of "values" in economic practices.

The third move is more subtle, and indeed consists mostly of analytical evasion rather than assertion. This is the idea that democratic governance goes hand-in-hand with capitalistic economic growth - more simplistically put, the notion that markets and democracies are mutually reinforcing components of the same evolutionary process.

In fact, all three of these moves were reflected in significant elisions by Parsons of Weber's own theoretical premises. These elisions (which I will call "the Three Theoretical Shortcuts") can be summarized as follows: (1) First, Weber himself repeatedly sought to resist the temptation to induce a rigid, universalistic framework, preferring to understand his typology as primarily heuristic; however, Parsons employed Weberian theory to establish a universal model of societal evolution (the "One-Size-FitsAll" Theoretical Shortcut). (2) Second, far from rejecting the "materialist" analysis of Marx and others, Weber insisted on the additionally important role of ideational frameworks and saw the interaction between these two as explanatorily essential; however, Parsons saw values as essentially dispositive of social identity and social change (the 
"Determinism of Values" Theoretical Shortcut). (3) Weber's own his understanding was that democratic governance was both necessary and significantly limited in its emancipatory potential by the power dynamics inherent in bureaucratization; Parsons, however, assumed an unproblematic correlaton beween institutional rationalization in modernity, on the one, and democracy, on the other (the "Correlation of Modernity with Democracy" Theoretical Shortcut).

This geneaology follows the role of Weber in Parsonian theory, with its accompanying Theoretical Shortcuts, through to policy on law and development in particular. At key moments, a symbiotic relationship arose between leading scholars of modernization and policymakers within the foreign affairs related branches of the U.S. government. At those moments, ideas developed within the academy took root and helped provide a basis for U.S. policy. It is those moments within the academy, and their transmittal to U.S. policy, that this section focuses on.

Through some interaction of these dynamics, all of these thinkers display the same tendencies in reading Weber: an attraction to a universal model of growth and development, an emphasis on normative rather than nonnormative interests and an alliance of the normative with the "expanding capitalist nucleus" idea, and a glossing-over of the role of democracy.

This section will trace this geneaology. The first part of this section will trace the three "elisions" of Weberian theory -- the emphasis on normative over non-normative factors, the emphasis on universals, and the superficial association of market growth with democratic governance from Parsons into modernization theory. The section will also highlight the intersections between economic and sociological theory on the one hand, and development policy discourse in the context of U.S. governmental practice on the 
other.

\section{A. Talcott Parsons: "Structural Functionalism" as a Precursor to Modernization Theory}

Talcott Parsons is widely understood to have been the most influential United States sociologist of the twentieth century. ${ }^{94}$ Parsons was also an influential advocate for Weberian theory in the U.S. scene, translating both The Protestant Ethic and Economy and Society into English.95 Parsons's advocacy included his inspirations by Weber in formulating his distinctive brand of sociological theory, which ultimately became known as "structuralfunctionalist" theory. ${ }^{96}$ Finally, Parsons also sought to connect some of his theoretical conclusions to U.S. foreign policy, playing an active advisory role from the 1930s to the 1950s as the U.S. developed its approach towards newly decolonizing states.

The result of these combining factors was Parsonian influence in the ensuring the importance of Weberian thought in development theory, policy and praxis in the mid-to-late twentieth-century United States - and also in ensuring the reception of Weberian thought in a particular form. The next sections will seek to demonstrate how the three theoretical influences described above arose in Parsons' own theory, and how they replicated themselves throughout the development discourse of this era.

94 Peter Hamilton, TAlcott Parsons 13 (1983). “Looking at the development of American sociology over the past fifty years, one is immediately struck by the scale of the contribution Talcott Parsons made... Parsons reformulated the nature of sociological inquiry... and ... gave it ... a theoretical programme, which it lacked before."

95

96 Though structural-functionalism had fallen from grace by the 1970s, at its peak the approach enjoyed status widespread influence within sociological theory. 
A.1. Parsons and Theoretical Shortcut \#1 ("One-Size-FitsAll"): From "Ideal Types" to "Evolutionary Universals"

Parsons is often credited as being concerned above all with building a "general" theory of social action as a foundation for sociological analysis. Parsons' first step towards this end occurred in his work The Structure of Social Action. The first step in Parsons' own universalist analysis, however, was an extrapolation of "generalized"97 and "systematic" theoretical precepts from Weber's analysis of "ideal types." Parsons was careful to establish that Weber himself shied away from "systematic" analysis, ensuring that the systematization of Weber's analysis was identifiable as Parsons' unique improvement.

Before setting forth a systematic theory, Parsons devoted some time to delineating the lack of systematic analysis in Weber, 98 much of which was intentional on Weber's part. Parsons observed Weber's opposition to the idealistic or intuitionist strain of German theory. ${ }^{99}$ By contrast, Weber sought to embrace an inductive, and ultimately empirical, approach. ${ }^{100}$ Parsons gives a careful account of Weber's balancing of the commitment to identifying general principles with the awareness of the limitations of those principles:

A general ideal type is such a construction of a hypothetical course of events with two other characteristics: (1) abstract generality and (2) the idealtypical exaggeration of empirical reality. Without the first of these last two elements, the concept might be

97 Parsons, Structure of Social Action, at p.601; id. At p.640.

98 See Parsons, Structure of Social action, at pp.601-641.

99 Parsons, Structure of Social Action, at p.602.

100 Parsons, Structure of Social Action, at p.602 ("Weber throughout emphasized that scientific concepts do not exhaust concrete reality but involve selection and are hence in this sense unreal."). 
applicable only to a single historical situation; without the second it might be merely a common trait or a statistical average. ${ }^{101}$

Although Weber's analysis of ideal types seemed to embody universalizable implications, Weber himself stopped short of making those explicit. It was left to Parsons to clarify the relationship of the "universal to the particular" in Weber's analysis. ${ }^{102}$ In doing so, Parsons declared it "necessary, in order to clarify the implications of his position, to go beyond Weber's own analysis."103

In The Structure of Social Action, Parsons sought to build a more "systematic classification of ideal types."104 In doing so, Parsons introduced his own "generalized theoretical account" of society under a "structural" analysis of "systems of action" and "systems of elements." 105 Indeed, Parsons' desire to construct a "total, general theoretical system" 106 would irritate many of his contemporaries. ${ }^{107}$ The irritation may have become further inflamed by Parsons' own rather abstruse language, ${ }^{108}$ requiring several iterations

101 Parsons, Structure of Social Action, at p.605-606.

102 Parsons, Structure of Social Action, at p.614.

103 Parsons, Structure of Social Action, at p.614.

104 Parsons, Structure of Social Action, at p.640.

105 Parsons, Structure of Social Action, at p.640.

106 "Parsons has stood virtually alone in his concern with the construction of a total, general theoretical system." Edward C. Devereux, Jr., Parsons' Sociological Theory, in The Social Theories of TAlCott PARSONS: A CRITICAL EXAMINATION 1, 1 (1961).

107 "In his Dedication of The Social System, Talcott Parsons describes himself as an incurable theorist. On this point even his severest critics would hasten to agree. Certainly he has done a great deal more theorizing than any other contemporary American sociologist; and it is probably also true that he has done rather less of anything else." See Devereux, supra, at 1. The philosopher Max Black derided Parsons' theories as tending towards "aphorisms" such as "Whenever you do anything, you're trying to get something done." See Devereux, supra, at 279 (quoting Max Black, Some Questions About Parsons' Theories, p.268.). 108 "Parsons has been explaining his own theories in his own words these many years, but the evidence is rather impressive that he has not always succeeded in making himself understood." See Devereux, supra, at 1-2. 
both by the author himself ${ }^{109}$ and by commentators to gel into the influential "structural-functional" sociological theory of social action.

Methodologically, Parsons' "structural-functionalist" theory straddled German and Anglo-Saxon theory, 110 seeking to blend the sought to blend the "analytical elegance" and dynamism of economics, with both the concreteness of positivists and the sensitivity to culture of idealists. ${ }^{111}$ Thus, Parsons sought a transhistorical, general "analytical theory"112 of society that was both dynamic and

109 See Chandler Morse, The Functional Imperatives, THE SOCIAL THEORIES OF TALCOTT PARSONS: A CRITICAL EXAMINATION 100, 113 (1961). “The relation of structure to process was far from clear in early versions of the Parsonian model. But as the model evolved, the relationship acquired an increasingly definite form." Id.

110 See Devereux, supra, at 2,4,5.

111 Parsons goal was to combine: Combine the "analytical elegance" and the "action frame of reference" of economists (while rejecting their focus on rationality), the focus on "physiological parameters of personality and human behavior" of the positivists, while rejecting its elements of "mechanistic determination," and from the idealists the "analysis of cultural configurations and of the role of ideas, values, and norms" without the "cultural relativism which... blocked general theory." See Devereux, supra, at 19.

112 Feraro explains the Parsonian understanding of the term: "The structural type of [conceptual] scheme specifies concepts that refer to the types of units or parts and the relations among them that constitute the generic structure of a category of empirical system within the scope of a theoretical framework. The corresponding general propositions are statements of uniformities in the behavior of concrete parts and relations, as these are conceptualized. Parsons calls such general propositions empirical generalizations. The analytical type of [conceptual] scheme specifies analytical elements or variables, the values of which characterize concrete components of the empirical system. The corresponding general propositions are statements of uniformities in the analytical relationships among such elements. Parsons calls them analytical laws. An analytical theory, finally, is a system of analytical laws. One important implication of these distinctions is that the formulation of an analytical theory must be based upon an accompanying structural type of conceptual scheme as well as an analytical type. The reason for this

is that an analytical law presupposes elements that characterize the various components or concrete entities comprising an empirical system and these components have to be conceptualized in structural terms (i. e., in terms of ideas about the types of concrete units and their relations). It is because of this methodological implication that Parsons exerts so much effort in his early work 
responsive to culture.

Within this structural account, Parsons emphasized the importance of methodological dynamism, as expressed on two different levels: first, the fundamental unit of analysis was the "unit act," 113 and the sociological theory itself was a theory of social action.114 Second, Parsons embraced a "voluntaristic theory of action," which assumed a critical role of agency in determining how individuals committed "unit acts" against the complex backdrop of his structural-functional analytical framework. ${ }^{115}$

Parsons posited that social action occurred against a backdrop of structural, universal features of the social system. ${ }^{116}$ The three fundamental structural sub-systems were: "the personality systems of ... individualized actors"; 117 the differentiation and organization of social

to provide a general conception of the structure of empirical social action systems that can become the basis for a later analytical sociological theory of these systems." THOMAS J. FARARO, SOCIAL ACTION SYSTEMS : FOUNDATION AND SYNTHESIS IN SOCIOLOGICAL THEORY 82 (2001).

113 THOMAS J. FARARO, SOCIAL ACTION SYSTEMS : FOUNDATION AND SYNTHESIS IN SOCIOLOGICAL THEORY 88-93 (2001). The "unit act" was defined to include the following elements: an actor; an "end" (that is, "a future state of affairs toward which the process ofaction is oriented,"; a "situation," "differing from that to which action is oriented (the end) and including two elements, those which cannot be altered by the actor - conditions - and those which he can control means); and a "specific mode of relationship between the elements of the unit act, so that 'in the choice of alterative means to the end insofar as the situation allows alternatives, here is a 'normative orientation' of action.'" PETER HAMILTON, TALCOTT PARSONS 70 (1983) (quoting Talcott Parsons, Structure of Social Action at p.44).

114 E.g., Parsons' landmark work, The Structure of Social Action (1937); Parsons, Working Papers in the Theory of Action (1953).

115 See Parsons, The Structure of Social Action (1937); Parsons, The Social System (1951).

THOMAS J. FARARO, SOCIAL ACTION SYSTEMS : FOUNDATION AND SYNTHESIS IN SOCIOLOGICAL THEORY 87 (2001).

116 "Structure, as Parsons sees it, represents at best a convenient way of codifying and talking about certain apparent consistencies in social phenomena... [but in order to avoid reification we must employ the] conception of dynamic equilibrium." See Devereux, supra, at 53.

117 "the personality systems of ... individualized actors, consisting of internalized 
role; 118 and "the culture system."119 Of these three interdependent sub-systems, Parsons saw culture as the most dispositive. ${ }^{120}$

In The Social System (1951) and Toward a General Theory of Action (1951), Parsons developed the "functionalist" side of his methodology. In addition to taking place against this structural backdrop, he now asserted, social action was directed by a set of four "functional imperatives," or 'problems' which must be met adequately if equilibrium and/or continuing existence of the system is to be maintained."121

The four problems are those of Goal Attainment, or "keeping the action system moving steadily toward its goals"; Adaptation, or "properly perceiving and rationally manipulating the object world for the attainment of ends"; Integration, or "holding cooperating units in line, of creating and maintaining 'solidarity,' despite the emotional strains involved in the process of goal attainment"; and Latency, or ensuring that "units have the time and the facilities, within a suitable conditioning environment, to constitute or reconstitute the capacities needed by the system." 122

These imperative problems at the societal level create social sub-systems, each to address the respective basic

\footnotetext{
'need dispositions' and therefore of potential 'motivational commitments' to various types of goals and to various patterns of behavior." See Morse, supra, at 105.

118 "The social system, or structure of social organization, consisting of defined roles and their associated and institutionalized (=internalized and shared) roleexpectations (= 'expected performances' and 'sanctions.')" See Morse, supra, at 105.

119 "The culture system, consisting of the heritage of knowledge, beliefs, ideas, technologies, mores, customs, habits, laws, values, standards, norms, together with the symbols, both tangible (artifacts) and intangible (language, the arts) that represent them." See Morse, supra, at 105.

120 "No one of these systems is entirely independent of the others. The culture system is the major binding element." See Morse, supra, at 105.

${ }^{121}$ See Morse, supra, at 113.

122 See Morse, supra, at 113-114.
} 
functional imperative: Goal Attainment manifests, for example, in the political system; Adaptation manifests in the economic system. ${ }^{123}$ Each sub-system can further be analyzed in terms of these functional imperatives: for example, the economy can be analyzed in terms of Goal Attainment (the "Production sub-system"); Adaptation (the "Investment capitalization sub-system"); Integration (the "Entrepreneurial sub-system"); and Latency (the "Economic commitments sub-system").124

Social action was determined within the structural framework of personality-social role-culture; and driven by the functional imperatives of goal attainment-adaptationintegration-latency. Parsons' last major theoretical contribution was to posit that social action was additionally mediated according to a set of five fundamental "pattern variables" for interpreting the social situation, mediating potentially conflicting concepts, and producing the ultimate social orientation in which action occurred. ${ }^{125}$

The functional imperatives are transhistorical and

\footnotetext{
123 See Morse, supra, at 121-122.

124 See Morse, supra, at 140-141.

125 See Devereux, supra, at 38-42. The framework for structural analysis are the pattern variables, guided by three principal criteria: "First, the variables should be completely general and permit comparisons between groups of any sort whatever and across cultures... Second, the variables should be relevant for the action frame of references... Finally, the variables should be relevant for the analysis of the functional problems about which system differentiation takes place... The outcome of Parsons' thinking about these matters was the nowfamous set of pattern variables... These were a set of five dichotomous variables conceived as constituting universal and basic dilemmas confronting any actor in any social situation. Parsons argued that each variable represented a fundamental problem of orientation which the actor would somehow have to resolve either one way or the other; moreover, he would have to come to terms with all five before arriving at any determinate orientation.... 1. Affectivity [e.g. marital bond] -Affective neutrality [e.g. customer bond]...; 2.Specificity [customer] -diffuseness [marital]...; 3. Universalism [cognitive]-particularism [cathectic]...; 4. quality-performance...; 5. self-orientation-collectivityorientation...."
} 
universal, and the social response to them is evolutionary in nature: societies evolve towards ever-higher levels of structural "differentiation" in the management of social roles. ${ }^{126}$ Although Parsons' theory was universalist in that it posited that all societies would traverse roughly the same set of structural-functional changes, this progress was far from inevitable. In fact, societies could fail to progress if their cultures did not adapt sufficiently to environmental conditions ${ }^{127}$ : the term evolution implied a race for survival of the fittest among societies and cultures. Hence Parsons' theory of "evolutionary universals": adaptations universally required in order for societies to progress to modernity. ${ }^{128}$

This neo-Darwinian, (or more accurately, neoSpencerian), ${ }^{129}$ perspective also implied the urgency of policy intervention for those societies that had to date failed to produce the requisite cultural change for economic development. As one Parsonian remarked, "There ought to be interest also in the application of evolutionary theory to the practical problem of modernization: without economic and social development some considerable proportion of the ... persons on the planet have a bleak future."130

126 See Morse, supra, at 143: "These four functional problems represent four distinct (yet interdependent) social 'ends,' and constitute the basis of four corresponding rationalities, the simultaneous application of which is responsible for the ways in which social systems function. Within a rather undifferentiated social system, such as a primitive family or tribe, consistency among the four rationalities and their application is achieved by the institutionalization of role patterns together with the opportunity for adjustment by direct settlement of conflicts.... When a society becomes highly differentiated, the possibilities of inconsistency become far more numerous... The degree of consistency achieved is a determinant of the stability or instability of the system, any inconsistency among the four types of rationality or their application being a particularly important source of conflict and, potentially, of change."

127

128

129 For a discussion of Herbert Spencer and social Darwinism, see Chantal Thomas, Globalization and the Reproduction of Hierarchy, UC Davis Law Review.

130 Jackson Toby, Parsons' Theory of Societal Evolution, in TALCOTT PARSONS, THE 
Parsons' reading of Weber's The Protestant Ethic through his own structural-functionalist lens helped him to conclude from this theory that "American society constituted an evolutionary breakthrough; it displayed a higher level of organized complexity than any other."131 It was at this stage that Parsons' methodology reached its zenith, ${ }^{132}$ disseminating through Parsons-trained academic appointees to the rapidly expanding field of sociology from the 1930s to the 1960s. ${ }^{133}$

In one highly influential application of the pattern variable analysis, Parsons working with his frequent collaborator Edward Shils, further streamlined the "pattern variables" into a general division between "traditional" and "modern" society. 134 The dualistic distinction between tradition, on the one hand, and modernity on the other, would be picked up by W.W. Rostow ${ }^{135}$ and employed generally in the development policy of the time. Thus, Parsons' work helped to establish the groundwork for modernization theory. In his drive to develop a universalistic account of economic growth and its relationship to governance, however, Parsons explicitly elided those aspects of Weber that contradicted this objective. ${ }^{136}$

EVOLUTION OF SOCIETIES 1, 20 (1977).

131 Frank J. Lechner, "Talcott Parsons," in WiLliam H. SWATOS, JR. EdITOR, ENCYCLOPEDIA OF RELIGION AND SOCIETY (1998).

132 Peter Hamilton, TAlcott Parsons 28 (1983). (“The influence exerted by

Parsons's theoretical work over American sociology ... cannot be overestimated. Within the general context of sociological orthodoxy at the time, normally referred to as structural-functionalism, Parsons reigned supreme.")

133 Peter Hamilton, Talcott Parsons 28 (1983).

134 Talcott Parsons and Edward A. Shils, eds., Toward a General Theory of Action

(Cambridge: Harvard University Press, 1951).

135 Walt Whitman Rostow, Review of "Toward a General Theory of Action," 5

World

Politics 540 (1953).

136 Parsons describes these himself in The Structure of Social Action (1949, p.v-vi). In the introduction to Structure of Social Action, he notes that he is not interested 
Parsons believed that his general theory essentially extended and perfected the insights of Weber's theory of ideal types. Parsons asserts that "if Weber had developed such a systematized general theory, "he could hardly have failed' to realize that functionalism represents the most viable approach." 137 Subsequently, however, New Weberians have demonstrated the ways in which Parsonian universalism not only misapplied Weber's typology but, more seriously, misunderstood Weber's overarching project. In "Deparsonizing Weber," for example, Cohen et al. strongly opposed Parson's reading of Weber as a nascent functionalist, arguing that Weber himself "rejected functionalism."138 They argued that Parsons dramatically simplified Weber's analysis (criticizing Parsons for treating a factor as "decisive rather than ... one of several important considerations."139 This simplification would have formed the ground floor in the one size fits all edifice.

\section{A.2. Parsons and Theoretical Shortcut \#2: The Determinism of "Values" in Modernization}

In The Structure of Social Action, Parsons argued that Weber and other prominent social theorists had converged on the centrality of "cultural norms and beliefs - in other

\footnotetext{
in the "separate and discrete propositions to be found in the works of" the authors he considers (primarily Weber, Durkheim, Alfred Marshall and Vilfred Pareto), but in "a single body of systematic theoretical reasoning the development of which can be traced through a critical analysis of writings of this group and of their predecessors." The Structure of Social Action (1949, p.v) This amounts to an admission that these writers are being read for the ways in which they support a theory that Parsons himself wishes to develop.

${ }_{137}$ COHEN p.230, citing Talcott Parsons, Introduction to Max Weber, The Theory of Social and Economic Organization 28-29 (1947) (A.M.Henderson and Talcott Parsons trans.) 138 MAX WEBER, ECONOMY AND SOCIETY 13-15, 17-18 (G. Roth \& R. Wittich ed. 1968). 139 (COHEN p.230).
} 
words, values" as an explanation for social action. ${ }^{140}$ While the "conditions of action" and other environmental factors played an important role in determining social evolution, culture was the ultimate cause. ${ }^{141}$

Defenders of Parsons were careful to point out that Parsons' structural-functionalist theory did not focus on beliefs to the exclusion of other factors. ${ }^{142}$ Yet Parsons himself described his work as "culturally determinist."143 Although the "institutionalization of values" was "a contingent process," the "normative pattern" of those values provided "a society its identity" as the "single most important functional[ist] facet." 144 As Parsons argued, the "concept of values provides the focal center for analyzing the organization of [social] systems, of societies and of personalities." 145

It was Parsons' theory that influenced writers such as David McLelland to focus on the "achievement motive" in culture as an explanation for effective social adaptation. ${ }^{146}$

140 NiLs Gilman, MANDARins OF THE Future 74 (2004).

141 Jackson Toby, Parsons' Theory of Societal Evolution, in TALCOTT PARSONS, THE EVOLUTION OF SOCIETIES, at 1, 8 (1977) (these other factors did "not give direction to change; direction is given by cultural values") (emphasis in original). Thus, for example, "Parsons explains the ultimate failure of the Roman Empire in terms of the inability 'to develop a dynamic religious system which could legitimate and strengthen the enormously expanded societal community'." Jackson Toby, Parsons' Theory of Societal Evolution, in Talcott Parsons, The Evolution of Societies, at 1, 9 (1977) (citing Talcott Parsons, Societies:

Evolutionary and Comparative Perspectives, at 92 (1966)).

142 Jackson Toby, Parsons' Theory of Societal Evolution, in TALCOTT PARSONS, THE EvOlution OF SOCIETIES, at 1, 8 (1977) (asserting that Parsons' version of cultural determinism "does not mean that cultural developments are the only or even the main source of social change." Toby specifically wanted to distinguish Parsons from the more exclusively cultural explanations of theorists such as Ruth Benedict. See Toby, supra, at 9; see also Ruth BenEdict, PATTERns OF CUltural CHANGE (1934).

143 TAlCott Parsons, SOCIETIES: Evolutionary AND Comparative PersPeCtives, at 113 (1966).

144 Lechner, supra.

145 Quoted in Nils GILMAN, MANDARINS OF THE FutURE 82 (2004).

146 See David McLelland, The Achievement Motive (citing Parsons). 
Parsons' theory of culture and social change also posited a universalistic theory of societal evolution in a "sequence of stages" 147 - a characteristic that would surface fully in one of Parsons' most important intellectual heirs, W.W. Rostow.

Certainly, Weber saw himself and his work as opposed to the economic determinism of what is sometimes termed "vulgar" Marxism. ${ }^{148}$ At the same time, however, New Weberian scholars have emphasized that Weber also accepted much of the fundamental wisdom of Marx's approach. That is to say, Weber's theory both diverged and converged with Marxian analysis. ${ }^{149}$

The clearest example of Weber's careful blending of historical materialist insights with his own analysis might be his well-known statement that "very frequently the "world images' that have been created by 'ideas' have, like switchmen, determined the tracks along which action has been pushed by the dynamic of interest." 150

Rather than emphasizing the exclusive role of "values" as engendering capitalistic growth, Weber is proposing a much more specific role of "ideals." In analytical terms, the statement sees ideals as necessary but not sufficient to effect historical change. The "dynamic of

147 Jackson Toby, Parsons' Theory of Societal Evolution, in TALCOTT PARSONS, THE EVOLUTION OF SOCIETIES, at 1, 20 (1977).

148 Guenther Roth, Global Capitalism and Multi-Ethnicity: Max Weber Then and Now, CAMBRIDGE COMPANION TO WEBER 117, 118 (2000) ( “... Weber disclaimed an 'inner sympathy' with capitalism, as against the champions of older laissez-faire doctrines, he defended, as a 'rather pure bourgeois,' the imperatives of the capitalist market place against its many detractors from the right and left... Not a policy operating with anticapitalist slogans ... but ... the resolute insistence on promoting our bourgeois-industrial ... development is the only economic policy feasible in the long run in the age of capitalism, whether you love it or hate it' [MWG I/4:672f]"

[cite for vulgar Marxism and for Weber's opposition to it, see Allen and Parkin] 149 cite Allen, Parkin

150 (pp.277-278, From Max Weber: Essays in Sociology (1946) (H.H. Gerth \& C. Wright Mills trans.) (note that Mills was a prominent leftist sociologist, see Allen. ) 
interest" pushes social activity along one "ideals" track over another. Without this dynamic of interest, therefore, ideals could not take hold and flourish. At the same time, this statement tells us, ideals ultimately play the shaping role, the mold into which underling interests drive social action.

Thus, Weber's statement that "not ideas, but material and ideal interests, directly govern men's conduct." 151 Weber sought to explain the important role that norms play in shaping behavior, resisting an explanation of social action that looked solely to the structure of the economic "means of production." As will be further explored below, however, Weber's understanding of norms seemed imbued by a distinctly dimmer mood than that of Parsons. Weber explicitly recognized the subordinating role that norms could play in effectuating the domination of members of society to the ruling elite. Indeed, in this conceptual interrelationship between dominant norms and material interests, Weber's theory might be read against the work of subsequent critical theorists in a new light. This will be explored further below, ${ }^{152}$ but for present purposes the main point is that Weber's theory viewed material interests as a centrally important factor, interacting with "ideal interests" and driving social action along the "tracks" laid by those ideal interests to shape history.

By contrast, New Weberian scholars have pointed out that Parsons drained much of the influence of the nonnormative from Weber's theory. Cohen et al argue that "In attempting to assimilate Weber's formulations of his own version of action theory, Parsons asserted that a "focus of interest on the normative aspects of the action systems" was basic to Weber's scheme. ... According to Parsons, ... 'there is

151 (pp.280, From Max Weber: Essays in Sociology (1946) (H.H. Gerth \& C.

Wright Mills trans.) (note that Mills was a prominent leftist sociologist, see Allen. See German original and consider stating it here with an opinion on whether faithfully translated or not.)

152 See infra. 
no such thing as action except as effort to conform with norms' for Parsons (1949: 76-77, emphasis added)."153

Thus, while Parsons argued correctly that Weber had a focus of interest on the normative aspects of action, he exaggerated by asserting that norms are central to Weber's conception of social action. On issues where Weber made no mention of norms or explicitly denied their importance, Parsons claimed (to the contrary) that norms were important to Weber. When Weber stated that norms were of varying importance, Parsons asserted their central importance. When nominated other factors as being primary, Parsons elevated norms to a position of centrality and deemphasized nonnormative factors. The consequence is that Weber's conception of action theory was distorted. ${ }^{154}$

The New Weberians suggest, by contrast, that in Weber's analysis self-conscious value-orientation is only one type of social action. Moreover, Weber felt that value-rational action was both potentially antagonistic to, and constrained by, the instrumentalities of modern statehood.

How does Weber's analysis of the Protestant ethic in

153 P.233

154 Cohen et al:

"Action may be oriented on instrumentally rational, value-rational, effectual or traditional grounds. That is, the actor's orientation may be determined (Weber, 1968: 24-25) principally by his 'expectations as to the behavior of objects ... and of other human beings,' by his 'conscious belief in [a] value for its own sake,' by his 'specific affects and feeling states,' or by 'ingrained habituation.' Weber (1968: 29) also noted three types of subjective meaning common in social action: usage, custom and complex of interests. That is, an action may be performed repeatedly because of current use, because of long familiarity, or because of stable opportunities for realizing interests.

"Parsons perceived all three of these types of subjective meaning as essentially normative. In addition, he viewed as essentially normative three of the four categories for orienting action: traditionalism, instrumentally rational action and value rational action... However, a category-by-category analysis shows that traditional behavior, usages and customs are primarily habitual, while instrumentally rational behavior and complexes of interests are largely oriented to expediency rather than to norms. Only value-rational behavior is primarily normative in any of the senses intended by Parsons." 
driving capitalism, a striking example of value-rational conduct, mesh with this analysis of the types of social action? The value-rational conduct that gave rise to effective capitalistic conduct would, like all other types of religiously motivated behavior, come to be constrained by the very state and society that arose initially out that behavior. 155 This was one of the paradoxes that Weber underscored: the way in which the very religious values which initiated modern activity - industry in the economic sphere, scientific inquiry, and even the rule of law --- would ultimately create institutions that would destabilize the values that birthed them. This destabilization of values was what Weber called the "disenchantment" of modern society, described above.

Given Weber's attention to disenchantment from value-rational action, Parsons' interpretation of this typology of social action as value-driven is curious. This emphatic focus on ideals seems to be inspired more by the Protestant Ethic than by the source of the typology itself, in Economy and Society.

The rather exclusive attention to ideals also manifested itself in Parsons' analytical distance from material conditions as causes of social action and determinants of social relations. Weber, by contrast, specifically warned that his intention was not "to substitute for a one-sided causal materialistic an equally one-sided spiritualistic causal interpretation of culture and of history."156 Cohen et al argue: "While we cannot be certain whether Parsons misunderstood the target of Weber's critique of 'Marxian historical materialism,' he clearly missed its substantive point. Weber quite clearly retained the

155 see, e.g., John Patrick Diggins, Max Weber: Politics AND the Spirit of TRAGEDY 26 (1996) (describing Weber's theory of capitalism as a "sociological phenomenon springing up originally from religious convictions, which would eventually give way to secularization as the entrepreneur continued to demonstrate his qualifications as a Christian by his business integrity.")]. 156 Weber, Protestant Ethic , at 183. 
interest category (including material interest) as a central motive for action and as an important social force; he rejected only sociological formulations that assigned an exclusive attention to self-interest (especially material interest). In contrast, Parsons very nearly read the interest category out of Weber altogether, thereby denuding his work of its attention to the 'dynamic of interest' as a basic motive for action." 157

The excision of nonnormative interests in Weber served to underscore and possibly to distort Weber's discussion of the role of Protestant "values" in producing capitalistic behavior. Whereas Weber sought to describe Protestantism as one particular historical source of a more general phenomenon, the Parsonian approach tends to cut away and deemphasize this historical and analytical complexity. Combined with Parsons' attraction to universalistic and prescriptive analysis, this approach can end up simplifying Weber's thesis into the proposition that Protestant values not only helped generate capitalistic behavior, but that they are actually "necessary" for capitalism to take root as a general matter. "For Parsons, revolutions in consciousness, not the inexorable unfolding of technological power or the contradictions of class society, provided the critical turning points in history."158

An endorsement of capitalistic and scientific values from a normative perspective was part of Parsons' selfconscious understanding of the intention behind his work. In his introductory description of the objectives of setting out a systematic theory of social action, Parsons made clear that the focus of this theory: "the interpretation of 'capitalism,' 'free enterprise,' 'economic individualism,' as it has been variously called."159 Parsons was partially

157 COHEN P.236 argue

158 Gilman, Nils. Mandarins of the Future., 2004. p 93.

159 (The Structure of Social Action (1949, p.vi). 
motivated by a special plea directly from Friedrich von Hayek, who saw ${ }^{160}$ Weber as an "ideological forerunner" for a theory of economic growth that eschewed "public regulation" suggested by Marxian and Keynesian policies. ${ }^{161}$

Just as the argument for deregulatory politics served as an important and explicit counterpoint to advocates for socialist statist policy, the argument for the importance of beliefs served as an important and explicit counterpoint to proponents of the view that the primary deficit in the developing world was the absence of capital. The latter formed an important part of dependency theory, which argued that colonizing countries had extracted capital from colonies in addition to establishing market patterns that created economic dependency of the peripheral colonies on the metropolitan center. ${ }^{162}$

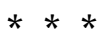

Weber was a self-described bourgeois ${ }^{163}$ who strongly supported the German state ${ }^{164}$ and one who may have believed that the developing world was 'inherently' disqualified to generate development. ${ }^{165}$ Yet he became one of the intellectual forefathers of the modernization movement. This article suggests that, unfortunately, when it comes to the application of Weber's theories to development,

160 [in Weber's Protestant Ethic, but I don't know if Hayek was relying only on that, have to look more at Hayek and also at this letter] 161 (Kieran Allen, Max Weber, at 7 (citing T. Parsons, "The

Circumstances of My Encounter with Max Weber," in R. Merton and M.W. Riley eds., Sociological Traditions from Generation to Generation: Glimpses of the American Experience, 1980, at pp.38, 42).

162 See Andre Gunder Frank, the Development of Underdevelopment. For an explicit denunciation of Parsonian methodology see Andre Gunder Frank,The Sociology of Development and the Underdevelopment of Sociology (London: Pluto Press 1971).

163 (quote)

164 (quote)

165 (quote). 
much in development policy has inherited too much from the Eurocentric sensibility of Weber's work and not enough from the sophistication of his analyses. The sophistication of this theory was not trivial. Streamlined in the service of a particularly American version of free market capitalism, Weber's analysis was stripped of insights that in fact might have predicted many of the lessons that were learned the hard way from the application of the "evolutionary universals" model that developed. The desire to create a viable and clearly opposed alternative to socialism in the Cold War era likely inspired Parsons and others simply to elide and underplay the role that material interests, and Marxian analysis, had in shaping Weber's own theory. Again, the solution threw the baby out with the bathwater: in gravitating towards an idealist explanation for capitalist development, the Parsonians set themselves up for policies that were not only misguided but ineffective.

\section{A.3. Parsons and Theoretical Shortcut \#3: The Correlation Between Modernization and Democracy}

Parsons argued that the "necessary breakthroughs" for modernization were of a piece and included the contemporaneous rise of capitalism and democracy: "the institutionalization of the authority of office, the use of market mechanisms for mobilizing resources, a generalized legal order, and the democratic association."166 Parsons did not devote much attention to exactly how democracy would arise or how it would operate. ${ }^{167}$ Rather, Parsons assumed a naturalistic relationship between modernization and democracy - as the former emerged, the latter would

\footnotetext{
166 Jackson Toby, Parsons' Theory of Societal Evolution, in Talcott Parsons, The Evolution of Societies, at 1, 13 (1977). 167 [cite]
} 
naturally take root. In his 1964 essay, Evolutionary Universals in Society, Parsons explicitly applied evolutionary theory to identify centralized political legitimacy, the emergence of political rationalization through bureaucracy, and "the democratic association with elective leadership and fully enfranchised membership" as naturally co-evolving hallmarks of modernity. ${ }^{168}$

The casual assertion of the link between modern bureaucracy, capitalism and democracy may have stemmed from the fact that Parsons did not analyze the role of power in his list of functional imperatives.169 Rather, Parsons expressed a highly idealized version of the actual functioning and social role of "the institutions of political democracy" such as electoral franchise. ${ }^{170}$ This was consistent with this neoclassical orientation in terms of political and economic theory, and with his objective of counteracting oppositional theories then competing for allegiance in the realm of international economic policy. ${ }^{171}$ Thus, "pessimism was the aspect of Weber's thought that ... Parsons had labored so hard to downplay in Toward a Theory of Social Action."172

Although Parsons recognized coercion as a factor in Weber's analysis, ${ }^{173}$ he nevertheless underplayed that aspect

168 Talcott Parsons, Evolutionary Universals in Society (1964).

169 "Had he regarded power in this way, Parsons might have seen that effective social goals are of necessity those that are desirable from the standpoint of the powerful. This might have led him to [investigate the] hierarchical definition and enforcement of social goals...." [p.151] Chandler Morse, The Functional Imperatives, p.100 in The Social Theories of Talcott Parsons: A Critical Examination (1961).

170 [pp.298-301] Andrew Hacker, Sociology and Ideology, p.289 in The Social Theories of Talcott Parsons: A Critical Examination (1961).

171 Parsons' "conservative' bias" had been oft remarked on - actually it is more of a classical liberalism: "it is the ideology of John Locke and John Stuart Mill, the ideology of political liberty and a free society." [pp.290-291] Andrew Hacker, Sociology and Ideology, p.289 in The Social Theories of Talcott Parsons: A Critical Examination (1961).

172 Nils GILMAN, MANDARINS OF THE FUtURE 55 (2004).

173 (Parsons The Structure of Social Action 1949, pp. 658,717; Talcott Parsons, Max Weber and the contemporary political crisis, Review of Politics vol 4 (1942), 
of Weber's analysis in multiple ways. The first was through his own selective culling of Weber's theoretical concepts. As Cohen et al observed, Parsonian theory holds that "common values are the sine qua non of the social order."174 Parson's reading of Weber not only emphasized normative interests driving individual activity at the expense of internally identified non-normative factors such as material interest, as discussed above, but also emphasized those normative interests at the expense of externally determined nonnormative factors, such as coercion: "Parsons' great stress on the alleged importance of the 'common value' in Weber's work forced a fundamental reordering of Weberian perspectives on the significance of ideas and interests in social action, and eventually resulted in misinterpretation of Weber's perspective on domination."175

The Structure of Social Action accomplishes this reordering partially through omission. Most of Parson's treatment of Weber focuses on his sociology of religion, lending force to the collective-value, normative analysis. Only a small portion of Structure of Social Action focuses on Weber's treatment of power.

Yet power ultimately played a central role in Weber's analysis of modern governance. As noted above, Weber's theory was inflected by a Nietzschean sensitivity to "structures of dominancy."176 New Weberians Kieran Allen and Cohen et al have argued that a "correct understanding of Weber's general sociology is impossible unless founded on a faithful reading of this theory of" power. ${ }^{177}$

This bowdlerizing tendency in Parson's reception of

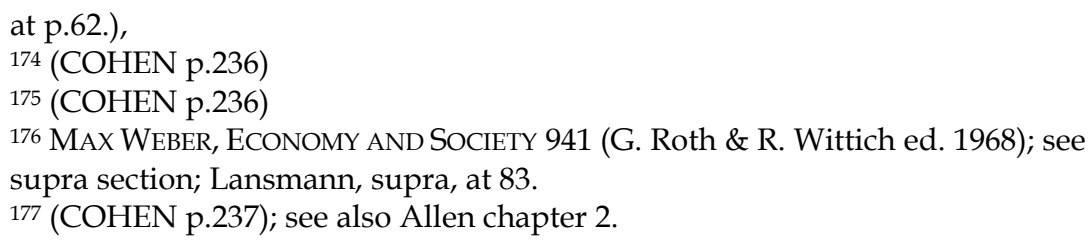


Weberian was perhaps most famously displayed in his translation of Weber's ideal types of governance, or Herrschaft. The term forms the basis for Weber's classic and perhaps best known analysis, his formulation of the ideal types in social structures as deriving from forms of power or Herrschaft that are "traditional," "charismatic" or "formalrational" in nature.

The plain, unvarnished definitions of Herrschaft in contemporary German-English dictionaries - as "rule" or "dominion" - seem to capture the term's blending of coercion by the elite together with some basic level of acceptance, if not full consent, by the masses. ${ }^{178}$ English translations of Weber's Economy and Society, however, have tended to err on the side of either coercion or consent, construing Herrschaft as "authority," highlighting consent, or "domination," highlighting coercion.

Guenther Roth, in his translation of Economy and Society, chose to translate Herrschaft as "domination." Roth's choice of "domination" mirrored that of Reinhard Bendix, who in his book of Max Weber explicitly discussed the difficulty of translating Herrschaft, preferred the term "legitimate domination."179 Parsons, however, preferred the

178 Herrschaft: "power, rule, reign" - p.381 - 2002 Cambridge Klett Comprehensive German Dictionary; "rule, dominion (uber); mastery, power, control" p.927 Langenscheidts Taschenworterbuch Englisch (1956).

179 In his section on Legal Domination, Bendix begins with a footnote describing the difficulties of translating Weber's term Herrschaft:

It is difficult to find an English equivalent for the German term Herrschaft, which emphasizes equally the ruler's exercise of power and the follower's acceptance of that exercise as legitimate, a meaning which goes back to the relations between lord and vassal under feudalism. The English terms "domination" and "authority" are not equally apt, because the first emphasizes the power of command whether or not consent is present, while the second emphasizes the right of command and hence implies the follower's acceptance almost to the exclusion of the ruler's very real power. Weber wished to emphasize that both power and consent are problematic, but 
term "leadership." Parsons' rendition of Herrschaft, therefore, plays up the "consent" side of the term even more than "authority."

In a review of Bendix's "intellectual portrait" of Weber, Parsons explained: "The term [Herrschaft], which in its most general meaning I should now translate as "leadership," implies that a leader has power over his followers. But "domination" suggests that this fact, rather than the integration of the collectivity, in the interest of effective functioning ... is the critical factor from Weber's point of view ... The former interpretation [does not represent] the main trend of Weber's thought, though he was in certain respects a 'realist' in the analysis of power. The preferable interpretation ... is represented especially by his tremendous emphasis on the importance of legitimation ... legitime Herrschaft [was] for Weber ... overwhelmingly the most significant case...."180

The New Weberians have explored at length the difficulties of translating Weber's Herrschaft into English. In particular, Cohen et al. devoted extensive discussion to the Parsons' misuse of the term. Cohen et al. dispute that Weber's "prime emphasis was on either (1) leadership in the interest of effective collectivity functioning or (2)

as a realist in the analysis of power he would have been critical of any translation that tended to obscure the 'threat of force' present in all relations between superiors and subordinates. For these reasons, I prefer the term 'domination.'

p.481. Bendix puts his finger on a difficulty of translation in Weber's concept subtly blending - and conceptually requiring - both the notion of coercion and the notion of consent. When unpacked in this way, the seemingly intended meaning of the term Herrschaft remarkably comes within striking distance of Antonio Gramsci's concept of hegemony. Indeed, some Frankfurt School would employ Weberian concepts their critique of modern society.

180 Talcott Parsons, Review of Reinhard Bendix, Max Weber: An Intellectual Portrait, 25 AMERICAN SOCIOLOGICAL REVIEW 750 (1960). 
legitimation."181 Rather, Cohen et al. argue that "Weber did not suggest that dominant persons act to integrate collectivities in the interest of effective functioning. Rather, he treated such individuals as acting in terms of their own ideal and material interests as they perceive them."182 Moreover, Cohen et al. found Parson's emphasis on legitimating as "no more convincing than Parson's related attempt [concerning] leadership."183 Cohen et al. point to Weber's statement that "although Herrschaft does not 'in every case ... utilize economic power for its foundation and maintenance, ${ }_{, \prime,}$ in the vast majority of cases, and indeed in the most important ones, this is just what happens... and often to such an extent that the mode of applying economic means for the purpose of maintaining Herrschaft, in turn, exercises a determining influence on the structure of domination."

Moreover, Cohen et al. argue that, whereas Parsons emphasized the importance of "belief in legitimacy" in explaining the basis of power in social structures, Weber allowed that Herrschaft could be based in "physical coercion; habituation to which at least under certain conditions Weber applied the label 'discipline'; rational calculation of interests, a specific version of which is founded in relationships of expertise; and belief in the legitimacy of perceived order."184 Thus, Weber wrote:

"It is by no means true that every case of submissiveness to persons in positions of power is primarily for (or even at all) oriented to this belief [in legitimacy]. Loyalty may be hypocritically simulated by individuals or by whole groups on purely opportunistic grounds, or carried out in practice for reasons of material interest. Or people may submit from

181 (COHEN p.237)

182 COHEN p.238.

183 COHEN p.238.

184 MAX WeBER, ECONOMY AND SOCIETY 53-4, 212-214, $942-946$ (G. Roth \& R. Wittich ed. 1968). 
individual weakness and helplessness because there is no acceptable alternative." 185

Cohen et al. conclude: "In short, contrary to Parsons, who attempted to equate Herrschaft with legitimate domination, Weber considered nonlegitimate domination at least equal in importance to legitimate domination.... Although Weber's multiple-factor approach is a dominant motif in his discussions of Herrschaft, a second emphasis is ... on power and not, as Parsons would have it, on leadership ... or legitimacy."186

As subsequent New Weberians have pointed out, these difficulties in translation probably have had at least as much to do with the Anglo-American tradition of political thought as with linguistics. While Cohen et al. critique the lack of attention to "nonlegitimate" rule in Weber's thought, at least as problematic was the understanding of the term "legitimate" itself. Weber's understanding of the term appears to have been strictly positivist, referring to the actual willingness of subjects to obey authority rather than to any normatively valid basis for their obedience. "Weber's uncanny ability to equate authority with power flew in the face of the more optimistic outlook of western political philosophy which assumed that the Enlightenment's legacy had resolved the problem by defining all legitimate authority as deriving from voluntary consent." 187

Lansmann elaborates on the Weber's understanding of legitimation, arguing that it was "not concerned with the normative question of whether or not that body of rules ought to be considered legitimate." 188 This approach was

185 MAX WeBER, ECONOMY AND SOCIETY 214 (G. Roth \& R. Wittich ed. 1968). 186 (COHEN at p.239)

187 John PATRICK Diggins, Max Weber: Politics AND the SPirit OF TRAgedy 62 (1996).

${ }^{188}$ Lansmann, supra, at 87: “This is a point where many of Weber's critics argue that he has unjustifiably altered the generally accepted meaning of the concept. Weber ignores the argument that a concept such as 'legitimate' has implicit normative implications and cannot, therefore, be used in a 'neutral' manner. 
shaped by Weber's methodological affinity both with "legal positivism and post-Nietzschean skepticism."189 Eliason further explores the difference between Anglo-American political thought and Weber's post-Nietzschean, antiHegelian approach:

"For an Anglo-American... [1]iberalism means 'freedoms,' enshrined politically as rights and protected by various institutional methods which limit state authority... The core problem of liberalism is state power: limiting it, controlling, or alternatively of justifying its political role which is to be determined by constitutions and by democracy or more broadly by consent arising through discussion. Weber, however, was far removed from all of this. He had no sentimental attachment to either democracy or parliamentary forms. 'Rights' barely exist as a concept in his texts, and when they appear they do so as a valuable residue of past fanaticism. ... Indeed, he showed little affinity even with German liberalism, which made its own distinctive contribution to the liberal tradition with the idea of Rechstaat, the ideal of a state of laws not of men... Weber hardly used the word Rechstaat. The explanation for this is that the word itself has natural-law connotations. And natural law was alien to Weber, who was very pronounced in favor of what we might call legal positivism - or, maybe better, legal realism, since there were lingering elements of natural law in the legal positivism of his day..."190

According to Weber's critics to describe a regime as legitimate must be to refer to a valued achievement other than the contingent fact that its citizens appear to obey its laws or just happen to believe it to be legitimate."

189 Landesman continues: “Weber was, in many ways, influenced by both legal positivism and post-Nietzschean skepticism. He was not concerned with the problem of which regimes are normatively legitimate, but with a different question: ... 'how can modern regimes legitimate themselves or be held to be legitimate?'” P.88.

190 Eliaeson, supra, at 136-137. 


\section{A.4. Parsons and U.S. Foreign Policy}

The "confluence of U. S. foreign policy needs and the ambitions of Parsons and his collaborators would provide the foundation for a social scientific theory of social change,...

Parsonian theory would provide a basis for uniting the particularistic studies being made in Area Studies programs into a single, coordinated research and policy agenda." ${ }^{191}$ In formulating that agenda, Parsons was particularly motivated by the desire to provide an "American alternative to Marxism," as his theory would subsequently come to be called. ${ }^{192}$ In this Cold War context, Parsons sought to portray Weber - and his theories about capitalism as interpreted by Parsons - as "above political conflicts." 193

Parsons explicitly situated his analytical framework of evolutionary universals in the policy divide between capitalism and socialism. The notion that the major engine of growth and development lay in the "beliefs" of members of society found important support in Max Weber's exposition of the role of Protestant ideals in spurring capitalist development in Western Europe.

Parsons was motivated to establish the universality of his theory at least in part out of the same concerns that animated his endorsement of normative factors, namely a desire to exclude and delegitimate rival Marxian accounts of economic growth. In fact, Parsons declared "special reasons" for downplaying the role of nonnormative interests, and underplaying the problematic conceptual role of democracy, in his reading of Weber. ${ }^{194}$ These reasons

191 Gilman, Nils. Mandarins of the Future. 2004. p 73.

192 (P.177, Gouldner, The Coming Crisis in Western Sociology, cited in Kieran Allen, Max Weber at 7.)

193 "Weber thus entered the canon of American sociology as a 'value free' sociologist." (Allen, Max Weber, at p.8. Discuss the value free issue a bit more here - see Allen at p.73, Parkin.) 194 See T. Parsons, “On ‘De-Parsonizing Weber,' American Sociological Review October 1975 at p.668. 
related to his desire to deprivilege and delegitimate rival accounts. ${ }^{195}$ In particular, excising Weber's sociocultural "pessimism" from his own theory allowed Parsons to "craft a Weberian theory that permitted [the] image of American modernity as a wonderful thing." 196

Parsons sought not only to emphasize the importance of capitalist beliefs, but also to situate this causal variable in a universalist analysis of economic growth and social change. Central tenets of modernization theory were that (1) there is a universal path towards economic development which features the emergence of a highly differentiated social structure; (2) this path features the centrality of free market entrepreneurs; (3) states that wish to succeed in economic development should do as much as possible to free constraints on entrepreneurs and investors. ${ }^{197}$

The dependentista development theorist Andre Gunder Frank observed that, although Parsons himself was not primarily focused on the developing world, "[a]rguably "development" was the field in which Parsonianism became the most influential, even though it was rather far removed from his own immediate concerns. It was Parsons who translated Weber into American ..., and it was post-War but Cold War America that used Parsonized Weber to conquer the post-colonial Third World in apparent competition with the Soviet Union and China." 198

According to Kieran Allen, Parsons worked with the

195 See T. Parsons, “On 'De-Parsonizing Weber,' American Sociological Review October 1975 at p.666, seeking to "clarify ... the relation between economic theory and sociological theory."

196 NiLs GILMAN, MANDARINS OF THE FUTURE 55 (2004).

197 This was the view, for example, represented by Hayek's reading of Weber.

198 Andre Gunder Frank post. Frank was a central proponent of dependency

theory, and also was perfectly aware of the interconnections between Parsons, as an interlocutor of Weber, and modernization theorists such as W.W. Rostow.

[Frank argues that Clifford Geertz, Robert Bellah, Marion Levy, Florence

Kluckhon, Homans et al made direct inputs into development theory and policy. Investigate this.] 
CIA-sponsored "Congress for Cultural Freedom." Allen describes the Congress of Cultural Freedom as an "organization that sought to wage an intellectual struggle for the hearts and minds of left leaning intellectuals."199 While

199 (Allen at p.8 [Other scholars involved with the Congress for Cultural Freedom, such as Daniel Bell and Seymour Lipset, interpreted Weber as supporting a reading of market-oriented democracy as constituting the endpoint, for both pragmatic and ontological reasons, of human evolution. Daniel Bell wrote The End of Ideology (1960), which viewed Weber as an important intellectual predecessor of the pragmatic argument (see D. Bell, The End of Ideology: On the Exhaustion of Political Ideas in the Fifties, 1960, at p.279). Seymour Lipset also relied on Weber's theories for the ontological argument that liberal democracy decisively represented the "good society itself in operation." See Lipset, 'The End of Ideology' in C. Waxman ed., The End of Ideology Debate (1969 at p.69). Together, Edward Shils, Daniel Bell and Seymour Lipset, all finding intellectual support in Weber, formed the American center of the Congress for Cultural Freedom. See Scott-Smith at p.443] [Gilles Scott-Smith provides a detailed history of the rise and plateau of the Congress for Cultural Freedom. See Giles Scott-Smith, "The Congress for Cultural Freedom, the End of Ideology and the 1955 Milan Conference: 'Defining the Parameters of Discourse' in Journal of Contemporary History, Vol. 37, No. 3, 437-455 (2002). Rather than ideological neoliberals, both Bell and Lipset supported an approach that would view itself as "non-ideological" and as essentially espousing some version of an "Atlantic consensus" finding common ground between European social democracy and American New Deal-ism. See Scott Smith at p.442. In the early phase of the CCF, this brand of moderate welfare statist politics served as an alternative to the threat of "hard-line" Marxism and totalitarianism. After the death of Stalin in 1953, and the perceived decline of the hard-line Marxist/totalitarian alternative, the members of the CCF began to view the differences between various brands of industrial democracy as essentially minor, and the "end of ideology" discourse was born. See Scott-Smith at pp.438,440. Henceforth, the challenge for the modern Western state was a scientistic one related to managing productivity and engineering specific solutions to social problems within a broadly Fordist context. See Scott-Smith at p.441. The CCF soon faced challenges both from those espousing a more deregulatory approach Hayek was a vocal "dissenter" within the CCF's "Atlantic consensus" (See ScottSmith at p.451). It also began to face challenges from the global South, beginning with India but soon burgeoning into the state organizers of the Non-Aligned Movement. See Scott-Smith at pp.454, 455. The voices from these quarters seemed to be calling for a revival of socialist and authoritarian politics, a challenge that Scott-Smith describes as ultimately too foreign and too large for the short-lived statist "Atlantic consensus" of the CCF. See Scott-Smith at p.455 (" the gap between West and South was much greater than that between the USA and Western Europe, and the CCF would have difficulties in exporting its ideas beyond the 'Atlantic consensus' of the Euro-American intelligentsia").] 
the CCF endorsed a moderate Fordism, 200 the interpretation of Weber in Parsons emphasized Weber's espousal of freemarket capitalism in the Protestant Ethic, combining that with Weber's notion of ideal types to create a potent theory of modernization.

Based at Harvard's Department of Social Relations (DSR), Parsons was able to work with contemporaries to shape an agenda for social science that could be immediately transferred to U.S. foreign policy initiatives. ${ }^{201}$ The DSR, underwritten by the Carnegie Corporation, sponsored scholarly exchanges with Edward Shils and others at the University of Chicago for the purpose of establishing a single, general account of modernity in the social sciences. ${ }^{202}$

200 The Congress for Cultural Freedom itself stopped short of free market economics, its function ultimately being instead to build support for a more moderate form of market-oriented government, compatible with American New Deal politics and European social democracy, that could serve as a viable alternative to leftists. The CCF's theoretical center seemed to rely on a reading of Weber that saw, in Weber's discussions of bureacracy, support for a Fordist state. 201 NiLs GILMAN, MANDARINS OF THE FUTURE 73 (2004). Gilman's description of the influence of Parsons in the emergence of this scholarly agenda is worth quoting at length:

...U. S. foreign policy needs and the ambitions of Parsons and his collaborators would provide the foundation for a social scientific theory of social change, which would eventually come to be known by the name modernization theory. [Parsons' Department of Social Relations or DSR] would shape modernization theory.... First, Parsons articulated more fully than any other contemporary American scholar ... the concept of modernity that would provide a fundamental, if usually implicit, template for both intellectuals and policy makers in their understanding of the desirable direction and ultimate goal of change in the postcolonial world. Second, [DSR] members helped redirect postwar social theory away from social critique and toward the creation of a descriptive ... theory of human action.... This social theory would help justify the creation of technologies of social reform, mostly applied to non-Western countries. Third, the DSR was the institutional fountainhead for the promotion of Parsonian social theory, which provided the foundation for modernization theory. ... [T] he DSR provided an institutional presence for the employment and training of students of modernization. Most of the sociologists associated with modernization theory had some affiliation with the DSR as either professors or collaborators. 202 Id. 
This account contained all of the qualities described above. The definition of modernity as occurring through evolution along a single, universal path, characterized and spurred primarily by social "values," and leading to a highly "differentiated" social structure in which bureaucratic governance, modern capitalism, and democracy all naturally co-existed. Parsons viewed the United States as occupying the apex of this evolutionary trajectory. "Moreover, since historical change had to come from outside the system, Americans were obligated to go out and help other societies get moving toward greater differentiation."203 Parsons' prescriptions for "help" were "welcomed with especial warmth in development studies." ${ }^{204}$ The application of Parsonian analysis to the objective of economic development would produce one of the leading policy frameworks of the mid-to-late twentieth century, Modernization Theory. ${ }^{205}$

\section{B. W.W. Rostow: Modernization Theory Meets Economic Development Policy}

The most well-known of modernization theorists, W.W. Rostow, eagerly absorbed Parsons' scholarship and had "align[ed his] pronouncements with the vision of modernity that Parsons painted." 206 Moreover, Rostow shared and extended Parsons' enthusiasm for concretizing U.S. social science in the form of U.S. foreign policy. ${ }^{207}$ Because of

203 Gilman, Nils. Mandarins of the Future., 2004. p 88

204 Gilman, Nils. Mandarins of the Future., 2004. p 79.

205 Gilman, Nils. Mandarins of the Future. 2004. p 73.

206 NiLs GILMAN, MANDARINS OF THE FUTURE 73 (2004).

207 "The infectious sense of excitement, of being on the verge of unlocking the mysteries of human sociability, appears throughout the writings of modernization

theorists (and indeed most social scientists of this period). 'A very big scientific development has been rapidly gathering force,' Parsons explained to Dean Buck. 'I will stake my whole professional reputation on the statement that it is one of the really great movements of modern scientific thought.' 
Rostow's enormous influence in economic development theory and U.S. foreign policy, this methodological alignment proved among the most significant channels for the transmission of Parsons' understanding of Weberian theory - and of Parsons' Theoretical Shortcuts.

\section{B.1. Rostow and Theoretical Shortcut \#1 ("One-Size-Fits- All"): From "Evolutionary Universals" to "Stages of Growth"}

Parsons and Rostow shared a methodological ambition to conceptualize "modernization" as "a comprehensive and cohesive process that entailed what Max Weber had called 'rationalization.'" 208 As such, both theorists ignored Weber's own cautions regarding an evolutionary understanding of his "ideal types." 209 Both theorists helped to divert Weberian historical analysis into a "one-size-fits-all" prescriptive approach.

Walt Whitman Rostow was among the most influential transmitter of this approach in economic development policy. ${ }^{210}$ In the Process of Development (1952)

Walt Whitman Rostow agreed that synthetic social science was nothing less than revolutionary: 'The revolution may be defined as an effort to achieve a more unified application of the social sciences. ...,' a project that he believed would "get much assistance from the current generation of political scientists who are increasingly committed to the study of comparative politics in non-Western societies." Gilman, Nils. Mandarins of the Future. 2004. p 78.

208 NiLs GILMAN, MANDARINS OF THE FUTURE 5 (2004).

209 See Wolfgang Schlucter, Psychophysics and Culture, in CAMBRIDGE COMPANION TO WEBER 59, 70 (2000) (arguing that Weber "fundamentally rejected organic analogies in economics and sociology" and by extension social Darwinism). 210 Michael Adamson, Social Scientists as Policymakers, 14 HumANE STUdiEs Review (2000); David Steigerwald, The Paradoxes of Kennedy Liberalism, 28 REVIEWS IN AMERICAN HISTORY 636 (2000). (See Gunder Frank post, arguing that Parsons was "arguably with What Whitman Rostow one of the ... defining theoretical/ideological leaders with the widest influence on cold war rhetoric and policy...."). 
and The Stages of Growth: A Non-Communist Manifesto (1962), ${ }^{211}$ Rostow carried elements of Parsons' analysis to the more streamlined world of development policy and practice. 212

The Stages of Economic Growth, in particular, stylized the analytical components of Parsons' work, causing a deepening of Parsons' key elisions of Weber. Rostow dramatically simplified Parsons' analysis of "evolutionary universals." Parsons had maintained a belief in the validity of the concept, but in his exposition generally sought to maintain complexity. 213 Rostow, on the other hand, reduced social change throughout all of human history to five stages of economic growth: 214

1. the "traditional society" stage ("whose structure is developed within limited production functions, based on pre-Newtonian science and technology, and on pre-Newtonian attitudes towards the physical world")215;

2. the "preconditions for takeoff" stage (the period in which society transitions from a traditional formation to one ready to "exploit the fruits of modern science,

211 Other works by Rostow include: The American Diplomatic Revolution; Essays on the British Economy of the Nineteenth Century; The Process of Economic Growth; The Growth and Fluctuation of the British Economy, 1790-1850; The Dynamics of Soviet Society; The Prospects for Communist China; An American Policy in Asia; A Proposal: Key to an Effective Foreign Policy; The United States in the World Arena; Politics and the Stages of Growth; and The Diffusion of Power.

212 Michael Latham argues that Parsons and Edward Shils had developed the central tenets of modernization theory by the 1950s. MichAEL E. LATHAM, MODERNIZATION As IDEOLOGY: AMERICAN SOCIAL SCIENCE AND 'NATION-BUILDING' IN THE KENNEDY ERA (2000).

213 [CHECK]

214 Rostow, The Stages of Economic Growth (3 ${ }^{\text {rd }}$ ed., 1960), at 4 ("It is possible to identify all societies, in their economic dimensions, as lying within one of five categories.").

${ }^{215}$ Rostow, The Stages of Economic Growth (3rd ed., 1960), at 4. 
fend off diminishing returns, and thus to enjoy the blessings and choices opened up by the march of compound interest");

3. "the take off" stage (the "interval when the old blocks and resistances to steady growth are finally overcome");

4. the "drive to maturity" stage ("a long interval of sustained if fluctuating progress, as the now regularly growing economy drives to extend modern technology over the whole front of its economic activity");218 and

5. the "age of high mass consumption" ("where, in time, the leading sector shift towards durable consumers' goods and services"). ${ }^{219}$

Weber's ideal types had morphed into Parsons' evolutionary universals and now into Rostow's "five stages." 220

Indeed, Rostow's confidence in the universality of this sequence was such that he felt confident even in estimating a universal time-frame for movement across the stages once the "take-off" triggered the process of sequential change: "Historically, it would appear that something like sixty years was required to move a society from the beginning of take-

216 Rostow, The Stages of Economic Growth (3rd ed., 1960), at 6.

217 Rostow, The Stages of Economic Growth (3rd ed., 1960), at 7.

218 Rostow, The Stages of Economic Growth (3rd ed., 1960), at 9.

219 Rostow, The Stages of Economic Growth (3rd ed., 1960), at 10.

220 Rostow's contemporary Alexander Gerschenkron adopted a more sophisticated theory of modernization, which ultimately eclipsed Rostow's in terms of respectability in the academy. Gerschenkron also advocated a "linear stages" version of economic development and famously developed "historical backwardness" as a descriptive ideal type. See Alexander Gerschenkron, Economic Backwardness in Historical Perspective, 1962. He also believed that countries could sometimes skip stages through the adoption of advanced technology and through managed state intervention. 
off to maturity." 221

The only qualification Rostow felt it necessary to add to this general theory arose in the cause of a society's initial propulsion into this sequence. Although the "preconditions for take-off were initially developed, in a clearly marked way, in Western Europe... [t]he more general case in modern history... saw the stage of preconditions arise not endogenously but from some external intrusion by more advanced societies." 222

In his "Stages of Growth" theory, Rostow adopted the theoretical inclination of Parsons towards a universal structuralism. In pursuing this inclination, Parsons and Rostow shared more, methodologically, with Marxian rather than Weberian theory. For Rostow in particular, the construction of a methodologically similar alternative to Marxian structuralism appears to have been fully intentional. As the subtitle of Stages of Economic Growth indicates - a "Non-Communist Manifesto" - an explicit goal of this account was to counter the historical materialist focus on economic dynamics of class conflict. ${ }^{223}$

This simplistic universalism was not shared by all modernization theorists. Rostow's contemporary Alexander Gerschenkron, for example, produced a theory of historical transition to modernization that, although sharing its general orientation with Rostow, nevertheless introduced important complications in the form of acknowledging the contingent nature of the preconditions stage, and as well as the role of differences in initial material conditions in

221 Rostow, The Stages of Economic Growth (3rd ed., 1960), at 10.

222 Rostow, The Stages of Economic Growth (3rd ed., 1960), at 6.

223 Charles Kimber Pearce, Rostow, Kennedy, and the Rhetoric of Foreign Aid (2001); Michael Adamson, Social Scientists as Policymakers, Humane Studies Review Vol. 14, No. 3 ("During the 1940s and 1950s, Rostow developed his "stages" theory as a general model of social development to counter Karl Marx's framework for relating socioeconomic factors to social revolution. He presented his theory in public policy forums as practical knowledge for using foreign aid to conduct economic warfare.") 
influencing and differentiating trajectories of modernization among "latecomers." 224 Gerschenkron's personally intimate acquaintance with the "historically backward" society of his native Odessa probably helped to enhance his taste for methodological complexity. While Gerschenkron's theories eventually have come to prevail favor over Rostow's much more simplied version, in the immediate context of midcentury U.S. foreign policy it was Rostow's approach that prevailed. ${ }^{225}$

\section{B.2. Rostow and Theoretical Shortcut \#2: Modernity and "Values"}

Rostow also deepened the Parsonian emphasis on normative factors, and in particular of capitalistic values, as a causal explanation for societal "evolution." Indeed, the primary determinant of societal "takeoff" was the emergence of a capitalist class both willing and able to take risks and make investments of the kind necessary to jumpstart the process of rapid economic growth thought to be characteristic of the modernization process.

While this component of Rostovian theory is often read for the proposition that capital formation is central to economic development, notable in Rostow's own formulation is the emphasis on values. The "external intrusion of advanced societies" is important primarily because it "set[s] in motion ideas and sentiments which initiated the process by which a modern alternative to the traditional society was constructed."226 It is this shift in values which allows the capitalist class to emerge: "The idea

224 Alexander Gerschenkron, Economic Backwardness in Historical Perspective: A Book of Essays. Cambridge, MA: Belknap Press of Harvard University Press, 1962 225 Charles Kimber Pearce, Rostow, Kennedy, and the Rhetoric of Foreign Aid (2001);

226 Rostow, Stages of Economic Growth, at 6. 
spreads ... that economic progress is possible.... New types of enterprising men come forward... willing to mobilize savings and to take risks in pursuit of profit or modernization." 227

Rostow's treatment here recalls, of course, Weber's account of the Protestant Ethic. Weber's account, however, explicitly identified itself as a corrective to, rather than a replacement for, a "one-sided materialistic" view of historical change.228 Rostow, by contrast, appears to view the ideas of progress and profit as uniquely independent variables. Changes in "values," rather than codeterminative of historical change, appear to become their sole cause.

\section{B.3. Rostow and Theoretical Shortcut \#3: Modernity and Democracy}

Like Parsons, Rostow also glossed over the relationship of democracy to economic growth and the market. Rostow asserted an easy, natural relationship between the emergence of economic growth and political democracy. ${ }^{229}$ The emphasis on democracy meshed with the goal of providing an attractive alternative to revolutionary socialism: "As Arthur Schlesinger Jr. put it, modernization theory "represented a very American effort to persuade the developing countries to base their revolutions on Locke rather than on Marx." 230

Rostow shared with modernization theorists generally the "belief that modernization would bring American-style health, wealth, and democracy to traditional nations." 231 Even in the early 1960s, for example, Rostovian

\footnotetext{
227 Rostown, Stages of Economic Growth, at 6-7.

228 See supra cite.

229 See, e.g., W.W. Rostow, View from the Seventh Floor, (1964), at 25.

230 NiLS GILMAN, MANDARINS OF THE FUTURE 10 (2004).

231 NiLs Gilman, MANDARINS OF THE FutUre 9 (2004).
} 
fellow traveler Lucian Pye criticized modernization theory for its "'unreasoned expectation' that democracy was 'inevitable'" once economic take-off had begun. ${ }^{232}$

Although both Parsons and Rostow oversimplified the relationship between modernity and democracy by assuming that the former would promote the latter automatically, the Rostovian version of this oversimplification parted ways importantly from that of Parsons. Parsons assumed away the problem of democracy by neglecting to elaborate on the particular dynamics of its emergence; Rostow assumed away the problem by embracing the necessity of authoritarian rule as an important part of "setting the stage" for democracy. ${ }^{233}$ Rostow and other "high modernists," in James Scott's terminology, endorsed the use of state force to create "administrative order" while the institutional elements required to support bureaucratization and economic growth were put into place. ${ }^{234}$ The "trade-off" between development and democracy seemed acceptable particularly "[i]n the context of an American cold war mentality that considered 'developmental dictatorships' preferable to 'vulnerable' democracies." 235

\section{B.4. Rostovian Modernization Theory and U.S. Foreign Policy}

232 Mark T. Berger, Decolonisation, Modernisation and Nation-Building: Political Development Theory and the Appeal of Communism in Southeast Asia, 19451975, 34 Journal of Southeast Asian Studies 421, 434 (2003) (quoting Lucian W. Pye, Politics, personality and nation-building: Burma's search for identity (1962), pp. xvxvi, 7, 38, 42.); see also Tae-Gyun Park, W. W. Rostow and Economic Discourse in South Korea in the 1960s, 8 JOURNAL OF INTERNATIONAL AND AREA STUDIES 55 (2001), at 59.

233 see also Tae-Gyun Park, W. W. Rostow and Economic Discourse in South Korea in the 1960s, 8 JOURNAL OF INTERNATIONAL AND AREA STUDIES 55 (2001), at 59.

234 James C. Scott, Seeing Like a State: How Certain Schemes to Improve the Human Condition Have Failed (New Haven, Conn.: Yale University Press, 1998). 235 NiLs GILMAN, MANDARINS OF THE FUTURE 11 (2004). 
Rostow's streamlined analytical framework came to characterize "modernization theory" generally: an account of economic growth and social change that focused on the importance of the expanding capitalist nucleus and the shift in beliefs. Rostow's career shows both how this strain of neo-Weberian theory and scholarship on economic growth and social change impacted U.S. policy in developing countries. 236 Rostow adopted a variety of rhetorical approaches in urging U.S. policymakers to adopt and implement modernization theory. Rostow's efforts under Presidents Eisenhower, Kennedy and Johnson included an extended involvement in the establishment of the Alliance for Progress in Latin America. ${ }^{237}$

Contemporaneously with the publication of The Stages of Economic Growth, Rostow began to implement his analysis in service to the U.S. government, first with Office of Strategic Services (the precursor to the CIA) during World War II, then as chairman of the policy planning council of the State Department under Presidents Kennedy and Johnson, and finally as a special assistant for national security affairs to President Johnson. Rostow's development advice quite often explicitly took into account anti-communist foreign policy objectives at the center of the Cold War. ${ }^{238}$ In this last position, Rostow served directly

236 Other influential modernization theorists included Lucian Pye, Max Milliken and Daniel Lerner. See David Steigerwald, The Paradoxes of Kennedy Liberalism, 28 Reviews in American History 636 (2000).

237 Charles Kimber Pearce, Rostow, Kennedy, and the Rhetoric of Foreign Aid (2001). Rostow and others experienced most success under Kennedy's administration, which actively sought guidance from the academy. See David Steigerwald, The Paradoxes of Kennedy Liberalism, 28 Reviews of American History 636 (2000).

238 See, e.g., Memorandum from Rostow to President Johnson, "Food Aid to Egypt" (June 18, 1966) (weighing the utility of aid to the Nasser regime in Egypt against the objective of reducing Soviet influence) (available from the Jewish Virtual Library, at http://www.jewishvirtuallibrary.org/jsource/USIsrael/frus061866.html). Also at Source: Schwar, Harriet Dashiell. (Ed.). Foreign 
under Special Assistant to the President for National Security Affairs, McGeorge Bundy. ${ }^{239}$ In this capacity, Rostow served as a primary architect of U.S. involvement in Vietnam as part of U.S. anti-communist foreign policy. ${ }^{240}$

One important initial effect of translating Rostow's theory into U.S. policy was a focus on development aid in general. Rostow succeeded in persuading the U.S. government to move towards longer-term aid to developing country governments, although efforts in this regard never matched the Marshall Plan. ${ }^{241}$ Rostow believed that the U.S. government could help to support a capitalistic framework that would enable the preconditions for takeoff - conditions conducive to entrepreneurship - to emerge. ${ }^{242}$

Relations of the United States, 1964-1968, V. 18, Arab-Israeli Dispute 1964-1967. DC: $\underline{\mathrm{GPO}}$, 2001. In the Middle East, Rostow's preeminent objective appeared to be to promote stability so as to prevent the fracturing of the Arab states into Soviet alliances. Hence Rostow also advocated pressuring Israel to make concessions to Palestinian negotiators so as to prevent a buildup of tension in the region. See Memo to President Johnson, "Rostow Urges Johnson to Pressure Israel” (January 5, 1968), at Source: "Memorandum from [Walt] Rostow to President Johnson," Smith, Louis J. (Ed.). Foreign Relations of the United States, 1964-1968, V. 20, ArabIsraeli Dispute 1967-1968. DC: GPO, 2001. and also http://www.jewishvirtuallibrary.org/jsource/US-Israel/Frus33.html. 239 There is a White House file with Rostow's correspondence while in this position. Other files are held by the University of Texas.

240 U.S., Congress, Senate, Committee on Foreign Relations, The U.S. Government and the Vietnam War: Executive and Legislative Roles and Relationships, Part II, 19611964 (Washington: U.S. Government Printing Office, 1985). (Describing W. W. Rostow as among the "foremost leaders in the development of U.S. counterinsurgency doctrine and programs" and as a leading and persistent advocate for concerted military action in Vietnam.) Chapter 1, titled "The 1961 Decision To Stand Firm In Vietnam," recounts in detail Rostow's consistent advocacy for military action in Vietnam - and in ensuring that such planning occurred without Congressional participation - from the early stages of U.S. involvement following the 1961 decline of the rightist Laotian government. 241 See, e.g, Tae-Gyun Park, W. W. Rostow and Economic Discourse in South Korea in the 1960s, 8 JOURNAL OF INTERNATIONAL AND AREA STUdIES 55 (2001), at 57-61. In fact, at the takeoff stage Rostow advocated the support of broader welfare state support. See Rostow, Stages of Economic Growth, pp.62-63.

242 Charles Kimber Pearce, Rostow, Kennedy, and the Rhetoric of Foreign Aid (2001); Michael Adamson, Social Scientists as Policymakers, Humane Studies Review Vol. 14, No. 3 ("Based on his reading of British and American economic 
With other development economists of the time, ${ }^{243}$ Rostow also endorsed "unbalanced growth" 244 - that is, a focus on supporting key industries rather than attempting to address more broadly the infrastructural and societal conditions of economic production. The unbalanced growth model operated on the assumption that accelerating growth in these key industries would create "spillover gains" that would bring the rest of the economy along - a theory that later became known as "trickle-down" economics.

Unbalanced growth policy implemented Rostow's focus on the expanding capitalist nucleus because it envisioned a core of entrepreneurs taking a leadership role in these key industries. The conception of developing societies as "dual" economies split between traditional and modern segments characterized much of the development economics of this period. This conception could be reinterpreted as yet another "example of the utility of binary thinking within a Parsonian model."245

Additionally, because it emphasized the importance of investors, this model could support the country's continued receptivity to foreign capital, and continued openness to the international marketplace. ${ }^{246}$ Moreover, U.S.

history, Rostow identified a lack of capital formation as the primary obstacle preventing poor countries from rapidly modernizing during the critical period as they emerged from colonial rule. Rostow recommended that Washington provide the requisite funds that would serve as a catalyst for the achievement of "takeoff," or rapid economic growth. "Takeoff" would lead to a period of "selfsustained growth," which would make the world's poor less inclined to foment political unrest and agitation.")

243 E.g. Albert Hirschman is among the best known of the advocates for "unbalanced growth." See Albert Hirschman, The Strategy of Economic Development (1958).

244 See, e.g, Tae-Gyun Park, W. W. Rostow and Economic Discourse in South Korea in the 1960s, 8 JOURNAL OF INTERNATIONAL AND AREA STUdIES 55, 61 (2001).

245 Gilman, Nils. Mandarins of the Future, 2004. p 83.

246 See, e.g, Tae-Gyun Park, W. W. Rostow and Economic Discourse in South Korea in the 1960s, 8 JOURNAL OF INTERNATIONAL AND AREA STUDIEs 55, 60 (2001).

("Within this approach, what kind of economic structure should be 
economic surplus could be channeled into trade, aid and investment projects in developing countries. ${ }^{247}$ Indeed, an important dynamic of the model was its role in boosting U.S. economic interests. ${ }^{248}$

An examination of Rostovian modernization theory also reveals that U.S. policy in turn affected and altered the analytical framework of modernization theory. In particular, the military and geopolitical objectives of the U.S. in this time frame led to increasingly greater emphasis on the importance of "nation-building." 249 Nation-building not only served the goal of modernization within a developing country, however, but also served the goals of regional order and stability - crucial to Cold War era U.S. policy.

In early modernization theory, nation-building and democracy-building were intertwined. ${ }^{250}$ Because nationbuilding furthered development, and under modernization theory the development of capitalistic economic growth naturally facilitated the development of democracy, it followed that nation-building would promote democracy. ${ }^{251}$

recommended? It was not to be an independent economy, but one which had a place within the international capitalist economy. On the one hand this was related to the speeded up economic development, because the Third World should continue to accept a great amount of foreign capital and various kinds of developed skills and technology.") Rostow, Milliken and Pye were particularly influential in shaping U.S. policy in Southeast Asia. See id.

247 See Rostow, The Stages of Economic Growth, at pp.93-100.

248 See Rostow, The Stages of Economic Growth at pp.6-8: The economic development program outlined in the balance of this book is conceived as one of the instruments for carrying out the task of helping create an environment within which American society can thrive.") "

249 Michael E. Latham, Modernization As Ideology: American Social Science and 'Nation-Building' in the Kennedy Era (Chapel Hill, N.C., 2000).

250 Mark T. Berger, Decolonisation, Modernisation and Nation-Building: Political Development Theory and the Appeal of Communism in Southeast Asia, 19451975, 34 Journal of Southeast Asian Studies 421, 425 (2003) ("The idea of nationhood carried withit a commitment, at least in the abstract, to democracy, human rights and universalsuffrage")

251 See, e.g., James S. Coleman, 'The political systems of the developing areas', in The politics of the developing areas, ed. Gabriel Almond and James S. Coleman (Princeton: Princeton University Press, 1960), pp. 537-9; see alsoMark T. Berger, 
A 1960 Presidential Task Force report on which Rostow collaborated outlined the intended mutual reinforcement of nation-building and democracy-building objectives: "The new aid program must recognize these motivations and provide the resource incentive for local leaders to direct nationalistic forces into constructive channels of building democratic nations. It should give support especially to the leaders who are eager to modernize society..." 252

In practice, and in keeping with the gist of "high modernism," nation-building concerns increasingly took priority often took priority over the promotion either of economic development or democracy. ${ }^{253}$ The Cold War environment meant that "order and stability were always more important than democracy as far as most modernization theorists were concerned."254 Nils Gilman writes,

Conceptualizing the passage to modernity as a brief transitional period, with political instability and the concomitant threat of Communist takeover as the main risks, many modernization theorists began to suggest that the United States should promote the most rapid possible passage through this dangerous "stage of growth" - by whatever means necessary. Ultimately, this theory would justify U.S. intervention in Vietnam

Decolonisation, Modernisation and Nation-Building: Political Development Theory and the Appeal of Communism in Southeast Asia, 1945-1975, 34 Journal of Southeast Asian Studies 421 at 429 (2003) ("Early theorists were at least rhetorically committed to democracy,often seeing it as the direct result of economic development and the key to political stability.... At the same time, this conception of political development was elitist and technocratic, and even in the 1950s stability was regarded as more important than democracy - an emphasis that would become more pronounced in the 1960s.") 252 Task Force Report, Dec. 31, 1960, National Security File(NSF): Subjects: Foreign EconomicPolicy, Box 297, John F. Kennedy Library(JFKL).

253 Stephen G. Rabe, The Most Dangerous Area in the World: John F. Kennedy Confronts Communist Revolution in Latin America (1999).

254 Mark T. Berger, Decolonisation, Modernisation and Nation-Building: Political Development Theory and the Appeal of Communism in Southeast Asia, 19451975, 34 Journal of Southeast Asian Studies 421, at 426 (2003). 
on the grounds that such action promoted

modernization. 255

The dynamics of this "reverse" influence from U.S. policy concerns back to practice became even more pronounced in subsequent strains of modernization theory. In the emphasis on modernization "by any means necessary," and the acceptability of sacrificing democratic governance towards this end, Rostovian "modernization theory would in Gilman's words "represent liberalism's entry into this hall of twentieth-century ideological horrors." 256

\section{Another Path: Moderate Parsonianism in Development Studies}

While modernization theory came to dominate much of U.S. development policy in the early postwar era, another Parsonian trajectory gained significant ground in the academy although ultimately enjoying less salient influence in the field. This strain of Parsonian analysis generally took care to retained greater analytical complexity. Although the Parsonian focus on social patterns and structures still characterized this work, these "Moderate Parsonians"

255 Nils GILMAN, MANDARINS OF THE FUtURE 12 (2004).

256 NiLs GILMAN, MANDARINS OF THE FutURE 11 (2004). Eventually, later modernization theorists like Samuel Huntington would focus on the "strong state" as the pre-eminent concern, downplaying the role of the shift in values towards the "expanding capitalist nucleus" or the supposed symbiotic emergence of political democracy. See, e.g., Samuel Huntington, Political order in changing societies (New Haven: Yale University Press, 1968);Huntington, The soldier and the state: The theory and politics of civil-military relations (Cambridge: HarvardUniversity Press, 1957); Changing patterns of military politics, ed. Samuel Huntington (New York: FreePress, 1962 "Samuel Huntington is generally seen as one of the most prominent exponents ofthe shift from classical modernisation theory, with its psychological orientation and its apparent emphasis on democracy, to the politics-of-order and military modernization theory." Mark T. Berger, Decolonisation, Modernisation and Nation-Building: Political Development Theory and the Appeal of Communism in Southeast Asia, 19451975, 34 Journal of Southeast Asian Studies 421 at 442 (2003). 
tended to eschew the sweeping cross-historical and crossgeographical conclusions of modernization theory. Perhaps not surprisingly, the political valence of this strain of development studies tended to track a more moderate liberalism, as opposed to the concertedly classical-liberal starting point of modernization theory.

A somewhat more self-critical and other-regarding sensibility seemed to characterize this more moderate Parsonianism. The focus on cultural variables arose, in part, out of the realization by these development experts while working in the field that "even though "we knew all of the answers," very few of them worked. Initially we were simply insensitive to the (1) cultural differences, (2) indigenous motivating forces, and (3) different value systems. Often one of the greatest mistakes Americans make . . . is the assumption that the response of foreigners can be predicted upon the basis of our own value system."'257 Thus, for example, an early Parsonian moderate Albert Hirschman concluded that "I set out to learn about others, and in the end learned about ourselves." 258

Certainly, Hirschman sought to establish general conclusions regarding strategies for development. In particular, Hirschman became known for the "unbalanced growth" approach to spurring industrialization, ${ }^{259}$ and its accompanying concepts of "forward" and "backward"

257 Bruce E. Seely, Historical Patterns in the Scholarship of Technology Transfer, Comparative Technology Transfer and Society 1.1 (2003) 7, at 13 (citing p. xxii of Strassor, G. (1974). Keynote address: Technology transfer revisited. In Manning, G. K. Technology Transfer: Successes and Failures (pp. xv-xxii). San Francisco: San Francisco Press; citing also Hirschman, A. O. (1967). Development Projects Observed. Washington, DC: The Brookings Institution. ). 258 Albert Hirschman, A Dissenter's Confession: The Strategy of Economic Development Revisited, in G.M. Meier and D. Seers ed., Pioneers in Development (1984).

259 Albert Hirschman, The Strategy of Economic Development, at 63-70 (defining development as a "chain of disequilibria" manifesting in a "see-saw" effect whereby concentrated growth in one sector would be followed by "catching-up" effects in other sectors. 
linkage. ${ }^{260}$ Hirschman's theories, however, moderated both the universalism and the market orientation of the modernization theorists.

Hirschman disavowed the "laissez-faire" tendencies of theorists like McLelland and Hagen. ${ }^{261}$ And, regarding integration of developing-country economies into the international marketplace, he evinced caution, warning against the dangers of "polarization effects" that might arise if developing-country economic activity became displaced by developed-country competition..$^{262}$

Although less dogmatically neoliberal than Rostow, with "unbalanced growth" Hirschman distanced himself from more emphatically Keynsian policies of demand-side development policy. ${ }^{263}$ Hirschman's approach emphasized supply-side concepts such as savings, investment and "trickling-down" effects. ${ }^{264}$ Hirschman shared the general liberal orientation and attraction to universalism of Rostow,

260 Hirschman, The Strategy of Economic Development, at 100 (defining backward linkage effects as those arising when industrial economic activity induces "attempts to supply through domestic production the inputs needed in that activity"; and defining forward linkage effects as those arising when industrial economic actors "attempt to utilize [their] outputs as inputs in some new activities.")

261 Albert Hirschman, The Strategy of Economic Development, at 2 n.3; see also Albert Hirschman, Journeys Towards Progress at 5 (1963).

262 Albert Hirschman, The Strategy of Economic Development, at 188.

263 Hirschman criticized the "balanced growth" model because it was "derived from the demand side.... It is argued [that] to make development possible it is necessary to start, at one and the same time, a large number of new industries which will be each others' clients through the purchases of their workers, employees and owners." Hirschman, The Strategy of Economic Development, at 51. Hirschman criticized this model in part because he felt it was unrealistic: "if a country were ready to apply the doctrine of balanced growth, then it would not be underdeveloped in the first place." Hirschman, The Strategy of Economic Development, at 54. The balanced growth model was associated with Paul Rosenstein-Rodan's "theory of the big push," and accordingly a somewhat more statist view of development policy and planning.

264 See Albert Hirschman, The Strategy of Economic Development, at 35-44 (focusing on the "ability to invest" and the "complementarity of investment") and 187-190 (focusing on "trickling-down" effects) 
but in more moderate form.

In fact, Hirschman rebelled against the stronger universalizing tendencies of modernization theory, seeking instead to "underline the multiplicity and creative disorder" of dynamics of growth and development. ${ }^{265}$ The overall message of The Strategy of Economic Development appeared to endorse careful case-by-case analysis over one-size-fits-all policy. ${ }^{266}$ Perhaps because of this sensibility, Hirschman's field experience included much more direct consultation for developing-country governments than that of the U.S. government-centered Rostow. ${ }^{267}$

Hirschman's understanding of Weber caused him to acknowledge the possibility of the "hiding hand"; that is the possibility of unintended consequences of development policy resulting in part from inadequate knowledge of or sensitivity to the particular interests and motives regarding economic production in a given locale. ${ }^{268}$ The "hiding hand" analysis demonstrates how the "one-size-fits-all" critique of Weber extends far beyond the normative problem of "ethnocentricity":269 "one-size-fits-all" policies are problematic from a pragmatic perspective simply because

265 Albert Hirschman, A Dissenter's Confession: The Strategy of Economic Development Revisited, in G.M. Meier and D. Seers ed., Pioneers in Development (1984).

266 Hence Hirschman's critique of the "visiting economist's syndrome," often provoked by institutional donors' demands for speedy diagnosis of and prescription for economic growth in developing countries. Albert Hirschman, A Dissenter's Confession: The Strategy of Economic Development Revisited, in G.M. Meier and D. Seers ed., Pioneers in Development (1984).

267 For a short general introduction to Hirschman's role in Latin America, and the relationship with his theories of economic development, see Ana Maria Bianchi, Albert Hirschman in Latin America: Notes on Hirschman's Trilogy on Economic Development, presented at the 9th annual European Conference on the History of Economic Thought (Conferencia Europeia de Historia do Pensamento Economico (ECHE)) (on file with author).

268 See Albert Hirschman, Development Projects Observed (1967).

269 See, e.g., David Trubek, Max Weber on Law and the Rise of Capitalism, 1972 Wisconsin L. REv. 720, 737 n.31; David Trubek \& Marc Galanter, Scholars in SelfEstrangement, 1974 WisCONSIN L. REV. 1062, 1080. 
they tend not to work well. It suggests that the transplantation of universals will fail not only because of differences in normative ideals, but also because of differences in interests and in practices.

Ultimately, Hirschman himself maintained the emphasis on the normative. One of his unique contributions to development analysis was to identify a major shortcoming in development policy as psychological: "Our diagnosis is simply that countries fail to take advantage of their development potential because, for reasons largely related to their image of change, they find it difficult to take the decisions needed for development in the required number and at the required speed."270 Later, Hirschman would supplement this psychological analysis with a description of a "failure complex" that could plague development policymakers, rooted in part by a rage de vouloir conclure. ${ }^{271}$

Hirschman's solution to this problem, however, retains something of Weber's sophisticated integration of material and ideal, normative and nonnormative. Rather than wait for psychological change to arise independently, Hirschman advised the establishment of "inducement mechanisms." Systems for engineering the interests of decisionmakers would ensure that "decisions ... will be taken because there is some extra pressure behind them as a result of pacing, routine responses, threatened penalties, certain and high profitability, or other forces." 272

While Hirschman's "social engineering" approach to development policy ultimately fell prey to criticism as well,

270 See Albert Hirschman, The Stategy of Economic Development at 25. At times, hesitation could yield to ambivalence: "While overtly considerable effort is made in a country to introduce modern methods and techniques, a vague resentment may yet exist at the same time against the new ways, a secret hope that the equipment or the methods will not work out..." Hirschman, The Strategy of Economic Development, at 138.

271 A rage of wanting to be done with it. See Hirschman, Journeys Toward Progress (1963).

272 Albert Hirschman, The Strategy of Economic Development, at 27. 
its understanding of the importance of environmental incentives to adopt economic growth strategies evinces a deeper understanding of Weber's theory of social change. Moreover, it is this understanding which ultimately served as the basis for the later critique of Hirschman and others. Former World Bank economist David Ellerman, for example, has concluded that the "social engineering" approach must fail because, in the end, "both the motivation and the knowledge are external to the doers." 273

If Rostow's "extreme" Parsonianism informed U.S. policy, the more subdued and open-ended approach of Hirschman and others, such as Gunnar Myrdal274 and Bert Hoselitz, ${ }^{275}$ found reflection elsewhere in the U.S. academy, and also tended to gravitated more towards internationalist projects. Thus, university centers emerging out of this period included not only W.W. Rostow's Center for International Studies at MIT, but also the more moderate University of Chicago's Research Center in Economic Development and Cultural Change and its accompanying journal Economic Development and Cultural Change. ${ }^{276}$ The "Chicago School" of sociology focused on detailing the complex socioeconomics of development.277 In particular, these institutions sought to correct "the early mistakes" by recognizing the "interactive nature of transfer and development activities." 278

273 David Ellerman, Rethinking Development Assistance: An Approach Based on Autonomy-Respecting Assistance, at 2 (on file with author). Indeed, Hirschman himself has endorsed Ellerman's work. [cite]

274

275

276 Bruce E. Seely, Historical Patterns in the Scholarship of Technology Transfer, Comparative Technology Transfer and Society 1.1 (2003) 7, at 13-14

277 The Chicago School of sociology features more moderate politics than its counterpart, the Chicago School of economics, which is known for adopting a more definitely neoliberal perspective.

278 Bruce E. Seely, Historical Patterns in the Scholarship of Technology Transfer, Comparative Technology Transfer and Society 1.1 (2003) 7, at 13-14 (citing to 
Despite the academic prestige and relative influence of the Moderate Parsonians, their scholarly efforts appear to have proven relatively less influential than those of the modernization theorists. According to Paul Krugman, "high development theory" of this sort failed to gain influence precisely because it embraced multidisciplinary complexity. Krugman writes,

Like it or not, the influence of ideas that have not been embalmed in models soon decays. And this was the fate of high development theory. . . . By the early 1970s (when I was a student of economics) [Hirschman and Myrdal] had come to seem not so much wrong as meaningless. What were these guys talking about? Where were the models? And so development theory was not so much rejected as simply bypassed. ${ }^{279}$

Despite Krugman's explanation, Rostow's equally unmodeled approach gained influence even while the Moderate Parsonians waned in theirs: "The most influential book on economic development to emerge from economic circles, however, was W. W. Rostow's The Stages of Economic Growth. 280 This is ironic, in light of Krugman's analysis, for ...[Rostow's] was not an economistic theory ... [ [Rostow's] economic development required not only appropriate economic, technological, and demographic conditions, but also appropriate social institutions and value systems." 281

Cleveland, H. (1960). The Overseas Americans. New York: McGraw-Hill; Sufrin, S. C. (1966). Technical Assistance - Theory and Guidelines.; especially Rosen, G. (1985). Western Economists and Eastern Societies: Agents of Change in South Asia, 1950-1970. Baltimore: The Johns Hopkins University Press. Rosenberg, N. (1970). Economic development and the transfer of technology: Some historical perspectives. Technology and Culture, 11(3), 550-75. ).

279 Quoted in Bruce E. Seely, Historical Patterns in the Scholarship of Technology Transfer, Comparative Technology Transfer and Society 1.1 (2003) 7, at 14.

280 Seely, at 15-16.

281 Seely, at 15-16. 
Perhaps the theoretical simplicity of Rostow's "unilinear" 282 conception of analysis recommended it to development economists in ways that the theoretical complexity of the Moderate Parsonians did not.

\section{Modernization and Legal Reform: Theory, Policy and Praxis}

\section{D.1. The Law and Development Movement}

This same dynamic, whereby the more thoughtful strains withdrew from the fulcrum of power, characterizes in part the wax and wane of the "law and development" movement of the 1970s. This movement originally shared many of the tenets of modernization theory.

Modernization theory incorporates the notion of a stable legal order. With respect to economic development, such a legal system is necessary particularly because it enables the predictable and effective enforcement of 'background' rules necessary for capitalist economic growth, especially contract and property rights. ${ }^{283}$

The emphasis within modernization theory of a stable legal order and the rule of law reflects Weber's own analysis of "logically formal rationality" in modern legal systems, as filtered through Parsonian evolutionary theory.

In his essay "Evolutionary universals in society," Parsons argued - Parsons applied Weber's notion of the "generalized legal order as the special hallmark of modernity" 284 to recommend legalization as a prescriptive

\footnotetext{
282 Seely, at 16 .

${ }^{283}$ For a concise exposition of modernization theory, see Kevin Davis \& Michael Trebilcock, What Role Do Legal Institutions Play in Development?, IMF Paper Series (1999), at p.13.

284 Jackson Toby, Parsons' Theory of Societal Evolution, in Talcott Parsons, The Evolution of Societies, at 1, 13 (1977).
} 
requirement for modernizing societies :

Law furthers the independence of the normative components of the societal structure from the exigencies of political and economic interests .... It is the kind of law, the institutionalization of which marks the transition from intermediate to modern societies, that poses the theoretical problem. Its organization must be generalized according to universalistic principles. This requirement precludes such imposing systems as the Talmudic law or that of traditional Islam from being classed as modern law. They lack the generality which Weber called formal rationality. 285

Parsons argued that "legalism" is "the major criterion marking the evolution of societies from 'intermediate' to 'modern'": 286 "[L]aw, when developed to the requisite level, furthers the independence of the normative components of the societal structure from the exigencies of political and economic interests and from the personal, organic, and physical-environmental factors operating through them..." 287 Thus, law must be "highly generalized according to universalistic principles." 288

This phrasing, Trubek observed, is "Weberian in

285 Talcott Parsons, Societies: Evolutionary and Comparative Perspectives 27 (1966). See also Talcott Parsons, Evolutionary Universals in Society, 29 American Sociological Review 339 (1964). In Societies: Evolutionary and Comparative Perspectives, Parsons also emphasized the importance of procedure: "Modern legal systems must also emphasize the factor of procedure, as distinguished from substantive precepts and standards. Only on the basis of procedural primacy can the system cope with a variety of changing circumstances and cases without prior commitment to specific solutions."

286 David Trubek, Max Weber on Law and the Rise of Capitalism, 1972 WisCONSIN L. REV. 720, 737 n.31.

287 p.27, Talcott Parsons, Societies: Evolutionary and Comparative Perspectives (1966) (cited in David Trubek, Max Weber on Law and the Rise of Capitalism, 1972 WisCONSIN L. REV. 720, 737 n.31).

288 p.27, Talcott Parsons, Societies: Evolutionary and Comparative Perspectives (1966) (cited in David Trubek, Max Weber on Law and the Rise of Capitalism, 1972 WisCONSIN L. REV. 720, 737 n.31). 
inspiration and characteristically Parsonian in its abstractness." 289 In his analysis of legal reform, as elsewhere in his work, Parsons transposes Weber's historical, heuristic analysis onto the prescriptive frame of modernization theory. ${ }^{290}$ By "link[ing] the concept of modernity to societies that develop autonomous legal orders," Parsons appears to "den[y] the possibility of 'modernization' without 'legalism.'” 291

The role of legalization within Parsonian theory helped to generate the impetus for legal reforms as a part of U.S. foreign policy in the mid-twentieth century. The "rule of law" became an important part of the framework adopted by the U.S. "foreign policy establishment" early in the post-World War II emergence of the U.S. as a leader in the international community. ${ }^{292}$ The question of "legal development" attracted significant support from the U.S. government and U.S. foundations from the 1950s onward. 293 Legal scholars joined into the already-ongoing efforts of the

289 David Trubek, Max Weber on Law and the Rise of Capitalism, 1972 WISCONSIN L. REV. 720, 737 n.31.

290 David Trubek, Max Weber on Law and the Rise of Capitalism, 1972 WisCONSIN L. REV. 720, 737 n.31: "Parsons has taken over, at a very superficial level, the Weberian analysis, but has generalized it to all societies, making the development of logically formal rationality a criterion of modernity." 291 David Trubek, Max Weber on Law and the Rise of Capitalism, 1972 WisCONSIN L. REV. 720, 737 n.31.

292 David Trubek \& Marc Galanter, Scholars in Self-Estrangement, 1974 WISCONSIN L. REV. 1062, 1087. See id., p.1067: “Given the political and intellectual climate of the time, it is no wonder that... '[d]evelopment' was in the air: liberal America was excited by the prospect of harnessing American knowledge and resources to the developmental task." See also Robert A. Packenham, Approaches to the Study of Political Development, 17 World Politics 108, 109 \& n.6 (1964) (describing the "legal-formal" approach to development to be the "dominant preoccupation of American political scientists at least until 1950.") 293 See David Trubek \& Marc Galanter, Scholars in Self-Estrangement, 1974 WisCONSIN L. REV. 1062, 1066 \& n.13 (describing the emergence of this support and leading programs supported by the U.S. Agency for International Development and non-governmental bodies such as the Ford Foundation). 
social science departments in the field. ${ }^{294}$ These "lawyers and academics adopted Max Weber's legalism as the appropriate model for developing societies." 295

Legal reform efforts tended to focus on two primary areas. The first was legal education. Training local legal professionals seemed to go to the heart of the matter, since such professionals could then go on to design and operate formal-rational legal systems. ${ }^{296}$ The legal-education effort involved academics from elite American law schools working with governmental and private funding sources to design programs for the reform of legal training in developing countries toward the instrumentalist (or realist) sensibility of American-style "legal liberalism." 297

A second emphasis fell upon judicial reform specifically. The American model of legalism "celebrated courts as the core of the legal order." 298 The International Commission of Jurists, for example, issued a report in 1959 entitled "The Rule of Law in a Free Society," declaring the centrality of "individual rights and the administration of justice in national societies." 299 This body continued to

294 David Trubek \& Marc Galanter, Scholars in Self-Estrangement, 1974 WISCONSIN L. REV. 1062, 1065 ("The lawyers were latecomers to the development research game, responding more slowly than social scientists to the demand for theoretical insights into the processes of development.") 295 p.199, Robert B. Seidman, The State, Law and Development (1978). 296 See Davis \& Trebilcock, at p.14 ("the [law and development] movement adopted a top-down approach" and "emphasized the reform of legal education... The assumption was that lawyers trained to use the rule of law as an instrument for change would promote the development goals of the state.") See also David Trubek \& Marc Galanter, Scholars in Self-Estrangement, 1974 WiSCONSIN L. REV. 1062, 1075-1076 ("by training lawyers to think more instrumentally, [law] schools could intiate change that would narrow the gap between ... specific legal rules, doctrines and procedures on the one hand, and national developmental goals on the other.")

297 Cf. David Trubek \& Marc Galanter, Scholars in Self-Estrangement, 1974

WiSCONSIN L. REV. 1062, 1075-1076.

298 RoBert B. SEIDMAN, THE STATE, LAW AND DEVELOPMENT 199 (1978).

299 International Commission of Jurists, The Rule of Law in a Free Society, at p.326 (1959) (cited in John H. Spencer, Review, Executive Action and the Rule of Law: A Report on the Proceedings of the International Congress of Jurists, Rio de 
study the challenges posed to developing formal systems of adjudication in developing countries throughout the 1960s. 300

The law and development movement translated modernization theory's basic approach into the particular language of the "liberal legalism" of the United States legal elite. The liberal legalism paradigm adopted the following general assumptions:

- It "focused on higher agencies of the legal system" as opposed to "nonstate forms of legal or other social ordering";

- It "manifested a pervasive belief in the ultimate efficacy of legal rules as instruments of social change," emphasizing the "instrumental relationship between development goals and specific legal rules";

- It "assumed that legal professions were, or could be, representative of the public interest"; and

- It "took for granted the existence of some natural tendency for legal systems in the Third World to evolve in the direction of [this] ideal model of liberal legalism." 301

These assumptions led the assistance effort to "focus on reform of formal rules, to work with the established professions, to believe that changes in the educatin of the

Janeiro, 1962, in 61 Am. J. Int'1 L. 839, 840 (1967).

300 See, e.g., Executive Action and the Rule of Law: A Report on the Proceedings of the International Congress of Jurists, Rio de Janeiro, 1962; The Dynamic Aspects of Rule of Law in the Modern Age: Report o the Proceedings of the South-East Asian and Pacific Conferences of Jurists, Bangkok, Thailand, 1965. ${ }^{301}$ David Trubek \& Marc Galanter, Scholars in Self-Estrangement, 1974 WISCONSIN L. ReV. 1062, 1079. 
professional legal class would ultimately produce desired social change and, above all, to assume almost automatically that any activity that was designed to change legal institutions of Third World countries to make them more like those of the United States would be an effective and extremely worthy pursuit." 302

Law and development reform soon atrophied as a basis for U.S. intervention, however. One factor was the theoretical ascendancy of "big push" economic development theory, which viewed law as purely instrumental to implement industrialization policies, rather than as an end in itself. ${ }^{303}$ Big-push and other economic development theories of this era found popularity and embrace amongst developing-country governments. ${ }^{304}$

Another factor was undoubtedly the waning official support within the U.S. foreign policy establishment. With the rise of the Non-Alignment Movement of developing countries in the 1970s, however, the ability of U.S. foreign policy to effectuate this kind of law reform waned. In the Cold War context, with the Soviet Union competing for alliances, and with the adoption of much of the developing world of nationalist/socialist government, the attention to implementing liberal reforms in the domestic legal systems of developing countries fell away. 305

302 David Trubek \& Marc Galanter, Scholars in Self-Estrangement, 1974 WISCONSIN L. Rev. 1062, 1079-1080.

303 Cf. Robert Packenham, Approaches to the Study of Political Development, 17 World Politics 108, 110 (1964) ("one of the most notable characteristics of studies of the politics of developing areas is how far the pendulum has swung away from legal-formal to economic, administrative, sociological, and psychological factors as explanatory variables.") 304

305 Eric Neumayer, “The infamous Cold War saying, 'We know they are bastards, but at least they are our bastards, not theirs,' which justified much support to Cold War allies in spite of a bad governance record, fell out of fashion with the Berlin wall." Neumayer, at p.1, The Pattern of Aid Giving (2003). [CITE - U.S. foreign policy during this era was a hodge podge of strategies designed to 
D.2. Another Path: Scholars in Self-Estrangement from Law and Development's Theoretical Shortcuts

A final cause in the decline of the law and development movement was a loss of confidence by the movement's intellectual authors. This experiential transformation is memorably recounted in the essay by David Trubek \& Marc Galanter entitled, "Scholars in SelfEstrangement." 306 Widely read among legal scholars interested in development, this article described the misgivings about the law and development movement that caused its proponents within the legal academy to withdraw from efforts at programmatic implementation of legal reforms in developing countries.

Though not described in terms of the "Three Theoretical Shortcuts" formulation employed here, "Scholars in Self-Estrangement" nevertheless identified the same set of conceptual shortcomings in the law and development framework.

\section{“Theoretical Shortcut \#1 ("One-Size-Fits-All”).}

Trubek and Galanter explained at length the problems arising from the universalizing assumptions in "liberal legalism's model of law in society." 307

Where "liberal legalism" assumed "social and

contain the Soviet Union: seeking explicitly or clandestinely to overturn socialist governments such as those in Chile and Guatemala, tolerating nationalist, statist and totalitarian regimes where they were open to alliance with the U.S., such as that in Egypt. U.S. advocacy of liberal legal values tended to limit itself to disputes arising in an explicitly transnational context, such as nationalizations of property owned by foreign investors.]

306

307 David Trubek \& Marc Galanter, Scholars in Self-Estrangement, 1974 WISCONSIN L. REV. 1062, 1080. 
political pluralism," Trubek \& Galanter found instead "social stratification and class cleavage" in "most of the Third World." 308 Where liberal legalism assumed that "rules reflect the interests of the vast majority of citizens and are normally internalized by them," the authors found instead that "rules are imposed on the many by the few and are frequently honored much more in the breach than in the observance." 309 Where liberal legalism assumed that "courts are central actors in social control, and that they are relatively autonomous," instead "in many nations courts are neither very independent nor very important." 310

Trubek and Galanter's continued engagement with the model of liberal legalism caused them to "doubt that the model accurately describes legal life even in the United States." 311 Rather than "general" rules, "many of the rules"

308 David Trubek \& Marc Galanter, Scholars in Self-Estrangement, 1974 WISCONSIN L. REV. 1062, 1080.

309 David Trubek \& Marc Galanter, Scholars in Self-Estrangement, 1974 WISCONSIN L. REV. 1062, 1081.

310 David Trubek \& Marc Galanter, Scholars in Self-Estrangement, 1974 WISCONSIN L. REV. 1062, 1081. An related critique from the authors' colleague Bob Seidman came from the perception that courts had become marginal in the process of instrumentalizing and implementing development measures. Robert Seidman observed in the context of African judicial reform, for example, that even those courts that had taken on characteristics of the rule of law "barely involved themselves in development," instead focusing on the settlement of private disputes. ${ }^{310}$ Though this role would probably suffice in today's understanding of the relationship of the judiciary to law and development, the view of that time of law-in-action appeared to contemplate a more active judicial role in the ambitious industrialization policies of the era. "Institutions that can impose only punishments with rigid, complex, and slow procedures, that can only institute incremental change, subject to rules in legalese, always at overload, and lacking expertise to deal with technical matters, will not implement many development rules. Those characterize at best, rule-applying institutions not problem-solving ones. Development, however, required change-oriented, problem-solving institutions to induce new behavior in a wide range of clients. The efforts of lawyers to ensure that the courts systems of Africa matched the ideal-type demanded by the Rule of Law missed the mark of development." Seidman, State Law and Development, at 218.

311 David Trubek \& Marc Galanter, Scholars in Self-Estrangement, 1974 WISCONSIN L. REV. 1062, 1081. 
in U.S. law "originate from, and primarily serve, specific groups"; and moreover "those who apply rules have substantial discretion... to favor certain groups and viewpoints." 312 Similarly, the "centrality of the courts is also largely mythical" in light of the fact that "regulatory activity and the promulgation of rules take place mostly in other settings." 313

In adopting this universalistic paradigm, liberal legalism employed a "one-size-fits-all" approach assumed the desirability of a single set of reform goals. In addition to being "ethnocentric," 314 such an approach was also "naïve" 315 in that perilously ignored important differences across societies that could jeopardize particular reform efforts. 316

Theoretical Shortcut \#2: The Determinism of Values. On its face, the model of liberal legalism focused on implementing specific institutional reforms through the courts and legal education. Although it did not explicitly prioritize a shift in values, it certainly envisioned that a general shift towards rationally instrumental thinking and behavior would flow from its reforms. ${ }^{317}$ Moreover, such

312 Id. at 1081.

313 Id. at 1081.

314 Id. at 1080. The charge of ethnocentricity was also implied in Unger's critique of the conception of logically formal rationality in law as essential to modernity as a particularistic result of specific history of Europe. ROBERTO M. UNGER, LAW IN MODERN SOCIETY, Chapter 3 (1977).

315 David Trubek \& Marc Galanter, Scholars in Self-Estrangement, 1974 WISCONSIN L. REV. 1062, 1080.

316 Based on this account, the assumptions of the law and development movement may also have misapprehended the logic internal to their own theoretical precursors in modernization theory, in that it appeared to assume that the very social phenomena that it was trying to create - courts, highly skilled and publicly-interested legal professionals - were already sufficiently in place as to be able to aid in the application of reform efforts.

317 David Trubek \& Marc Galanter, Scholars in Self-Estrangement, 1974 WISCONSIN L. REv. 1062, 1075 ("by training lawyers to think more instrumentally, the schools could initiate change that would narrow the gap between the present 
reforms would further the "ultimate values" (in Parsonian terms) of "liberty, equality, participation and rationality." 318

Trubek and Galanter noticed and objected to a more subtle normative dynamic within this framework: the identification of practices that constituted "counterinstances" to the "paradigm" to be "labell[ed] as deviant and therefore "bad."'319 Trubek and Galanter stop short of the charge that the prioritization of instrumental and ultimate values reflective of the liberal legal paradigm as "good" and marginalization of others as "bad" amounted to a judgment that Third World societies were underdeveloped because of "bad values." In making the charge of "ethnocentrism," however, Trubek and Galanter go some ways towards implying this very dynamic. The "bad values" upshot of "value determinism" would resurface more explicitly in the much later writings of Good Governance Scholars. ${ }^{320}$

Theoretical Shortcut \#3: Correlation between modernity and democracy. The "most serious" defect of liberal legalism in the law and development movement, according to Trubek and Galanter, was its failure to recognize that "the formal neutrality of the legal system is not incompatible with the use of law as a tool to further domination by elite groups." 321 The law and development movement began by believing that its reform efforts would necessarily promote democratic goals. ${ }^{322}$ "While the

performance of the legal profession and its developmental possibilities").

$318 \mathrm{Id}$. at 1076.

$319 \mathrm{Id}$. at 1082.

320

321 David Trubek \& Marc Galanter, Scholars in Self-Estrangement, 1974 WISCONSIN

L. REV. 1062, 1083.

322 Id. at 1064: "Legal development assistance was originally justified as a rational and effective method to protect individual freedom, expand citizen participation in decisionmaking, enhance social equality, and increase the capacity of all citizens rationally to control events and shape social life." 
assistance agencies consistently maintained that the legal development projects they supported were achieving these goals, many scholars began to wonder...." 323 The disproportionate access of the wealthy to the legal system, and the "natural" conservatism of the legal professions, often seemed to undermine rather than to further the processes of democratic change. ${ }^{324}$

This realization reflects the Theoretical Shortcut of simplifying the relationship between modernization and democracy. As Trubek and Galanter found, the process is far from straightforward. Rather, and bearing out Weber's initial analyses, it may require concerted effort against the process of legal rationalization and its accompanying entrenchment of bureaucratic hierarchy.

\section{E. The Revival of "Law and Development": The Good Governance Era}

During the 1970s, legal reform as a focus of development discourse entered into a phase of dormancy. The withdrawal of law and development scholars from legal reform efforts, coupled with the geopolitical and economic dynamics of international relations during that era, ${ }^{325}$ chilled efforts by the U.S. foreign policy establishment to achieve the "rule of law" as part of modernization in developing countries.

With the deep economic contractions that wracked

323 David Trubek \& Marc Galanter, Scholars in Self-Estrangement, 1974 WISCONSIN L. REV. 1062, 1064.

324 David Trubek \& Marc Galanter, Scholars in Self-Estrangement, 1974 WISCONSIN L. ReV. 1062, 1084.

325 Among these dynamics were the relative ascendancy of the developing world signaled by the Non-Aligned Movement and the OPEC oil strikes, and the accompanying bid by many developing-country governments to reorder international law to accommodate nationalist-socialist economic and legal systems. 
many leading developing country governments in the early 1980s, the era of reconciliation of the developing world to the liberal vision began. The 1980s saw the emergence of the "Washington consensus:" endorsement of economic liberalization shared by the U.S. government and by such international financial institutions as the International Monetary Fund and the World Bank. The IMF, the World Bank, and the GATT were during this period able to procure agreement from developing country governments to fundamental policy shifts in the direction of traditional liberalism. The IMF and World Bank policies of "conditionality" of funds on "structural adjustment," such as liberalizing trade and investment policy, privatizing stateowned economic actors, and reducing social spending, were joined by the commencement of negotiations that would result ultimately in the reinforcement of trade liberalization through the establishment of the World Trade Organization. 326

It was during this period of reconciliation of the developing world to the liberal vision ${ }^{327}$ that the focus of the "foreign policy establishment" began to shift back to law reform. "Good governance" policy articulated the legal and administrative dimensions of this larger set of liberalization reforms. 328

In its "first generation" of reforms, good governance policy focused primarily on the reform of the legal and regulatory systems for the administration of private law and public fiscal and financial law.329 This reform would be achieved, first, by bringing such systems into compliance

326 [cite AM U ILR article]

327 [Haggard calls this Deep Integration]

328 James Gathii, Retelling Good Governance Narratives on Africa's Economic And Political Predicaments: Continuities and Discontinuities In Legal Outcomes Between Markets And States, 45 Vill. L. Rev. 971, 1000-1001 (2000).

${ }^{329}$ I employ the terminology of Kerry Rittich's The Future of Law and Development, 26 Mich. J. Int'l L. 199, 206 (2004). 
with an internationally established code of "best practices," creating regularization both domestically and internationally through the transnational harmonization according to such practices. ${ }^{330}$ Second, such reforms would be achieved by emphasizing accountability and transparency within these harmonized systems. In particular, "anti-corruption" reforms would ensure systemic allegiance to the principle of the rule of law. 331

In this initial iteration, "good governance" policy explicitly avoided the realm of democratic politics, on the grounds that the expertise of the advising institutions was merely "economic" and not "political." 332 The "second generation" of good governance reforms, however, has recognized this distinction as a false one: good governance policy now explicitly recognizes the importance of democratic participation in governance reform, particularly through the incorporation of "civil society" into the decisionmaking and reform process. 333

The Connection Between Weberian Thought and Good Governance Policy

One of the leading architects of contemporary good governance theory, Ibrahim Shihata, explicitly articulated its Weberian intellectual heritage in essays such as The World Bank and "Governance" Issues in Its Borrowing Members. 334

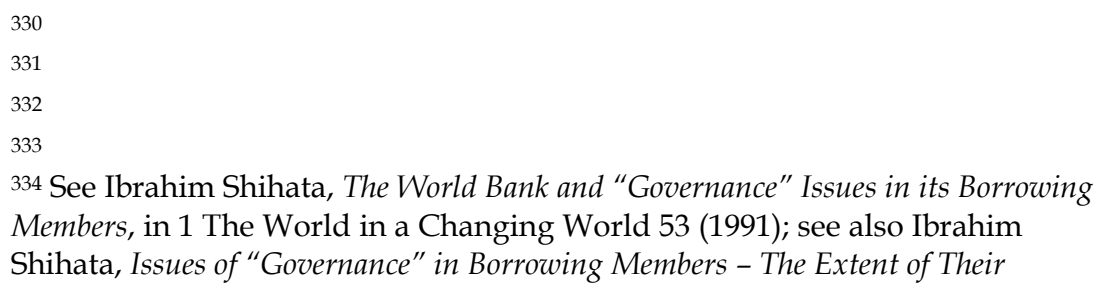


Alvaro Santos has observed that in arguing that "good governance" primarily meant the "rule of law," Shihata "referred to Weber's ideal type of 'logically formal rationality'... in a modern state as conducive to economic growth." 335

This application of Weberian theory also revealed the indebtedness of Shihata and others to a particular understanding of it, that of the modernization theorists as inherited from Talcott Parsons. The conversion of Weber's historical discussion to a prescriptive formula, and the focus of that formula on a single, universal solution to the challenge of economic development, bore the distinctive imprint of modernization theorists. ${ }^{336}$ Indeed, the focus on abstracting governance "functions" from political and societal contexts is part of the Parsonian inheritance of "global governance" scholarship more generally. ${ }^{337}$

It is the objective of this paper to argue that these concerns stem not just from ad hoc formulations of the actors and agencies involved. Rather, the specific kinds of shortcomings identified by the Good Governance are intrinsically linked to the theoretical and analytical framework bequeathed by Parsonian StructuralFunctionalism and of Modernization Theory. The remainder of this section shows how the concerns raised by the Good Governance Scholars track the Three Theoretical Shortcuts

Relevance under the Bank's Articles of Agreement, in The World Bank Legal Papers 245, 268 (2000). I am indebted to Alvaro Santos for his investigation of these sources and their link to Weberian theory. See Alvaro Santos, The World Bank's Uses of the 'Rule of Law' Promise in Economic Development, in Kennedy \& Trubek eds., at 216, 229-234.

335 See Santos, supra, at 230.

336 Cf. James Gathii, James Gathii, Retelling Good Governance Narratives on Africa's Economic And Political Predicaments: Continuities and Discontinuities In Legal Outcomes Between Markets And States, 45 Vill. L. Rev. 971, 1000-1002 (2000).

337 Robert Latham, Politics in a Floating World: Toward a Critique of Global Governance, in Martin Hewson \& Timothy Sinclair eds., APPROACHES TO GLOBAL GOVERNANCE THEORY 23, 31-35 (1999). 
traced in the foregoing genaeology.

\section{Theoretical Shortcut \#1: One-Size-Fits-All}

The tendency of good governance policy to produce a single set of recommended reforms, regardless of political or social context, has generated wide-ranging concerns amongst Good Governance Scholars. In a discussion of the IMF-sponsored drive towards "building a legal architecture for global markets" through the "harmonization of law around the globe by way of developing legal standards," for example, Katerina Pistor "questions the assumption that legal harmonization will result in the improvement of legal institutions." 338 Addressing standardization initiatives across several areas of law including "accounting, auditing, bankruptcy, corporate governance, insurance regulation and securities market regulation," 339 Pistor notes that the desire standardization effort arises out of the desire to achieve efficiency through increased certainty and uniformity. ${ }^{340}$ Pistor notes the crucial downside of such efforts, however: "Even if it were possible to design the perfect law or to develop the best standards for a particular area of the law, the incorporation of this law into a domestic legal system is per se not a guarantee for it to become effective." 341

Noting the "interdependence of legal rules and the

\footnotetext{
338 p.1, Katharina Pistor, The Standardization of Law and Its Effect on Developing Economies, G-24 Discussion Paper Series, Research Paper for the Intergovernmental Group of Twenty-Four on International Monetary Affairs, No.4, June 2000, United Nations.

339 P.3, Pistor Paper. Examples were guidelines developed by the International Federation of Accountants (IFAC), the International Association of Insurance Supervisors (IAIS), the International Organization of Securities Commissions (IOSCO), the United Nations Commission on International Trade Law (UNCITRAL) including its Model Law on Cross-Border Insolvency, and the OECD including its Principles of Corporate Governance. See id.

340 Pistor paper at 4.

341 Pistor paper at 5.
} 
characteristic of law as a 'cognitive institution,'" 342 Pistor concludes that "the process of law-making, the compatibility of the new rules with pre-existing ones as well as with given economic and political conditions, and the existence of constituencies with a demand for these rules is more important than the contents of the supplied rules." 343 The general quality of harmonized legal standards leaves open many questions that must then be resolved particularistically. For example, the OECD Principles of Corporate Governance do not specify the appropriate means for resolving conflicts between shareholders and other "stakeholders." 344 Proposals for securities harmonization assume a political system and governance framework compatible with such liquid capital markets. ${ }^{345}$ In these and numerous other ways, the harmonization effort only prompts, rather than resolves, the political and institutional challenges associated with governance in a particular context. Since standardized provisions can only acquire meaning "by relating them to pre-existing legal concepts, or interpreting them from scratch... the process of standardization defeats its very purpose."346 Ultimately, Pistor "warns against viewing legal standards as a panacea for building effective legal systems around the world."347

The importance of contextually specific analysis and application emerges as one of the conclusions of Kevin Davis and Michael Trebilcock in their sweeping review of empirical studies of the relationship between legal reform and economic development. Davis and Trebilcock note that the empirical data, though far from conclusive and

\footnotetext{
342 Pistor paper at 8.

343 Pistor paper at 5.

344 Pistor paper at 14 (considering employee codetermination and affiliated owners).

345 Pistor paper at 12.

346 Pistor paper at 17.

347 Pistor paper at 17.
} 
methodologically potentially questionable, ${ }^{348}$ do suggest a "weak" correlation between some of the major tenets of "good governance" reform such as establishing a formal system for contract enforcement. ${ }^{349}$ The authors caution, however, that the application of this tenet, as with many others in legal reform projects, through exclusive emphasis on judicial and court reform runs the risk of ignoring other modalities of governance that may be equally important in a given context. 350

Equally importantly, legal reform projects too often, in the opinion of the authors, ignore the far more challenging step of translating such broad policies into concrete administrative support. ${ }^{351}$ The focus of legal reforms on establishing particular content, such as contract enforcement, and obtaining general qualities, such as transparency, too often somehow overlooks the extensive and fine-grained overhaul of local administrative technologies required to achieve such objectives. ${ }^{352}$

348 See infra, referring to the subjective assessments that form the basis of many of these studies.

349 See Kevin Davis \& Michael Trebilcock, What Role Do Legal Institutions Play in Development?, IMF Paper Series 52 (1999) ("There is no conclusive evidence one way or another on the relative efficiency of informal and formal methods of contract enforcement. However, at the aggregate level the available evidence weakly supports some broad generalizations.")

350 See id. At 9 (concluding generally that "an exclusive or predominant preoccupation with the court system inappropriately discounts the important role played by government departments and agencies and specialized administrative or regulatory bodies in the administration and enforcement of laws").

351 See id. ("the much more daunting challenge has proven to be that of enhancing the quality of institutions charged with the responsibility for enacting laws and regulations and institutions charged with the subsequent administration and/or enforcement of those laws or regulations."). 352 Cf. Chantal Thomas, Transfer of Technology in the Contemporary International Order, 22 Fordham International Law Journal 2096 (1999) (discussing contemporary reforms in international intellectual property and environmental law and concluding that "broad areas persist in which the Bretton Woods model for technology transfer falls short, and in which greater oversight 
Theoretical Shortcut \#2: The Determinism of "Values"

Good Governance Scholars have also questioned the degree to which contemporary legal reform projects may unwittingly be assuming that poor countries remain so because of inappropriate values. Such questions have been raised in particular about the "anti-corruption" wing of good governance reform efforts.

Through a Weberian lens, the anti-corruption focus can be understood as a desire to bring the state more into conformity with the goal of formal rationalism. Corruption distorts the rational decision-making processes of the state by serving individual interests at the expense of efficient and transparent administration. As such, the beneficial impact of reducing corruption in government is self-evident.

Critics of anti-corruption reforms have charged, however, that in effect they are expressions of a belief that people in poor countries have irrational values or corrupt values. James Gathii, for example, has detailed extensively the way in which "[g]ood governance accounts demonstrate a significant distrust of African leadership." 353 Gathii provides an historical genaeology of conceptions by modern Western theorists of Africa as irrational and immoral. ${ }^{354}$ Such simplistic assumptions about the "inherent" values of Western versus non-Western cultures can, in turn, lead to an inability to perceive corruption in the West. ${ }^{355}$

of technology transfer is needed even in a liberalized regime. Paradoxically, some of these areas arise out of the very changes in the international economic order that eliminated the old technology transfer model. These changes have created implementation costs and a general need for technology necessary to administer increased international trade, finance, information, and intellectual property flows.")

353 Gathii, supra, at 1008 .

354 Gathii, supra, at 975-985.

355 David Kennedy, The International Anti-Corruption Campaign, 14 Conn. J. Int'1 L. 455 (1999) (summarizing concerns about anti-corruption, inter alia, as follows: 
This value determinism leads to a self-reinforcing perception amongst development analysts. Poor countries are assumed to have irrational values and informal governance, and their irrational values and informal governance are then assumed to cause their poverty. This circularity is a serious flaw in the methodology of much good governance reform analysis. This work produces "quantitative" or "empirical" studies of the relationship between the rule of law or corruption, on the one hand, and economic growth, on the other; but the assessments of rule of law or corruption in the measured countries are often based on subjective judgments. ${ }^{356}$ In particular, the World Bank's Governance Indicators, which are widely read and widely applied in the Bank's own policy work, ${ }^{357}$ are drawn from surveys of individual persons' perceptions. ${ }^{358}$ While recent studies have endeavored to broaden the geographical sourcing for such surveys, the majority of the perceptions

First, the claim that the anti-corruption campaign is the product of a double standard by the West against the rest - the normal lobbying and campaign financing practices of Washington law firms are seen as corruption when undertaken by members of leading families of Pakistan or Indonesia. Second, the anti-corruption campaign puts pressure on public practices in the Third World which are no different from the private practices of individuals and corporations in the First World. Imelda Marcos's shoes are a scandal, but Bill Gates' house is simply part of the idiosyncratic lifestyle of the rich and famous.") 356 See, e.g., Davis \& Trebilcock, supra, at 53 ("The difficulty with those studies [on formal contract enforcement and economic growth] is that they all rely upon subjective assessments of the likelihood of government repudiation of contracts and the overall level of law and order....").

measures of the effectiveness with which contracts are enforced.").

357 See Alvaro Santos, supra.

358 Daniel Kaufmann, Aart Kraay, \& Massimo Mastruzzi, Governance Matters

IV:

Governance Indicators for 1996-2004 (World Bank, May 2005) (presenting "aggregate governance indicators" measuring "i) Voice and Accountability; ii) Political Instability and Violence; iii)

Government Effectiveness; iv) Regulatory Quality; v) Rule of Law, and, vi)

Control of

Corruption" for "209 countries and territories," and based "individual variables measuring perceptions of governance, drawn from 37 separate data sources constructed by 31 different organizations"). 
measured still originate from Western countries. ${ }^{359}$

Related to the idea that people in poor countries have irrational or corrupt values is the idea that Western systems have become successful due to superior values, an imperialist overtone in some anti-corruption efforts. ${ }^{360}$ This leads to a lack of respect for local ways of doing things and local values, on the assumption that such ways are inherently flawed. ${ }^{361}$ One result can be reforms and processes that ignore local considerations and therefore are perceived as illegitimate. When combined with an insufficient attention to power dynamics, the result can be disastrous as discussed below. ${ }^{362}$ Also related to the idea that people in poor countries have irrational or corrupt values is the idea that development can only after such values have changed. ${ }^{363}$ As the Rostovian and culture and development perspectives described above suggest, the single biggest requirement for development in poor societies is that the culture embraces the "Protestant" values required for capitalistic economic growth.

This critique picks up on the relationship between normative and non-normative interests discussed above. To be sure, Weber in the Protestant Ethic described valuerational behavior associated with Calvinism as critical in producing the phenomenon of American capitalism. The idea that the West succeeded economically because it had superior values is probably most commonly associated with Weber's work in Protestant Ethic. As the discussion above indicates, however, Weber's understanding of social action and governance, including their manifestations in the

359 Id.

360 See, e.g., Lawrence Harrison, Underdevelopment is a State of Mind: The Latin American Case (1985).

361 See for example the literature relating to "informal" contract enforcement mechanisms, e.g., in Trebilcock \& Davis at 50-53.

362 Infra discussion of privatization cases.

363 See Harrison, supra. 
modern West, was ultimately more complex. To begin with, according to one of his biographers, Weber himself explicitly rejected the idea of cultural inferiority, and criticized the Social Darwinists of his day who sought to explain differences in levels of development across societies in such terms. 364

Defenders of good governance policy would undoubtedly argue that the charges of cultural imperialism misunderstand the project, and align themselves with Weber's egalitarianism on this point. Just as Weber pointed out that certain values were more amenable to capitalism from a descriptive rather than normative point of view, any endorsement of values in good governance policy would presumably be understood as purely instrumentalist: adopted for their productive effects rather than for their normative superiority.

The critique of cultural imperialism is not only that it focuses on so-called Western values above others, but also that it focuses on values at the expense of other dynamics that play a role in development. Social action is characterized by material interests as well as ideals, and value-rational behavior is only one kind of social action. Consequently, development - including the development of law and administration through "good governance" requires much more than a shift in values.

This critique reflects the elision of material interests in

364 JOHN PATRICK Diggins, MAx Weber: POLITICS AND THE SPIRIT OF TRAGEDY 35 (1996): “[Weber] assumed that there could be no transcendant standard by which cultures could be judged superior and inferior." As an example of this view Diggins cites Weber's statement in his essay on "Churches and Sects" regarding Mormons and Indians in Utah: "[O]ne person may assert that the... material and other accomplishments and characteristics which the Mormons brought there and developed are a proof of the superiority of the Mormons over the Indians, while another person ... may prefer the desert and the romantic existence of the Indians. No science of any kind can purport to be able to dissuade these persons from their respective views." Aside from its romanticism of the Indians, this statement appears to be a fairly strong version of cultural relativism rather than cultural imperialism. 
the streamlined version of Weberian and post-Weberian thought. Would Weber himself support an idea that values have to shift in order for development to be attained? Weber did not approach his study of non-Western societies with a reformer's eye. His objective was to provide accurate and analytical description, rather than prescription. Weber did, however, concern himself with the economic development of his native Germany. Indeed, after writing the Protestant Ethic Weber expressed strong misgivings about the ability of Germany to compete with the industrious Americans. 365

In proposing a course of action for Germany, however, Weber never suggested that Calvinist values be transposed. Rather, he sought to identify concrete institutional reforms that might have the effect of spurring German society into more effective growth through the strengthening of the bourgeoisie. The proposed reforms did not seek to replicate the institutional and legal characteristics of American society, but rather were designed to address what Weber saw as the specific weaknesses of German society - the overweening power of the executive and the relative influence of the quasi-feudal agrarian elite. 366

In this vein, good governance reforms might be said to do the same: propose institutional reforms that can help to create an "entrepreneurial class." Weber was an avowed supporter of the bourgeoisie, and certainly the focus within modernization theory and good governance policy on the "capitalist" nucleus rightfully claims a Weberian pedigree. Yet Weber's own thoughts about how to generate such activity in his home country showed that he rejected both (1) the idea that a shift in values was necessary, and that (2) the system of the model country could be unproblematically transplanted. In this sense Weber rejected some of the tendencies of the discourses discussed above. Although he

365 [CITE]

$366[\mathrm{CITE}]$ 
was frustrated by the "values" of the Junkers, for example, Weber did not prescribe a shift in values but rather institutional mechanisms designed to counterbalance the influence of the Junkers - such as, direct election of the President by the people instead of the legislature.

This is, in fact, the objective of good governance reform. Where good governance can continue to improve in achieving its stated objectives, therefore, would be to avoid sliding into a simplistic one-size-fits-all approach on the one hand, or to slip into simplistic value-deterministic approach, on the other.

A final upshot of "value determinism" lies in the centrality of the entrepreneurial class to governance models of development. While a focus on the entrepreneurial class characterizes both Weber's thought and the modernization/good governance approach, one speculates whether Weber's awareness of the role of material conditions might have caused him to doubt whether legal reform should be the focus of development policy. Weber simply did not address the question of how materially underdeveloped societies might achieve industrialization however (his sole reform project being Germany).

Contemporary good governance reform picks up the emphasis of modernization theory on creating a "capitalist nucleus," in particular through multinational corporations and foreign direct investment. ${ }^{367}$ The critiques of this focus are multilayered. Some empirical data show support for the hypothesized positive relationship between capital inflows and foreign direct investment, on the one hand, and growth, on the other. ${ }^{368}$ The associated dynamics and distributional consequences of this dynamic, nevertheless, have led to

367 See Brett L. Billet, Modernization Theory and Economic Development: Discontent in the Developing World (1993), at pp.4-5.

368 P.115-117, Brett L. Billet, Modernization Theory and Economic Development: Discontent in the Developing World (1993). 
widespread "discontent" with modernization theory in the developing world. ${ }^{369}$ Inflows of foreign direct investment correlate with higher levels of external debt, official aid and military assistance, suggesting that a "client-state" relationship of sorts may be necessary to attract and support these inflows. ${ }^{370}$

In the context of "Washington-consensus" structural adjustments such as privatization, for example, private foreign direct investment in privatized state assets often floats on a wide range of support from interested governments (e.g., the political risk insurance provided by the U.S. to its nationals through OPIC) and international organizations (e.g., the loan guarantees provided by the IMF to such investors through MIGA). Such supports enable foreign direct investment to occur but are also accompanied by formal ${ }^{371}$ and informal ${ }^{372}$ conditionalities shaping the policies and terms structuring such investment. are [support with dissection of privatization relationship and IMF guarantees] This clustering effect of ties to foreign economies may produce the experience of impaired sovereignty that Rittich, for example, has observed as a critique of good governance reforms. ${ }^{373}$

The "capitalist nucleus" dynamic appears to operate on an even more fundamental bias, that of the size of the host economy: such capital inflows tends to favor economies that already have some minimal level of capital formation.

369 Pp.117-122, Brett L. Billet, Modernization Theory and Economic Development: Discontent in the Developing World (1993).

370 Pp.117-122, Brett L. Billet, Modernization Theory and Economic Development: Discontent in the Developing World (1993).

371 The policy of conditionality.

372 Technical assistance and advice. See, e.g., Rittich, The Future of Law and Development, 26 Mich. J. Int'1 L. 199, 206 (2004) (describing both conditionality and a "variety of other soft mechanisms to promote the reforms that they regarded as optimal... from technical advice...; thematic reports and policy prescriptions...; and empirical research.").

373 Pp.210-211 \& 231-232, Rittich, The Future of Law and Development, 26 Mich. J. Int'1 L. 199 (2004). 
Consequently, those countries "that have the greatest need for external capital sources due to their relatively lesser ability to generate capital domestically are the most unlikely to obtain" it. ${ }^{374}$ According to one analyst, Bret Billet in a 1993 study, the beneficiaries from this "circle of prosperity" are relatively few. ${ }^{375}$ Consequently, modernization-theorybased measures such as structural adjustment and associated good governance reforms may serve to "enlarge the gap between the richest and the poorest" of countries. 376

If only a relative difference in economic growth, an enlarging gap need not undermine the case for Washingtonconsensus reform. Where the gap reflects an absolute decline, as apparently characterizes some countries, the cause for concern becomes much greater. 377

There are a number of flaws in good governance lending. The first is the methodology of how "good governance" is computed. For example, the World Bank relies too much on opinion surveys, allowing for the possibility that subjective impressions - and biases -- are reproduced in assessment criteria. [cite Kaufman study] More disturbing from the perspective of good governance advocates is the suggestion of recent empirical data compiled by Eric Neumayer that funding appears to track "donor interest" - as measured, for example, by the export interest of donor-country nationals and by political ties, ${ }^{378}$ at

374 Pp.121, Brett L. Billet, Modernization Theory and Economic Development: Discontent in the Developing World (1993).

375 Pp.121, Brett L. Billet, Modernization Theory and Economic Development: Discontent in the Developing World (1993).

376 Pp.122, Brett L. Billet, Modernization Theory and Economic Development: Discontent in the Developing World (1993).

377 See Chantal Thomas, Am U ILR discussion of relative versus absolute inequality amongst countries, noting that some Eastern European countries and sub-Saharan African countries have experienced an absolute decline in some income and quality of life indicators.

${ }^{378}$ Neumayer, at pp.97 (concluding that although "recipient need" as measured by poverty levels proved significant in determining "aid eligibility," donor interests such as "colonial experience" and "economic interests in the form of 
least as much as "good governance" criteria such as adherence to the rule of law or low levels of corruption. ${ }^{379}$ The same study found that, of all the potential criteria for measuring good governance, "low regulatory burden" proved to be the only consistently significant correlative to aid levels. ${ }^{380}$

Despite the nominal value assigned to democracy and respect for human rights, these factors were, by contrast, indeterminate or insignificant in determining aid levels. 381 These empirical findings seem to support similar conclusions from Billet's study of a decade earlier that political and economic interests "cluster" around and ultimately drive such programs. They also support the intuition voiced by critics of good governance that marketoriented reforms continue to trump democratic reforms, notwithstanding the formal inclusion of the latter in contemporary good governance assessments. ${ }^{382}$ Finally, such findings underscore the general concern that recipient countries continue to be rewarded for implementing "one size fits all" economic policies, rather than for adopting more specific institutional reforms related to participatory and non-corrupt decision-making. ${ }^{383}$

exports and military-strategic interests" proved more significant in determining the level of "good governance" aid).

379 Neumayer found that "[1] ow corruption and respect for the rule of law are basically irrelevant" in determining good governance aid flows. Neumayer at p.82.

380 p.97 Neumayer.

381 P.97 Neumayer (finding that such criteria determined initial aid eligibility but not aid levels).

382 See Thomas, Does Good Governance Privilege Markets at the Expense of Democracy?; Rittich, The Future of Law and Development at 224-225.

383 Rittich, The Future of Law and Development, at 224-225 ("Although one of the touchstones of second generation reforms is the rejection of a one-size-fits-all template for development and the importance of wider participation in the formulation of development goals, there is surprisingly little diversity in either the discourse or the prescriptions about the legal reforms needed for development.") 
Theoretical Shortcut \#3: The Correlation Between Modern Capitalism and Democracy.

Although good governance reforms have recently begun to emphasize the importance of participation by civil society, some Good Governance Scholars have observed that much remains in the way of implementation. ${ }^{384}$ Good governance programs too often maintain a dual and selfreinforcing narrowness of focus: substantively on promoting the interests of the investors as opposed to other stakeholders in economic growth; and institutionally in maintaining a top-down, "one-size-fits-all" approach. The preceding two sections suggested that these two shortcomings flow from the Theoretical Shortcuts intrinsic to the analytical framework supporting good governance policy. This section argues that the dangers that flow from this self-reinforcing narrowness are insufficiently perceived due to an overly casual assumption about the natural correlation between modern bureaucracy, capitalism, and democracy. ${ }^{385}$

A striking example of this would be the World Bank's recent experiences with privatization of water utilities in Latin America, and especially in Cochabamba, Bolivia. The strategy implemented a "one-size-fits-all" program of privatization rooted in the Washington consensus. ${ }^{386}$ The focus of such programs has ostensibly been to improve water delivery in poor countries, reducing the inefficiency of existing government utilities and advancing progress towards the Millennium Development Goal of improved access to potable water.

In practice, however, the privatizations often focused

\footnotetext{
384 See, e.g., Rittich, supra.

385 Amy Chua has made this point with respect to the rights of ethnic minorities in developing economies, in her book World on Fire.

${ }^{386}$ See, e.g., World Bank, Strategic Directions for World Bank Engagement (2003); World Bank, Water Resources Management (1993).
} 
on protecting the interests of investors, to the (perhaps unintended) exclusion of other stakeholders and especially of consumers. Thus, the World Bank was able to employ its formidable resources to offer political risk guarantees and below-market loans to make such privatizations attractive for investors.

From the modernization-cum-good-governance perspective, such a program may not have raised red flags because of the policy shortcomings that arise from the Theoretical Shortcuts. First, privatization was accepted as a universally desirable and effective legal reform. Second, an emphasis may have been placed on the interests of investors over other stakeholders on the theory that this emphasis would unleash the "capitalistic spirit" necessary to trigger economic growth. Finally, no deliberate assessment of the role of democratic participation was made, perhaps because of an insufficient sensitivity to the role of power and coercion in modern bureaucratic governance.

Had local consumers been consulted in advance, an awareness of the implausibility of the Bolivia privatization might have surfaced. Proponents might have realized that the projected prices for privatized water services far exceeded the price points at which consumers were willing to pay, particularly those for whom the new water service would require a third or more of their monthly salaries. 387 Moreover, proponents might have realized that land claims to local water sources were contested. Because none of these assessments were made, the Bolivia water privatization proceeded as planned but soon encountered radical resistance on the part of the local population, leading to the cancellation of the privatization contract and embroiling the Bank in controversy. Unfortunately, the experience with Bolivia resembles those of other recent water privatizations

${ }^{387}$ Public Citizen, Water Privatization Fiascoes: Broken Promises and Social Turmoil (2003). 
throughout the developing world. ${ }^{388}$

The disastrous experience with water privatizations indicates the danger of insufficiently incorporating local participation and local information into the development policymaking process. Recently, good governance policy has sought to correct this imbalance by explicitly incorporating "civil society." Good Governance Scholars such as Kerry Rittich, have argued that such recent reforms have taken place more on the surface than in practice. 389

\section{PART III. Conclusions and Prospects For Reform}

David Ellerman, a former World Bank economist, has sought to incorporate many of these insights into a new approach to development policy, which he entitles "Autonomy Respecting Development." Ellerman has argued that "social engineering" approaches to development are destined to fail: "problems in the social engineering approach are endemic. Sustainable transformation towards developmental ends needs to be based on motives that come out of the doers' own internal values - and knowledge needs to be grounded on the doers' own learning experiences." 390

Following the observations related to the three Theoretical Shortcuts, such "autonomy-respecting development" should: (1) avoid the "one-size-fits-all" approach by carefully considering local context; (2) avoid the "determinism of values" by eschewing implicit cultural imperialism, understanding the role of material conditions and "nonnormative interest" in affecting outcomes, and balancing the interests of investors with those of other

\footnotetext{
${ }^{388}$ Id.

${ }^{389}$ Rittich, The Future of Law and Development, 26 Mich. J. Int'1 L. 199 (2004).

390 Ellerman, Autonomy-Respecting Development.
} 
stakeholders; and (3) incorporate an awareness of the role of coercion in modern governance, and the non-automaticity of democracy therein, by specifically seeking out local participation.

Good governance reforms are already moving in this direction. Policy documents by the World Bank increasingly emphasize the importance of context and local capacitybuilding. They also recognize the importance of engaging economic groups beyond investors. Finally, they have moved towards institutionalizing more participatory decision-making.

The World Bank Inspection Panel exemplifies all three kinds of insights. The Inspection Panel allows local groups to identify specific grievances relating to World Bank sponsored development projects. The Panel could be better institutionalized, however; currently it is ad hoc, dependent on a petition rather than an automatic part of the process; it frequently occurs after the development project has already been completed; and it often serves only an advisory function. Improvements would come from including this kind of information-gathering as an automatic and central part of the formulation of local development projects.

The solutions offered by Ellerman, the Inspection Panel, and the Good Governance Scholars will be noticeably more redistributive (or at least multi-distributive) than the policies offered by the Rostovians and Parsonians.

Ultimately, the proposed differences in distributional consequences cannot escape an underlying debate on political economy. There simply is a difference of opinion about the relative value of participatory, redistributive development policy, and therefore about the relative values of legal reforms designed towards that end.

Moreover, all of these approaches disregard sovereignty, in the traditional sense of the term to mean the recognition of a unitary, unconstrained state. In different 
ways, all of these approaches situate themselves within a contemporary "global governance" framework, in which law and policy arises out of the interaction between multiple institutional and social planes.

Finally, these suggested reforms do not necessarily reflect what Weber himself might have recommended, if he were writing on international political economy today. Rather, they represent an attempt to put "Weberian wheels" back on the right track in law and development. ${ }^{391}$

391 See Duncan Kennedy, The Disenchantement of Logically Formal Rationality, or Max Weber's Sociology of Law in the Geneaology of the Contemporary Mode of Western Legal Thought, supra, at 1076. 